\title{
Fatores associados à elevada densidade mineral óssea em mulheres
}

Karin Sedó Sarkis

Tese apresentada ao Programa de PósGraduação em Nutrição em Saúde Pública para obtenção do título de Doutor em Ciências.

Área de Concentração: Nutrição em Saúde Pública

Orientadora: Profa. Dra. Lígia A. Martini

São Paulo

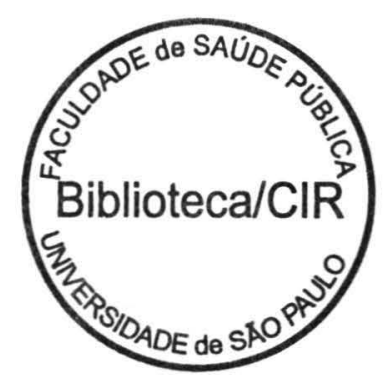

2012 
É expressamente proibida a comercialização deste documento, tanto na sua forma impressa como eletrônica. Sua reprodução total ou parcial é permitida Exclusivamente para fins acadêmicos e científicos, desde que na reprodução figure a identificação do autor, título, instituição e ano da tese.

$$
53880 / 2012
$$




\section{Dedico esta tese}

Aos meus avós in memorium, sempre presentes em meu coração.

Aos meus pais, pessoas maravilhosas que me acompanham em todos os momentos com um amor incondicional. $\mathcal{E} u$ amo vocês!

A minha orientadora, Dra. Lígia Araújo Martini, que apesar de me achar "desgarrada" sempre me acolhe. Obrigada por acreditar! 


\section{AGRADECIMENTOS}

$\mathcal{A}$ Deus por estar sempre presente em minha vida.

Ao Dr. Marcelo de Medeiros Pinheiro por ser a pessoa maravilhosa que é. Graf̧as a isto trabalhar ao seu lado é extremamente prazeroso. Obrigada pela constante paciência e por todo o aprendizado!

A Dra. Vera Lúcia Szejnfeld que me recebeu em seu grupo de doenças ósteo-metabóficas e a todos que fazem parte do grupo: Aurora, Beatriz, Dani, Fabio, Henrique, Marina, Grafa e um agradecimento especial ao Charles, te admiro demais!

À professora Dra. Nágila Damasceno por sempre ter me acolfido com muito carinho e pelo exemplo de dedicação.

Ao Valdecir pela paciência nas explicą̧ões das análises.

As colegas de pós-graduação Bárbara, Natielen, Patrícia e Vivian.

Ao Paulo, pelo constante incentivo, companheirismo e por me mostrar o valor de tudo que faço.

As amigas das diversas fases da vida que me acompanham desde a infância Maria do Carmo, adolescência: Analu, Marcela e Suzy; vida adulta: Alessandra, Alice, Ana Paula G Silva, Ana Paula Q. Mello, Andrea, Carla, Cinthia, Isis, Sara, Vanessa e Vivianne que a lista continue a aumentar. Amizade é a melhor coisa do mundo!

As mulheres maravilhosas que me ajudaram na coleta de dados: Luzia, Neusa e Tereza. Vocês foram extremamente importantes neste trabalho! 
Aos funcionários do Departamento de Nutrição da Faculdade de Saúde Pública- USP e aos funcionários da Disciplina de Reumatologia da UNIFESP por todo auxilio prestado.

Finalmente, as mulferes que gentilmente participaram deste estudo.

\section{Muito obrigada!}


"O fato é que ciência e sabedoria são coisas muito diferentes. Ciência é conhecimento do mundo. Sabedoria é confecimento da vida."

Rubem Alves

Acredito que o verdadeiro cientista deva associar a exuberância do confecimento científico à grandiosidade da sabedoria. 


\section{RESUMO}

Sarkis KS. Fatores associados à elevada densidade mineral óssea em mulheres [tese de doutorado]. São Paulo: Faculdade de Saúde Pública; 2012.

Introdução: Vários parâmetros estão associados com alta densidade mineral óssea (DMO), como obesidade, etnia negra, atividade física intensa, padrão alimentar e alguns medicamentos. Objetivos: avaliar a prevalência e os principais aspectos associados com a DMO elevada em mulheres saudáveis. Métodos: Em revisão do banco de dados de DMO realizadas na área metropolitana de São Paulo, a alta DMO (acima de $1400 \mathrm{~g} / \mathrm{cm}^{2}$ em coluna lombar e / ou acima de $1200 \mathrm{~g} / \mathrm{cm}^{2}$ em colo do fêmur) foi encontrada em 421 exames de um total de 21000 exames avaliados. Após os critérios de exclusão permaneceram no estudo 40 mulheres com DMO elevada e pareadas com 40 mulheres com DMO normal, para cor de pele, peso, idade e estado menopausal. A história médica, a ingestão de alimentos e AF foram avaliadas por meio de questionários validados. Para a avaliação do padrão alimentar os alimentos foram agrupados segundo a semelhança nutricional. A composição corporal foi avaliada por meio de densitometria óssea com raio X duo-energético (DXA - GE Lunar Radiation Corporation, model DPX, Madison, WI, USA). Radiografia da coluna torácica e lombar foram realizadas para excluir alterações degenerativas ou fraturas. Os parâmetros bioquímicos incluíram tanto os perfis hormonais e lipídicos, como marcadores bioquímicos do metabolismo mineral e ósseo. A análise estatística incluiu testes paramétricos e não paramétricos, modelos de regressão linear e análise fatorial. $\mathrm{P}<0.05$ foi considerado significante. Resultados: A idade média foi de 50.9 (8.3) anos. Houve diferença significante entre os grupos em relação à massa magra (massa magra total, p=0.029 e massa magra apendicular, $\mathrm{p}=0.007$ ), sendo maior no grupo com DMO elevada, e em relação ao Ctelopeptídeo de colágeno tipo I (CTX), que foi inferior no grupo DMO elevada ( $\mathrm{p}=$ 0.04). No modelo final de regressão multivariada, a menor ingestão de gordura e gordura corporal, bem como menor concentração de LDL-colesterol previu aproximadamente $35 \%$ da DMO elevada nas mulheres (R2 ajustado $=0.347, \mathrm{p}<0.001)$. Além disso, maiores quantidades de massa magra e concentrações séricas de IGF-1 exerceram papel de proteção, independente da idade e peso. Com relação ao padrão dietético, as mulheres com DMO elevada apresentaram uma dieta saudável com baixo consumo de carnes processadas. Conclusão: Os resultados demonstram o potencial 
efeito deletério de componentes relacionados ao metabolismo lipídico como a ingestão de gordura e gordura corporal e maior concentração de LDL sobre a massa óssea e metabolismo em mulheres com DMO elevada além de evidenciar que as mulheres com elevada DMO apresentam alimentação mais saudável em relação ao grupo controle avaliado.

Descritores: Densidade mineral óssea, Composição corporal, Metabolismo lipídico, Dieta, Metabolismo mineral, Mulheres e Padrão alimentar 


\begin{abstract}
Sarkis SK. Factors associated with high bone mineral density in Brazilian women [thesis]. São Paulo: Faculdade de Saúde Pública; 2012.
\end{abstract}

Introduction: Several factors are associated with high bone mineral density (BMD), such as overweight, race (african descendent), intense physical activity (PA), dietary patterns and some medications. Objectives: the aim of the study was to evaluate the prevalence and the main aspects associated with high BMD in healthy women. Methods: Considering data on BMD from the São Paulo metropolitan area database, the high BMD (over $1400 \mathrm{~g} / \mathrm{cm}^{2}$ at lumbar spine and/or above $1200 \mathrm{~g} / \mathrm{cm}^{2}$ at femoral neck) was found in 421 exams. After the exclusion criteria, 40 women in the study remained with high BMD compared to 40 healthy women with normal BMD, paired together in relation to weight, age, skin color and menopausal status. Medical history, food intake and PA were assessed through validated questionnaires. Foods were systematically grouped together on the basis of similarities of food and nutrient composition and entered into factor analysis. Body composition was evaluated through a DXA (GE Lunar Radiation Corporation, model DPX, Madison, WI, USA). Radiography of the thoracic and lumbar spine was carried out to exclude degenerative alterations or fractures. Biochemical parameters included both lipid and hormonal profiles, along with mineral and bone metabolism. Statistical analysis included parametric and nonparametric tests, linear regression models and factor analysis. $P<$ 0.05 was considered significant. Results: The mean age was 50.9 (8.3) years. There were significant differences between groups in relation to lean body mass (total fat-free mass, $\mathrm{p}=0.029$ and appendicular lean mass, $\mathrm{p}=0.007$ ), being higher in women with high BMD and serum C-telopeptide of type I collagen (CTX), and was lower in the high BMD group $(p=0.04)$. In the final model of multivariate regression, a lower fat intake and body fatness as well as a lower concentration of LDL-cholesterol predicted almost $35 \%$ of high BMD in women, (adjusted R2 $=0.347 ; p<0.001$ ). In regards to dietary patterns, women with high BMD showed a healthy diet with low consumption of processed meats. Conclusion: Our results demonstrated the deleterious potential effect of lipid metabolism-related components including fat intake, body fat and higher lipid profile on bone mass and metabolism in women with high $\mathrm{BMD}$, along with showing that women with high BMD have a healthier diet. 
Descriptors: Bone mineral density, Body composition, Lipid metabolism, Diet, Mineral metabolism, Women, Dietary Pattern 


\section{ÍNDICE}

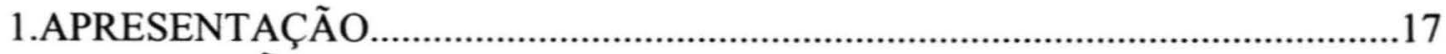

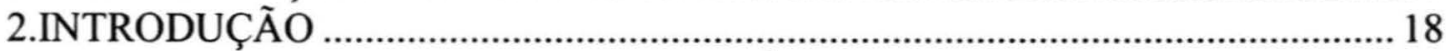

2.1 ELEVADA DENSIDADE MINERAL ÓSSEA …………………………….... 18

2.2 ANTROPOMETRIA E COMPOSIÇÃO CORPORAL ……………………....... 19

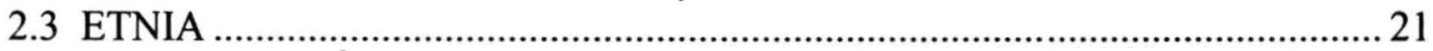

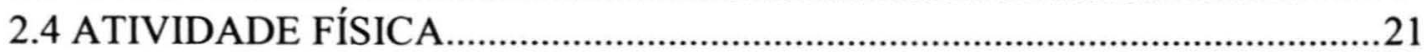

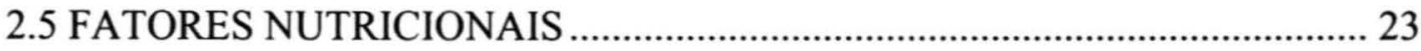

2.5.1 Proteína

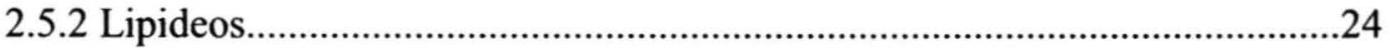

2.5.3 Cálcio e Vitamina D ..........................................................................23

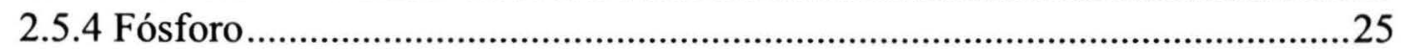

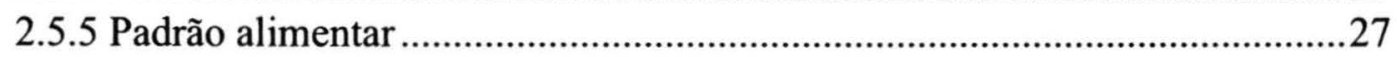

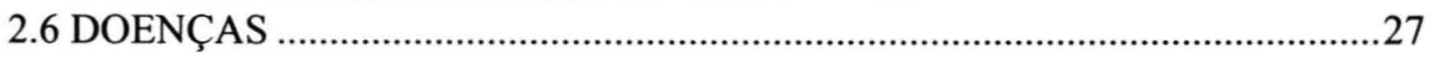

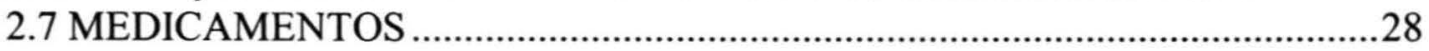

2.8 PERFIL HORMONAL ...............................................................................

2.8.1 Vitamina D e Paratormônio .........................................................................30

2.8.2 Hormônios sexuais ................................................................................

2.9 PERFIL LIPÍDICO _.......................................................................................

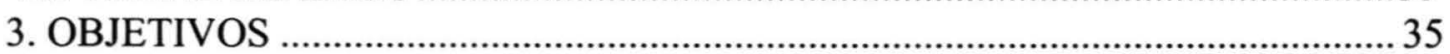

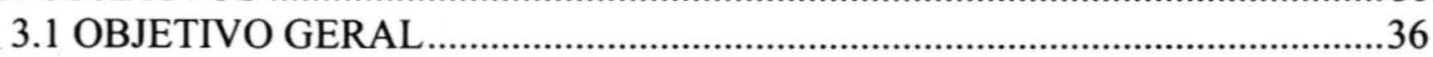

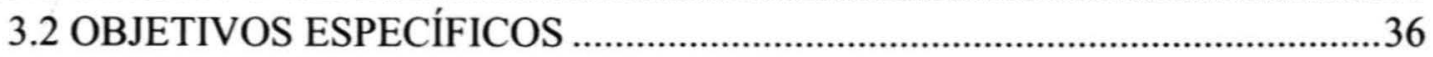

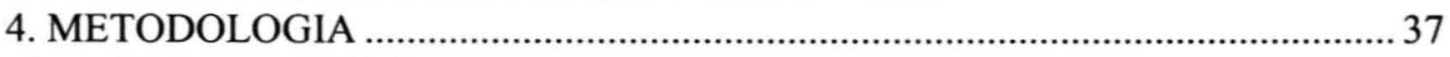

4.1 DELINEAMENTO......................................................................................

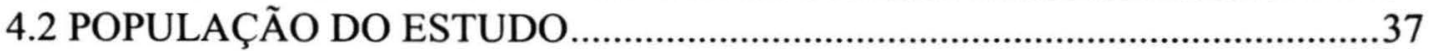

4.2.1 Cálculo do tamanho amostral ..................................................................38

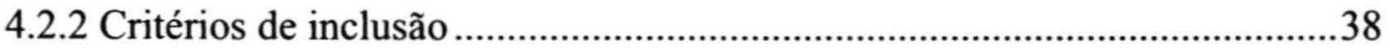

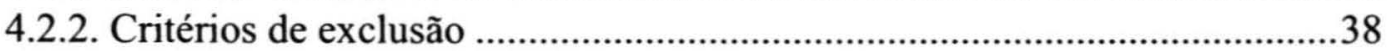

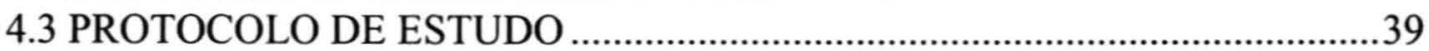

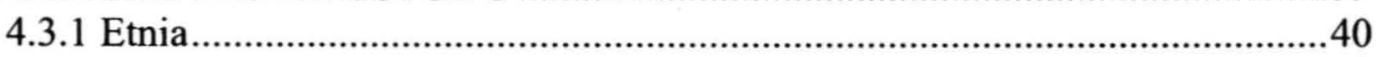

4.3.2 Avaliação antropométrica .........................................................................40

4.3.3 Avaliação radiológica: .............................................................................

4.3.4 Avaliação da Densidade Mineral Óssea :....................................................41

4.3.5 Avaliação da composição corporal ..............................................................42

4.3.6 Parâmetros bioquímicos ............................................................................4

4.3.7 Avaliação dos fatores relacionados à massa óssea ………………………....44

4.3.8 Avaliação do Consumo Alimentar ...............................................................44

4.3.9 Avaliação da Atividade Física .......................................................................46

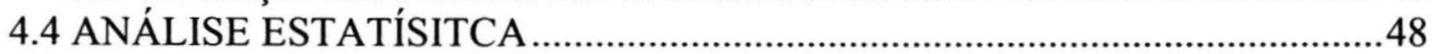

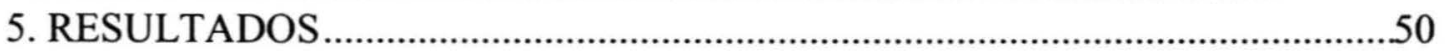

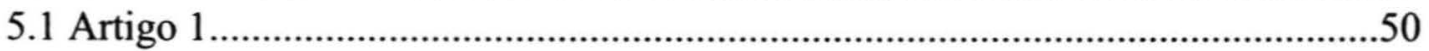

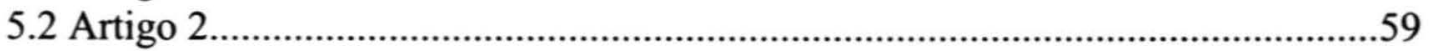

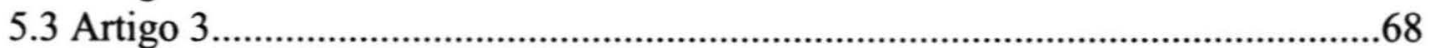

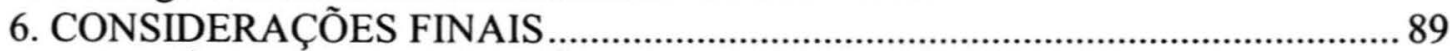

7. REFERÊNCIAS BIBLIOGRÁFICAS ............................................................ 90

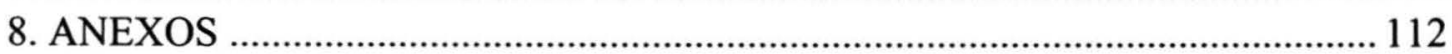

Anexo I - Termo de concentimento livre e esclarecido 
Anexo II- Questionário sobre fatores de risco da massa óssea Anexo III- Questionário de Frequência Alimentar

Anexo IV- Questionário sobre atividade fisica

Anexo V - Aprovação do comitê de ética 


\section{LISTA DE TABELAS E FIGURAS}

\section{Artigo 1}

Table 1. Modifiable risk and protection factors and physiopathogenic mechanisms proposed to explain the association between high bone density and bone health

\section{Artigo 2}

Table 1. Anthropometric, clinical and nutritional data of the population, according to BMD

Table 2. Metabolic, hormonal and biochemical parameters of the metabolism bone and mineral of the population study, according BMD

Table 3. Final model of multivariable regression using equations to estimate HBMD in women

\section{Artigo 3}

Table 1: Anthropometric, clinical and body data of the population, according to BMD

Table 2: The five components (dietary patterns) identified from the food frequency questionnaires using factor analysis in HBMD

Table 3: The five components (dietary patterns) identified from the food frequency questionnaires using factor analysis in healthy controls 


\section{LISTA DE ABREVIATURAS, SIGLAS E SÍMBOLOS}

\begin{tabular}{|c|c|}
\hline $25(\mathrm{OH}) \mathrm{D3}$ & Calcidiol \\
\hline$A C S M$ & American College Sports of Medicine \\
\hline ANOVA & Análise de variância \\
\hline$B R A Z O S$ & Brazilian Osteoporosis Study \\
\hline$B M D$ & Bone Mineral Density \\
\hline$B M I$ & Body mass index \\
\hline COEP & Comitê de ética em pesquisa \\
\hline$C T X$ & Telopeptídeo carboxiterminal do colágeno tipo I \\
\hline DMO & Densidade Mineral Óssea \\
\hline DP & Desvio padrão \\
\hline DRIs & Dietary Reference Intake \\
\hline DXA & Dual energy x-ray absorptiometry \\
\hline EDMO & Elevada Densidade Mineral Óssea \\
\hline FFQ & Food Frequency Questionnaire \\
\hline FIFI & Fundação Instituto de Diagnóstico por Imagem \\
\hline FSH & Hormônio folículo estimulante \\
\hline FSP & Faculdade de Saúde Pública \\
\hline GH & Hormônio do crescimento \\
\hline GnRH & Hormônio liberador de gonadotrofina \\
\hline HBD & High bone density \\
\hline IGFBP-1 & Proteína 1 de ligação ao fator de crescimento semelhante à insulina \\
\hline IGF-1 & Fator de crescimento semelhante a insulina \\
\hline IL-6 & Interlecina -6 \\
\hline IMC & Índice de Massa Corporal \\
\hline IOM & Institute of Medicine \\
\hline LH & Hormônio luteinizante \\
\hline NTX & N-telopeptídeo do colágeno tipo I \\
\hline OMS & Organização Mundial da Saúde \\
\hline OP & Osteoprotegerina \\
\hline P1NP & N-terminal propeptideo de procolágeno tipo 1 \\
\hline PC & Principal Component \\
\hline
\end{tabular}




$\begin{array}{ll}\text { PTH } & \text { Paratormônio } \\ \text { rhPTH 1-34 } & \text { PTH recombinante humano 1-34 (teriparatida) } \\ \text { QFA } & \text { Questionário de Frequência alimentar } \\ \text { RANK } & \text { Receptor do Ativador Nuclear K } \beta \\ \text { RANK-L } & \text { Ligante do Receptor do Ativador Nuclear K } \beta \\ \text { ROI } & \text { Oxigênio Intermediário Reativo } \\ \text { ROS } & \text { Espécies reativas de oxigênio } \\ \text { SHBG } & \text { Globulina ligadora dos hormônios sexuais } \\ \text { SPSS } & \text { Statistical Package for the Social Sciences } \\ \text { TNF- } \alpha & \text { Fator de necrose tumoral alfa } \\ \text { USP } & \text { Universidade de São Paulo } \\ \% & \text { Porcentagem } \\ > & \text { Maior } \\ < & \text { Menor } \\ \geq & \text { Maior ou igual } \\ \leq & \text { Menor ou igual } \\ \mu & \text { Micro }\end{array}$




\section{APRESENTAÇÃO}

Esta tese inicia-se com a seção de introdução, seguida dos objetivos, metodologia, resultados, considerações finais e, por fim, dos anexos. Na seção de resultados encontram-se três artigos, sendo dois aceitos para publicação e um a ser submetido ao periódico para a publicação. O primeiro manuscrito é uma revisão da literatura e os dois últimos são compostos dos seguintes tópicos: introdução, metodologia, resultados, discussão, referências bibliográficas, tabelas e gráficos. 


\section{INTRODUÇÃO}

\subsection{ELEVADA DENSIDADE MINERAL ÓSSEA}

A ocorrência de Elevada Densidade Mineral Óssea (EDMO) tem sido descrita na literatura na última década. Porém, como a maioria dos estudos investiga indivíduos com baixa Densidade Mineral Óssea (DMO), os critérios diagnósticos para osteoporose já estão bem estabelecidos pela Organização Mundial da Saúde (OMS, 1994), mas o mesmo não ocorre com a EDMO.

Em relação à mensuração da $\mathrm{DMO}$, realizada pela densitometria óssea com raio $\mathrm{X}$ duo-energético (DXA), os indivíduos que apresentam valores de T-score igual ou acima de -1 desvio padrão (DP) são classificados com massa óssea normal; já, indivíduos abaixo deste valor são classificados como tendo osteopenia (T-score entre -1.0DP e -2.5DP) ou osteoporose (T-score igual ou menor que -2.5DP), dependendo do valor do T-score. Esta classificação é reconhecidamente aceita, porém não há um valor de T-score limítrofe para a classificação da massa óssea acima do normal (WHO, 1994; ISCD, 2006; NOF, 2008).

Partindo do pressuposto de que valores de T-score menores ou iguais a -2.0 DP indicam baixa densidade óssea e um maior risco de fratura, seria aceitável a utilização de valor de T-score $2.0 \mathrm{DP}$ como ponto de corte para classificar a massa óssea acima do normal.

Apesar de não haver um ponto de corte consensual para EDMO, estudo de coorte realizado por PESONEM e cols. (2005), com mais de 1800 mulheres, sugere que o ponto de corte para elevada DMO seja de $1,209 \mathrm{~g} / \mathrm{cm}^{2}$ para o colo do fêmur e $1,228 \mathrm{~g} / \mathrm{cm}^{2}$ para a coluna lombar (quartis superiores). Avaliando mais de $96 \mathrm{mil}$ exames de densitometria óssea, GREGSON e cols. (2009), definiram valores de Zescore, igual ou maior do que 3,5DP para a coluna vertebral e / ou colo do fêmur para a caracterização de tais indivíduos; com base neste critério, apenas 169 indivíduos com alta densidade óssea foram encontrados (aproximadamente $0,2 \%$ do total amostra).

Poucos estudos abordam a prevalência ou os principais aspectos clínicos e laboratoriais de indivíduos com EDMO. No entanto, a maioria deles aponta que peso elevado (ORXOLL e cols., 2000) e índice de massa corpórea (IMC) acima de 30 
kg/m² (WHYTE, 1997; ORXOLL e cols., 2000; CHEN e cols., 2002), fatores genéticos como mutações no gene da proteína 5 relacionada com o receptor do LDL - LRP5 (WHO, 1998; VAN WESENBEECK e cols., 2003; CUI e cols., 2011), sexo masculino, etnia negra (BELL, 1997), atividade fisica regular (LORD e cols., 1996.; SILMAN e cols., 1997), ingestão elevada de cálcio (acima de $1500 \mathrm{mg} / \mathrm{dia}$ ) (HEANEY e cols., 1978; HEANEY e cols., 1989; KANIS,1989), assim como o uso de medicações como estatinas (PASCO e cols., 2002; CHUENGSAMARN e cols. 2010) e diuréticos tiazídicos (TANAKA e cols., 2001; KAMEL, 2002; OLMOS e cols., 2010 ) parecem exercer influência positiva sobre a densidade óssea.

Além disso, sabe-se que indivíduos obesos; pacientes com câncer de mama e endométrio, com receptor estrogênico positivo (CAULEY e cols., 1996; CHEN e cols., 2008; GREINER e cols., 2010); diabéticos tipo II (WHYTE e cols., 2000; MA e cols.,2012) e atletas (ALFREDSON e cols., 1996; ALFREDSON e cols., 1998; TRUTSCHNIGG e cols., 2008) apresentam maior densidade óssea do que indivíduos saudáveis; porém, os fatores determinantes da EDMO ainda não estão bem estabelecidos (WHYTE, 1997; PESONEM e cols., 2005).

Outro ponto obscuro se deve ao risco de fraturas. Não se sabe se indivíduos com EDMO apresentam menor risco de fratura, já que tais valores de DMO podem associar-se a uma diminuição da resistência mineral óssea, uma vez que EDMO pode não estar relacionada à resistência óssea (CHAVASSIEUX e col, 2007).

A seguir serão descritos os principais fatores não genéticos que interferem na DMO

\subsection{ANTROPOMETRIA E COMPOSIÇÃO CORPORAL}

Os mecanismos relacionados ao aumento da DMO advindos dos fatores antropométricos e composição corporal ainda não estão totalmente elucidados, porém, sugere-se que valores de Índice de Massa Corporal (IMC) representem uma importante proporção na variação da DMO (8,9 - 19,8\%) (FELSON e cols., 1993; REID, 2002).

MORIN e LESLIE (2009), em estudo de coorte retrospectivo realizado em 16.500 mulheres acima de 50 anos, relatam ser incomum mulheres com EDMO 
$(0,9 \%)$, no entanto, uma maior frequência $(43,5 \%)$ foi observada nas que apresentam valores de IMC acima de $30 \mathrm{~kg} / \mathrm{m}^{2}$, indicando uma forte correlação entre EDMO e elevados valores de IMC.

O IMC indica a adequação do peso do indivíduo (em $\mathrm{kg}$ ) para a sua altura (em metros quadrados) (OMS, 1995), assim, a avaliação realizada pelo IMC restringe-se ao peso de uma maneira geral não havendo diferenciação entre seus componentes: massa magra e massa gorda (LEKAMWASAM e cols., 2009).

Estudos mostram que, além do peso, a massa magra e massa gorda apresentam impacto sobre o osso de maneiras distintas (TAKADA e col, 1997; ILICH e cols., 2002; GINTY, 2005; REID e cols., 2006; REID e cols., 2008; PARK e cols., 2012; LEE, 2012).

$\mathrm{O}$ aumento da massa magra ocasiona aumento da força muscular e, assim, estimula o remodelamento ósseo por meio do efeito do estresse mecânico (TAKADA e col, 1997). Este efeito parece ser decorrente da ação direta da "carga mecânica" sobre o osso exercido pela força e massa muscular, estimulando o esqueleto (ILICH e col, 2002). De acordo com a maioria dos autores, representa o principal determinante da densidade óssea (ILCHI e cols. 2002; GENARO e cols., 2009; PARK e cols., 2012; LEE, 2012).

A massa adiposa contribui de modo menos relevante. Especula-se que um dos principais mecanismos fisiopatológicos se deva ao aumento das concentrações séricas de leptina, hormônio secretado pelos adipócitos, que parece agir de forma direta no esqueleto, regulando o desenvolvimento dos osteoclastos, reduzindo a produção de Receptor do Ativador Nuclear K $\beta$ (RANK) e do Ligante do Receptor do Ativador Nuclear K $\beta$ (RANK-L), aumentando a Osteoprotegerina (OP) e resultando em uma inibição da osteoclastogênese. Sua atuação também ocorre de maneira central, via hipotálamo, porém, esta ação, ao contrário da descrita anteriormente, suprime a formação óssea (BORBA e cols., 2003; REID e cols., 2006; REID, 2008).

Além disso, em obesos, ocorre aumento da secreção de hormônios pancreáticos (insulina, preptina e amilina), que atuam positivamente sobre o tecido ósseo. A condição hiperinsulinêmica, associada à maior quantidade de tecido adiposo, resulta em algumas anormalidades, tais como, elevada produção ovariana de estrogênios e reduzida síntese hepática de proteínas ligantes de hormônios sexuais. A 
amilina é secretada juntamente com a insulina e inibe a reabsorção óssea, enquanto a preptina aumenta a atividade dos osteoblastos, especialmente em obesos (REID, 2008).

Outro hormônio envolvido é a grelina, sintetizada em sua maior parte no estômago. Há evidências de que seu efeito no tecido ósseo seja duplo: os receptores encontram-se nos osteoblastos que agem estimulando a proliferação e diferenciação dos mesmos (FUKUSHIMA e cols., 2005; MACCARINELLI e cols., 2005), porém, apresenta ação na osteoclastogênese acompanhada de jejum. Os resultados em humanos ainda são contraditórios (REID, 2008).

\subsection{ETNIA}

Mulheres negras apresentam maior densidade mineral óssea quando comparadas com as brancas (ALOIA e cols.,1999), principalmente em sítios como o colo do fêmur e quadril (CHANTLER e cols., 2012). A maior reabsorção renal de cálcio e resistência à ação reabsortiva do PTH é um dos principais mecanismos propostos (KLEEREKOPER e cols., 1994). Além disso, a maior massa muscular das negras, devido à maior modulação muscular por tração (força biomecânica), também deve ser considerada, resultando em menor risco de fraturas em ambos os sexos (BARON e cols., 1994; LAUDERDALE e cols., 1998; JACOBSEN e cols., 1992; HEANEY, 1995).

\subsection{ATIVIDADE FÍSICA}

Os benefícios da atividade física para a massa óssea têm sido amplamente reconhecidos (MARCUS, 1998). Os prováveis mecanismos envolvem a contração muscular, que proporciona um aumento das fibras musculares e contribui para o aumento da massa óssea (MATSUDO, e cols. 2000). O impacto proporcionado pelo exercício na massa óssea, gerando uma resposta osteogênica mecânica adaptativa; liberação de hormônios anabólicos, como o hormônio do crescimento (GH), fator de crescimento semelhante a insulina (IGF-1), estrógeno e o paratormônio (PTH), que promovem sinais para a resposta osteogênica (BORER, 2005). Adicionalmente, o 
efeito piezoelétrico, explicado pelas ações mecânicas que geram diferenças no potencial elétrico dos ossos, e agem como um campo elétrico, estimula a atividade celular, levando à deposição de minerais nos pontos de estresse (LANYON e HARTMAN apud CADORE e cols., 2005).

Esses aspectos são demonstrados em estudos onde há incremento de marcadores de formação óssea, como da osteocalcina e do P1NP, decorrentes da atividade física (ADAMI e cols., 2008) e em maior densidade óssea em atletas de modalidades esportivas de alta intensidade, resistência e impacto, (ALFREDSON e cols., 1996; ALFREDSON e cols., 1998; TRUTSCHNIGG e cols., 2008, MORGAN e cols., 2011).

Em mulheres na pré e pós-menopausa há resultados contraditórios, de acordo com o tipo de treinamento utilizado. (BASSEY e cols., 1998).

WALLACE e CUMMING (2000), em artigo de revisão, demonstram efeitos positivos da atividade física (exercícios com e sem impacto, em especial corrida e musculação, respectivamente, sobre a densidade óssea vertebral). O mesmo é encontrado em meta-análise realizada por MARTYN e CARROL (2010), na qual concluem que exercícios de impacto associados aos de resistência apresentam efeito positivo. Por outro lado, atividades aquáticas, como natação e hidroginástica, não exerçam benefícios consistentes para a saúde óssea (EMSLANDER e cols., 1998).

$\mathrm{O}$ efeito do exercício em indivíduos não atletas parece não ocorrer a curto prazo, no entanto, acredita-se ser substancial se acumulado ao longo dos anos (WALLACE e CUMMING, 2000)

Em suas posições oficiais, o American College Sports of Medicine (ACSM) sugere que, em adultos, o incremento da densidade óssea ocorra somente com exercícios aeróbios de alta intensidade e resistidos. A freqüência varia conforme a modalidade. Para exercícios de impacto, recomenda-se de 3 a 5 vezes por semana e para os de resistência, de 2 a 3 vezes por semana, com duração de trinta a sessenta minutos cada (ACSM, 2004). 


\subsection{FATORES NUTRICIONAIS}

Embora existam diversas evidências sobre a associação entre micro e macronutrientes e baixa massa óssea, poucos são os estudos que relacionam o consumo dietético e elevada densidade óssea.

A seguir serão descritos alguns nutrientes, bem como padrões alimentares relacionados à DMO.

\subsubsection{Proteina}

Constituinte primário do osso, a proteina, apresenta efeito anabólico benéfico ao osso, especialmente se o consumo de cálcio for adequado (DAWSON-HUGHES e HARRIS, 2002).

A proteína dietética regula a produção hepática e os níveis plasmáticos do hormônio de crescimento $(\mathrm{GH})$ e do IGF-1, responsável por exercer funções como diferenciação, maturação e recrutamento dos osteoblastos (BORBA, 2003). Sua restrição contribui para a diminuição plasmática deste hormônio, podendo influenciar no metabolismo ósseo, visto que o aumento do remodelamento ósseo e redução da formação óssea estão relacionados com baixos níveis plasmáticos de IGF-I (AMMANN e cols., 2000), dependente da ingestão protéica (HEANEY e cols., 1999).

Embora as dietas hipoprotéicas reduzam a densidade mineral óssea devido ao comprometimento no recrutamento e na atividade dos osteoblastos decorrentes da diminuição de IGF-1 (BOURRIN e cols., 2000), as dietas hiperproteicas apresentam resultados controversos. HUNT e cols. (2009) revelam um incremento de $27 \%$ dos valores de IGF-1 em dieta com um aumento de proteínas indicando efeito benéfico ao metabolismo ósseo. Por outro lado, estudo com dieta hiperprotéica demonstra aumento da excreção renal de cálcio, ocasionando efeito negativo na DMO (HEANEY, 1993). Este efeito parece ser minimizado quando há ingestão adequada de cálcio e de vitamina D (SCHÜRCH e cols., 1998). 


\subsubsection{Lipídeos}

Alguns estudos encontraram associação negativa entre consumo de lipídeos e DMO (MICHAELSSON e cols., 1995; COOPER e cols., 2000; MACDONALD e cols., 2004).

Estudo em modelo animal realizado por HALADE e cols. (2010) evidencia a associação entre consumo de gorduras, obesidade e redução de massa óssea.

Sabe-se que o maior consumo de lipídeos pode comprometer a absorção do cálcio, a síntese do prostaglandinas e a osteoblastogênese (WATKINS e cols., 2003; PARHAMI e cols.,2003).

É responsável pelo aumento da oxidação do lipídeos (WATKINS e cols., 2003; PARHAMI e cols.,2003, CORWIN e cols., 2003). Além disso, está relacionada com maior expressão dos fatores de diferenciação da adipogênese, em especial os PPAR- $\gamma$ (receptores ativados por proliferadores de peroxissoma gama) (INOUE e cols., 2005; YU e cols. 2003; ACKERT-BICKNELL e cols, 2008).

De acordo com os dados do Framingham Osteoporosis Study, o elevado consumo de gordura pode ser prejudicial para a massa óssea, particularmente em indivíduos com maior variação alélica do PPAR- $\gamma$ (ACKERT-BICKNELL e cols, 2008).

\subsubsection{Cálcio e Vitamina D}

O cálcio é o mineral mais abundante no organismo, sendo que aproximadamente $99 \%$ encontram-se no esqueleto e o restante distribui-se nos dentes, fluídos corporais e tecidos moles (NORDIN, 1997). Está envolvido em funções biológicas como a contração muscular, mitose, coagulação sanguínea, transmissão do impulso nervoso ou sináptico e suporte estrutural do esqueleto (MILLER e cols., 2001).

O papel do cálcio no metabolismo ósseo é amplamente conhecido (MATKOVIC e cols., 2004), assim como o fato de que sua deficiência acarreta alterações na densidade mineral óssea (BROADUS, 2003). 
Este mineral é necessário para maximizar o pico de massa óssea, manter a massa óssea na idade adulta e minimizar a perda decorrente da idade (MATKOVIC e cols., 2004).

A recomendação de cálcio varia conforme os estágios de vida e foram revistas e publicadass em 2010 pelo comitê do Food and Nutrition Board/ Institute of Medicine (IOM) dos Estados Unidos, sendo de $1000 \mathrm{mg} /$ dia para ambos os sexos entre 19 a 50 anos. Este valor é recomendado para o sexo masculino até os 70 anos. Há uma diferenciação de valores para o sexo feminino a partir dos 50 anos ( $1200 \mathrm{mg} /$ dia); portanto, a partir dos 70 anos, para ambos os sexos, a recomendação é de 1200mg de cálcio/dia (IOM 2011).

No Brasil essa ingestão pode ser bastante diversificada devido aos diferentes hábitos regionais. Apesar disto dados obtidos em uma amostra representativa do Estado de São Paulo evidenciam o baixo consumo de cálcio, segundo gênero e idade (483 mg/d para mulheres e $410 \mathrm{mg} / \mathrm{d}$ para homens) (BUENO e cols., 2008). O Brazilian Osteoporosis Study (BRAZOS) ao avaliar 2420 indivíduos brasileiros em 15 estados, corrobora com os dados descritos anteriormente. O consumo médio nacional diário de cálcio foi de 400mg/dia (PINHEIRO e cols., 2009).

Segundo PEREIRA e cols. (2009) os principais motivos para a baixa ingestão de cálcio pelos brasileiros se deve, provavelmente, ao elevado custo dos principais alimentos-fonte, hábitos culturais e alimentares.

Além do consumo, outro ponto que se deve considerar é a biodisponibilidade do cálcio que depende de fatores exógenos, como fitatos, oxalatos, taninos e sódio que agem de maneira negativa; dos oligossacarídeos cuja fermentação produz ácidos graxos de cadeia curta que acidificam o intestino estimulando a absorção de cálcio e de fatores endógenos como idade, condições físiológicas e regulação hormonal (PEREIRA e cols., 2009).

Um dos fatores hormonais é a vitamina $\mathrm{D}$, nutriente que funciona como próhormônio, apresentando a mesma estrutura molecular que os hormônios esteróides (NORMAN, 2008).

É adquirida de duas formas: via alimentação e pela exposição solar, sendo que a última é responsável por $80 \%$ a $90 \%$ dos estoques (HOLICK, 1999). A ampla 
distribuição do seu receptor VDR pelo organismo amplia os efeitos benéficos em diversos tipos de células e tecidos (HOLICK, 2004. NORMAN, 2008).

Recentemente novas recomendações de vitamina D foram publicadas pelo mesmo comitê descrito anteriormente. A recomendação aumentou em 400UV/dia ou $10 \mu \mathrm{g} /$ dia, sendo: $15 \mu \mathrm{g} /$ dia para indivíduos entre 31 e 70 anos e $20 \mu \mathrm{g} /$ dia para indivíduos acima de 70 anos; baseada em publicações cientificas consistentes, visando não só o metabolismo ósseo, mas também os efeitos extra-ósseos. (1OM, 2011). Porém, em relatório publicado pelo IOM revela que estes últimos efeitos são inconclusivos e não podem ser confiáveis, sendo necessários mais estudos para a comprovação deste efeito.

Alguns autores acreditam que estas novas recomendações permanecem aquém da necessidade real de Vitamina D para a manutenção da massa óssea e beneficios extra-osseos (HEANEY e HOLICK, 2011).

Em nosso meio, FISBERG (2005) encontrou valores de consumo de vitamina $\mathrm{D}$ inferior ao recomendado. A média de ingestão em mulheres acima de 51 anos foi de mulheres 3,21 $\mu \mathrm{g} / \mathrm{dia}$. Em mulheres idosas com osteoporose o valor médio de consumo foi de 4,2 $\mu \mathrm{g}$ /dia (GENARO e cols., 2006). Baixo consumo também foi encontrado pelo $B R A Z O S$ ao avaliar uma amostra representativa da população brasileira, a ingestão média foi de 1,86 $\mu \mathrm{g} /$ dia (PINHEIRO e cols., 2009).

Maiores detalhes sobre metabolismo da vitamina D serão descritos posteriormente no subitem "perfil hormonal".

\subsubsection{Fósforo}

Mineral essencial para a formação óssea, a ação do fósforo no metabolismo ósseo está relacionada com os níveis de cálcio e paratormônio (PRENTICE, 2004).

Estudo em modelo animal sugere que dietas ricas em fósforo aumenta a expressão do RNAm do RANKL ocasionando diferenciação e aumento do número de osteoclastos (KATSUMATA e cols., 2005).

Em humanos, dietas ricas em fósforo associadas ao baixo consumo de cálcio gera alterações no metabolismo do cálcio com aumento da secreção de PTH favorecendo a perda óssea (CALVO, 1990). PINHEIRO e cols. (2009) confirmam isto ao demonstrarem que a cada $100 \mathrm{~g}$ de fósforo consumido o risco de fratura 
aumenta em 9\%. Deve-se considerar que este efeito parece ocorrer apenas em dietas com baixo conteúdo de cálcio (BIZIK, 1996).

No entanto, é importante salientar que dietas restritas em fósforo não promovem ganho de DMO, mas podem ocasionar balanço negativo de fósforo e, assim, maior perda óssea. Desse modo, o adequado consumo de fósforo e cálcio é essencial para a mineralização óssea.

\subsubsection{Padrão alimentar}

A avaliação de nutrientes ou alimentos de maneira individual pode não ser a maneira mais adequada, uma vez que os indivíduos consomem dietas consistindo de uma variedade de alimentos com complexas combinações de nutrientes, ao inves de nutrientes isolados (OKUBO e cols., 2006). Diante disto os padrões alimentares, método que explora os múltiplos componentes dietéticos, estão sendo utilizados em inúmeros estudos.

Os padrões alimentares têm sido descritos associados com algumas doenças crônicas, incluindo doenças cardiovasculares e diabetes (KANT, 2004), mas poucos estudos têm investigado o impacto da padrões alimentares específicos na saúde óssea.

Um estudo de coorte, no Canadá, demonstrou que um padrão alimentar, incluindo frutas, legumes e grãos foi associado a um risco reduzido de fratura em homens e mulheres (LANGSELMO e cols, 2011). Do mesmo modo, TUCKER e cols. (2002) investigaram padrões alimentares entre homens e mulheres com idades 60-93 anos e descobriram que um padrão de dieta rica em frutas, legumes e cereais está associado à maior DMO, enquanto que um padrão alimentar rico em produtos de confeitaria associou-se a menor DMO. MC NAUGHTON e cols. (2011) ao avaliarem 527 mulheres australianas entre 18 a 65 anos identificaram uma associação benéfica à DMO do padrão alimentar que consistia de legumes, sementes, mariscos, frutos secos, vinho, arroz e vegetais.

OKUBO e cols. (2006) ao avaliarem 291 japonesas rurais na pré menopausa demosntraram que o padrão saudável com alto consumo de peixe, frutas, vegetais e baixo consumo de carnes processadas tem efeito benéfico na DMO. Entre as 
mulheres gregas, KONTOGIANNI e cols., (2009) descobriram que um padrão alimentar caracterizado por peixe, óleo de oliva, e de baixo consumo de carne vermelha foi associada com maior DMO. Já, mulheres escocesas com idade entre 50 e 59 anos com um padrão alimentar saudável, rico em frutas e vegetais pode levar à menor reabsorção óssea, enquanto que um padrão alimentar rico em alimentos processados está associado a menor DMO (HARDCASTLE e cols. 2011).

Como observado nos diferentes estudos, o padrão alimentar varia segundo a população estudada, mesmo considerando esta variação parece que um padrão alimentar saudável apresenta impacto positivo na DMO.

\subsection{DOENÇAS}

Alguns estudos revelam associação entre o câncer de mama, endométrio e EDMO (CAULEY e cols., 1996; DOUCHI e cols., 1999; VAN DER KLIFT e cols., 2003; GANRY e cols., 2004; CHEN e cols., 2008).

GANRY e cols. (2004) ao avaliarem 1504 mulheres acima de 75 anos e dividi-las em tercis segundo DMO, evidenciaram que mulheres com DMO superior (DMO do trocanter $>0,704 \mathrm{~g} / \mathrm{cm}^{2}$ e DMO do colo do fêmur $>0,769 \mathrm{~g} / \mathrm{cm}^{2}$ ) apresentam 2,2 a 2,3 vezes maior risco de câncer de mama quando comparadas à mulheres com DMO inferior. GREINER e cols. (2011) encontraram resultados semelhantes em estudo de coorte, envolvendo 37860 mulheres acima de 50 anos, com divisão em quartis segundo DMO, as mulheres no quartil superior, segundo DMO de coluna lombar, apresentaram 1,32 vezes maior risco de câncer de mama. Os principais mecanismos envolvidos são a associação com maiores concentrações séricas (ETTINGER e cols., 1998) e o polimorfismo do estrogênio (HARVEY, 2005).

Além da condição hiperestrogênica, ressaltam-se a relação com a obesidade tanto pela força mecânica, exercida pelo peso em si, como pela liberação de hormônios provenientes do tecido adiposo (BORBA, 2003; REID e cols., 2006; REID, 2008).

Outro fator implicado parece ser o aumento da conversão do estrógeno no tecido adiposo, gerando consequentemente, uma exposição cumulativa de estrógeno 
que contribuiria para EDMO em mulheres obesas e com câncer (DOUCHI e cols., 1999). Adicionalmente, baixas concentrações de globulina ligadora dos hormônios sexuais (SHBG) estão associadas à alta massa gorda (KIRSCHNER e cols., 1990) e a redução destas concentrações pode levar a um aumento dos esteróides sexuais circulantes, podendo contribuir para a EDMO (DOUCHI e cols., 1999; RICCI, 2001).

A hiperinsulinemia também pode ser responsável pelo efeito positivo na DMO, tanto na obesidade, presente ou não em mulheres com câncer, quanto no diabetes. YAMAGUCHI e cols. (2009) demonstram que a hiperinsulinemia pode aumentar a DMO do fêmur em diabéticos do tipo 2. MA e cols. (2012) corroboram para estes resultados, uma vez que indivíduos com diabetes tipo 2 apresentaram $25 \%$ a 50\% maior DMO quando comparados aos indivíduos controles, não diabéticos. O provável mecanismo se dá em virtude do declínio na produção da proteína 1 de ligação ao fator de crescimento semelhante à insulina (IGFBP-1) e com isso aumentaria a ação do fator de crescimento semelhante a insulina (IGF-1), o qual estimularia a proliferação dos osteoblastos (ALBALA e cols., 1996).

\subsection{MEDICAMENTOS}

Os medicamentos associados ao aumento da DMO são os diuréticos tiazídicos e as estatinas.

Os diuréticos tiazídicos reduzem a pressão arterial e previnem complicações cardiovasculares decorrentes da hipertensão, além disso, são utilizados no tratamento da nefrolitíase por reduzirem a excreção de cálcio urinário (LaCROIX e cols., 1990).

OLMOS e cols. (2010) ao avaliarem 636 mulheres hipertensas e 343 mulheres saudáveis na pós-menopausa encontraram maior DMO e menor remodelamento ósseo naquelas que faziam uso de tiazídico quando comparadas ao grupo controle. Estudos clínico randomizados mostram um modesto aumento da DMO (LaCROIX e cols., 2000; REID e cols., 2000; BOLLAND, 2007), porém este efeito parece ser dose dependente, sendo mais evidente entre os seis e os doze meses iniciais ao tratamento. 
Os mecanismos pelo qual isto ocorre não estão totalmente elucidados. Os tiazídicos reduzem a excreção urinária de cálcio podendo levar a um aumento das concentrações de cálcio sérico, ocasionando redução das concentrações de PTH e diminuição do romodelamento ósseo, porém OTT e cols. (2008) e BOLLAND e cols. (2007) não encontraram alterações nas concentrações séricas de cálcio e PTH.

Outro fator relevante é o aumento do bicarbonato ocasionado pelo tiazídico que altera a excreção urinária de cálcio e a alcalose suave é benéfica aos ossos (LEMANN e cols., 2003).

Adicionalmente, DVORAK e cols. (2007) demonstraram que os tiazídicos podem atuar de forma direta estimulando a formação dos osteoblastos, independente de seus efeitos nos rins, e parece inibir os osteoclastos (HALL e SCHAUEBLIN, 1994) favorecendo a redução da remodelação óssea.

As estatinas são medicamentos utilizados para reduzir as concentrações de colesterol sanguíneo (BUCHER e cols., 1999).

Os resultados dos estudos em relação a sua ação na DMO são conflitantes (RIZZO e cols., 2004).

Estudos observacionais em ratos não levam a resultados conclusivos. Aparentemente a DMO não é alterada (MARITZ e cols., 2001) ou quando ocorre alteração é um modesto aumento na administração crônica (KAWANE e cols., 2004).

Já, em humanos, TANRIVERDI e cols. (2005) ao avaliarem mulheres na pósmenopausa com osteopenia e/ou osteoporose revelaram que o efeito da estatina associada ao uso de bisfosfonato apresenta efeito potencializado quando comparado ao uso do bisfosfonato isolado. As mulheres com o uso de ambas as medicações apresentaram aumento significante na DMO da coluna lombar quando comparadas às mulheres que faziam uso apenas do bisfosfonato. Resultados positivos também foram encontrados por CHUENGSAMARN e cols. (2010) em estudo prospectivo, randomizado, controlado, ao avaliarem 212 pacientes dislipidêmicos com osteopenia, encontraram valores maiores do marcador de formação óssea (P1NP) e valores menores do marcador de reabsorção óssea (CTX) no grupo que recebeu estatina. 
Em relação aos marcadores bioquímicos outros estudos demonstram que parece haver um pequeno aumento da osteocalcina (CHAN e cols., 2001) e redução da fosfatase alcalina, podendo ser dose dependente (STEIN e cols., 2001).

Apesar disto, em estudo de revisão de RIZZO e RINI (2006) mostraram que alguns estudos observacionais e prospectivos apresentam resultados conflitantes.

Vale salientar que as estatinas agem na mesma via metabólica dos bifosfonatos, alendronato e residronato, os quais sabidamente reduzem a perda de massa óssea em mulheres com osteoporose pela apoptose dos osteoclatos (GARRET e cols., 2001). Este fato pode contribuir para justificar os efeitos positivos encontrados em alguns estudos.

\subsection{PERFIL HORMONAL}

Alterações no perfil hormonal refletem na DMO (DELUCA, 2004; HOLICK, 2004b, PERRIEN, 2006; REID, 2008; ARABI e cols. 2012). Os hormônios relacionados à obesidade como a leptina e os hormônios pancreáticos, já foram discutidos anteriormente em antropometria e composição corporal. A seguir serão descritos outros hormônios que interferem na DMO.

\subsubsection{Vitamina D e Paratormônio}

Em relação ao metabolismo ósseo, sua forma ativa (calcitriol) atua em conjunto com o paratormônio na reabsorção renal de cálcio e na reabsorção óssea. Também aumenta a eficácia da absorção intestinal de cálcio dietético a fim de manter os níveis de cálcio sanguíneos fisiologicamente estáveis (DELUCA, 2004; HOLICK , 2004b).

O consumo de vitamina $\mathrm{D}$ e a exposição solar adequada são necessários para a manutenção da $25(\mathrm{OH}) \mathrm{D}_{3}$. Em relação ao consumo, poucos são os alimentos que contêm vitamina $\mathrm{D}$ e no Brasil, diferente do que ocorre em outros países, não há a fortificação alimentar. Fatores ambientais (latitude, estações do ano, a camada de 
ozônio e a nebulosidade) e pessoais (tipo de pele, idade, vestimentas e uso de protetor solar) estão envolvidos com o nível de suficiência ou insuficiência da vitamina D e a saúde óssea (WEBB e cols., 2006; BANDEIRA e cols., 2010; MALLAH e cols., 2011).

Sua deficiência causa osteomalácia e que pode estar acompanhada de baixa massa óssea (DELUCA, 2004; HOLICK, 2004b; HOLICK e cols., 2011).

Estudo realizado por KUCHUK e cols. (2009) em 29 países dos seis continentes em mulheres na pós-menopausa revelam alta prevalência de baixas concentrações séricas da $25(\mathrm{OH}) \mathrm{D}$. Esta deficiência de vitamina D está presente independe da faixa etária e da classe sócio-econômica (SARAIVA e col, 2007; VIETH e col, 2007).

No Brasil, estudo realizado por SARAIVA e cols. (2007) em idosos, revela que $71,2 \%$ dos idosos institucionalizados e $43,8 \%$ dos idosos não institucionalizados apresentavam concentrações de vitamina D abaixo do mínimo recomendado, segundo os pontos de corte de $20 \mathrm{ng} / \mathrm{mL}$. Corroborando com estes resultados GENARO e cols. (2006) encontraram $80 \%$ de deficiência de Vitamina D em mulheres na pós menopausa.

A maioria das pesquisas concorda que o melhor indicador para avaliar a adequação de vitamina $\mathrm{D}$ é utilizar a $25(\mathrm{OH}) \mathrm{D}$ pois além de refletir os estoques obtidos pela absorção da dieta e síntese cutânea, apresenta uma variedade de ensaios clínicos que podem ser utilizados, e adicionalmente se correlaciona com muitas doenças (TRANG e cols., 1998; SAENGER e cols., 2006; HOLICK e cols., 2011).

Estudo realizado em mulheres na pós-menopausa em seis continentes revela que o aumento da $25(\mathrm{OH}) \mathrm{D}$ por categoria $(<25,25-50,50-75$, e $>75 \mathrm{nM})$ apresentou declínio significativo de PTH, osteocalcina e CTX, enquanto que a DMO dos sítios avaliados apresentaram um aumento significativo (KUCHUK e cols., 2009), porém não mencionaram EDMO.

Apesar do consenso acerca de qual forma de vitamina D deve-se avaliar, não há um consenso internacional sobre os valores de corte para se definir o estado da vitamina D. Apesar disso, vários autores concordam no valor de $75 \mathrm{nmol} / \mathrm{L}$ de 25(OH)D,(VIETH, 2004; BOULLON, 2005; GRANT e HOLICK, 2005) com base 
no limiar necessário para a supressão máxima do PTH, melhor absorção de cálcio e maior DMO e prevenção de fraturas (DAWSON-HUGHES e cols., 2005).

Em relação ao PTH embora a elevação persistente deste ocasione perda óssea acelerada, a administração intermitente de PTH 1-34 (teriparatida) aumenta a densidade e a qualidade óssea, reduz a taxa de fraturas vertebrais por osteoporose (DATTA, 2011; HAN e cols., 2012; WALSH e cols., 2012), sendo utilizado na prática clínica.

\subsubsection{Hormônios sexuais}

O hormônio liberador de gonadotrofina $(\mathrm{GnRH})$ é secretado pelo hipotálamo e estimula a secreção do hormônio folículo estimulante (FSH) e do hormônio luteinizante (LH) na adeno-hipófise. Nas mulheres, estes hormônios atuam nos ovários estimulando-os a secretar estrógeno, progesterona e inibina (PRIOR, 2006; SENDAK e cols., 2007). Depois disto, o estrógeno e a inibina, que, por sua vez, regulam a secreção do $\mathrm{GnRH}, \mathrm{FSH}$ e $\mathrm{LH}$, por mecanismo de retroalimentação (XU e cols., 2009).

A perda desse mecanismo, como na menopausa (hipoestrogenismo), por exemplo, aumenta as concentrações plasmáticas do FSH e LH, que desempenham papel negativo sobre o tecido ósseo (MANSELL e cols., 2007).

Ao contrário do estrógeno e da inibina, que em altas concentrações conferem proteção à massa óssea (PERRIEN e cols., 2006), os hormônios FSH e LH em concentrações elevadas, parecem contribuir para o aumento da reabsorção óssea, porém os resultados são conflitantes.

Alguns estudos demonstram que o aumento sérico de $\mathrm{FSH}$ e redução de inibina ocasiona perda óssea em mulheres na perimenopausa (VURAL e cols., 2005; PERRIEN e cols., 2006). Em contrapartida, a redução nas concentrações plasmáticas do FSH parece estar correlacionada com ganho de massa óssea (SOWERS e cols., 2003),

XU e cols. (2009) ao avaliarem 699 mulheres chinesas saudáveis com idade entre 20 e 82 anos, sendo 464 na pré-menopausa e 235 na pós-menopausa demonstraram que os hormônios FSH e LH apresentaram-se aumentados nas mulheres com 40 anos e reduzidos nas mulheres com 60 anos. Em relação à massa 
óssea, após divisão em quartis, evidenciaram que a cada aumento de $10 \mathrm{UI} / \mathrm{L}$ de FSH e LH resultaram em diminuição de $5,5 \%$ e $4,4 \%$ da DMO de coluna, respectivamente. Os outros sítios esqueléticos avaliados também apresentaram reduções que variaram entre $2,4 \%$ a $4,8 \%$.

Especula-se que o FSH regule diretamente a massa óssea pela estimulação de células de reabsorção óssea (osteoclastos). Estudos in vitro evidenciam receptores de FSH na superficie dos osteoclastos (BOYLE e cols., 2003).

Adicionalmente, o FSH estimularia as células imunes a produzir o fator de necrose tumoral alfa (TNF- $\alpha$ ) e este, por sua vez, estimularia as células precursoras dos osteoclastos e a diferenciação dos mesmos (IQBAL, 2006; SUN e cols., 2006).

Contrariando os achados descritos anteriormente DRAKE e cols. (2010) realizaram uma intervenção direta na supressão da secreção de FSH, utilizando um antagonista do mesmo, em estudo randomizado, duplo-cego, placebo controlado, envolvendo 46 mulheres na pós-menopausa e não identificaram o FSH como regulador da reabsorção óssea. Indo ao encontro deste achado RITTER e cols. (2008) administraram FSH em ratos machos durante um mês e não verificaram efeito sobre a DMO no fêmur, avaliado por tomografia.

Diante disto o papel do FSH ainda encontra-se incerto, devendo ser investigado. Em relação ao LH e sua influência sobre o tecido ósseo, ainda, não é conhecido, mas especula-se que possa induzir o aumento dos androgênios (BARON, 2006)

\subsection{PERFIL LIPÍDICO}

Alguns estudos clínicos sugerem a possibilidade de uma relação entre a hipercolesterolemia e massa óssea (KOSHIYAMA e cols., 2001; YAMAGUSHI e cols., 2002; WU e cols., 2003; TANCO e col, 2003; ADAMI e cols., 2004; OROSCO, 2004; CUI e cols., 2005) . Os resultados são controversos, alguns estudos encontraram uma diminuição da DMO (KOSHIYAMA e cols., 2001; YAMAGUSHI e cols., 2002; WU e cols., 2003; TANCO e col, 2003; OROSCO, 2004; CUI e cols., 2005; MAKOVEY e cols., 2009), outros um aumento da DMO (ADAMI e cols., 2004; HERNANDEZ e cols., 2010) e outros ainda não encontraram nenhuma associação (SAMELSON e col, 2004; PLIATSIKA e cols., 2012). Por outro lado, 
estudos em modelo animal in vivo $\mathrm{e}$ in vitro encontraram associação entre dislipidemia e massa óssea (PARHAMI e cols., 1999; TINTUT e cols., 2002; TINTUT e cols., 2004).

Os estudos in vitro revelaram que produtos da oxidação de lipídeos e lipoproteínas inibem a diferenciação e função osteoblastos (PARHAMI e cols., 1999; TINTUT e cols., 2002).

HERNANDEZ e cols. (2010), em estudo transversal, encontraram baixo turnover ósseo, avaliados por Propeptídeo do colágeno tipol (P1NP) e Betacarboxitelopeptídeo (beta-CTX) séricos, em indivíduos hipercolesterolêmicos comparados ao controle. Em contrapartida, estudo caso-controle, realizado por MAJIMA e cols. (2008), ao avaliarem N-telopeptídeo do colágeno (NTx) de pacientes com hipercolesterolemia e compará-lo com controles revelaram aumento no turnover ósseo de indivíduos hipercolesterolêmicos, o que sugere a importância da melhora da hipercolesterolemia para não só prevenir a aterogenese, como também a osteoporose.

Os estudos não conseguiram definir, de forma efetiva, a via pela qual isto ocorra, porém parece estar associado à via do mevalonato por estar envolvida na síntese do colesterol, na proliferação de células ósseas e na apoptose de osteoclastos (CUMMINGS e BAUER, 2000; BUHAESCU e cols., 2007).

Diante do exposto torna-se evidente as contradições e dúvidas acerca dos inúmeros fatores que possivelmente determinam a EDMO. No Brasil estudos com estes indivíduos são desconhecidos, reforçando ainda mais a necessidade de aprofundar este assunto. 


\section{OBJETIVOS}

\subsection{OBJETIVO GERAL}

Identificar os fatores associados à elevada densidade mineral óssea em mulheres adultas.

\subsection{OBJETIVOS ESPECÍFICOS}

- Artigo 1 - Revisar e discutir os aspectos relacionados à EDMO.

- Artigo 2 - Identificar a prevalência, bem como os fatores de risco e proteção associados com a EDMO em mulheres saudáveis.

- Artigo 3 - Caracterizar o padrão alimentar e pontuar as diferenças existentes no mesmo, de acordo com a DMO. 


\section{METODOLOGIA}

\subsection{DELINEAMENTO}

Trata-se de um estudo tranversal.

\subsection{POPULAÇÃO DO ESTUDO}

Foram selecionadas, de forma consecutiva, mulheres que realizaram densitometria óssea (aparelho Lunar-GE) e cujo resultado evidenciou elevada densidade óssea da coluna lombar [maior do que 1,400 g/ $\mathrm{cm}^{2}$ (T-score maior ou igual a 2,0 desvios-padrão)] e/ ou fêmur proximal [maior do que $1,200 \mathrm{~g} / \mathrm{cm}^{2}$ (Tscore maior ou igual a 2,0 desvios-padrão)], desde que nenhum desses sítios apresentasse osteopenia ou osteoporose. O T-score acima de 2 desvios-padrão foi escolhido após revisão da literatura, que configura esse valor ao diagnóstico de valores acima da normalidade.

O grupo controle foi constituído por mulheres saudáveis, pareadas para a idade e peso, com massa óssea normal (T-score entre +1 e -1 desvio-padrão na coluna lombar e no fêmur proximal). O T-score entre 1 desvio-padrão foi escolhido baseado na distribuição da massa óssea, de acordo com a curva de Gauss, ou seja, que utiliza 1 desvio-padrão para identificar $67 \%$ da população como normal.

Os dois grupos foram selecionados do banco de dados da Fundação Instituto de Diagnóstico por Imagem (FIDI).

De um total de aproximadamente 21.000 densitometrias realizadas na área metropolitana da cidade de São Paulo, foram encontradas 421 com EDMO, destas 381 foram excluídas por não se adequarem ao critério de inclusão $(98 \%)$ ou não ter interesse em participar do estudo (2\%), restando 40 mulheres saudáveis com EDMO, sendo pareadas ao grupo controle em relação à idade e peso. 


\subsubsection{Cálculo do tamanho amostral}

Para o cálculo do tamanho amostral foi utilizada a estimativa de prevalência de elevada DMO em uma amostra de 18.000 densitometrias realizadas. A partir desta estimativa os valores de prevalência foram de $1,31 \%$.

Considerando a prevalência de elevada DMO de 1,31\%, o cálculo do tamanho amostral foi realizado segundo LEVINE (2000) e é dado por:

$$
\mathrm{n}=\frac{\left(\mathrm{Z} \alpha_{2}\right)^{2} \cdot \mathrm{p} \cdot \mathrm{q}}{\mathrm{E}^{2}}
$$

Em que:

$\mathrm{n}=$ Número de indivíduos da amostra

$\mathrm{Z} \alpha /_{2}=$ Valor crítico que corresponde ao grau de confiança desejado $95 \%$

$\mathrm{p}=$ Proporção populacional de indivíduos que pertencem à categoria que estudamos

$\mathrm{q}=$ Proporção populacional de indivíduos que não pertencem à categoria que estudamos $(\mathrm{q}=1-\mathrm{p})$

$\mathrm{E}=$ Margem de erro ou erro máximo de estimativa. Identifica a diferença máxima entre a proporção amostral e a verdadeira proporção populacional $(0,05)$.

O valor obtido foi de 14 mulheres.

\subsubsection{Critérios de inclusão}

Os indivíduos foram selecionados de acordo com os seguintes critérios:

- Sexo feminino.

- Índice de massa corpórea (IMC) menor ou igual a $29,9 \mathrm{~kg} / \mathrm{m}^{2}$.

- Idade entre 30 e 65 anos, ou seja, após o pico de massa óssea e antes da senescência, a fim de afastar problemas degenerativos da coluna lombar, que pudessem superestimar a real densidade óssea vertebral.

- Etnia branca, caucasóide, parda ou oriental.

\subsubsection{Critérios de exclusão}

- Sexo masculino.

- IMC maior do que $29,9 \mathrm{~kg} / \mathrm{m}^{2}$ e menor do que $18,5 \mathrm{~kg} / \mathrm{m}^{2}{ }^{2}$ baseado na classificação da OMS (2000). 
- Etnia negra

- Indivíduos com histórico de etilismo.

- Indivíduos dislipidêmicos.

- Indivíduos portadores de hepatite C.

- Presença de alterações degenerativas em coluna lombar evidenciadas com radiografia simples da coluna lombar.

- Indivíduos com alguma deficiência cognitiva que os impossibilitem de fornecer respostas adequadas, tais como seqüelas neurológicas ou demências senis.

- Uso de medicações que interferem no metabolismo ósseo, inclusive tiazídicos e estatinas.

- Doenças associadas com desequilíbrio nutricional e metabolismo óssea, como doença renal, infecciosas, digestivas, neoplásicas, endócrinas, doenças reumáticas e doenças cardiovasculares, sendo obtidas por auto-relato.

Os indivíduos foram informados sobre o estudo e, concordando em participar, assinaram um termo de consentimento (Anexo I) para responderem aos questionários e realizarem os exames bioquímicos e radiológicos previstos. Caso o tempo de realização do DXA fosse superior a seis meses o indivíduo era informado que o exame seria realizado novamente.

\subsection{PROTOCOLO DE ESTUDO}

As mulheres foram avaliadas após explicação do projeto e assinatura do termo de consentimento (Anexo I), conforme preconiza a resolução $\mathrm{n}^{\circ} 916$ do Conselho Nacional de Saúde, de 10 de Outubro de 1996.

$\mathrm{O}$ estudo constou de avaliações antropométrica, radiológica, de densidade mineral óssea, composição corporal e do perfil bioquímico. Além disso, foram aplicados três questionários validados a fim de avaliar fatores de risco da massa óssea (Anexo II), fatores nutricionais (Anexo III) e escore de atividade fisica (Anexo IV), com a finalidade de identificar todos os possíveis fatores associados à EDMO. 


\subsubsection{Etnia}

Diante da grande miscigenação que ocorre no Brasil optou-se por classificar em brancos e não brancos. Vale salientar que as mulheres negras foram excluídas do estudo.

\subsubsection{Avaliação antropométrica}

A avaliação antropométrica foi realizada por meio da aferição do peso e estatura de acordo com as técnicas propostas por FRISANCHO (1993):

$\underline{\text { Peso: }}$ : medido em quilograma $(\mathrm{kg})$. As pacientes utilizaram roupas leves e estavam descalças, sendo posicionadas sobre a balança do tipo plataforma , marca Filizola ${ }^{\circledR}$, com capacidade para $150 \mathrm{~kg}$ e precisão de $100 \mathrm{~g}$.

Estatura: foi utilizado o estadiômetro da própria balança. As pacientes foram orientadas a permanecer de costas para o estadiômetro, em posição ereta e com os pés unidos. O plano horizontal de Frankfurt foi utilizado nesta aferição (parte inferior do globo ocular em linha horizontal com o conduto auditivo externo). A leitura foi realizada no centímetro mais próximo, com variação de $0,5 \mathrm{~cm}$, quando a haste do estadiômetro recostava sobre a cabeça.

Com estes dados foi calculado o IMC (Índice de Massa Corporal), definido como massa corporal em quilos dividido pela estatura em metros quadrados $\left(\mathrm{kg} / \mathrm{m}^{2}\right)$, sendo classificados de acordo com os critérios propostos pela Organização Mundial da Saúde (OMS, 2000). 
Quadro 1: Classificação do Índice de Massa Corporal (IMC)

\begin{tabular}{|c|c|}
\hline $\boldsymbol{I M C}\left(\mathbf{K g} / \mathbf{m}^{\mathbf{2}}\right)$ & Classificação \\
\hline$<16$ & Magreza grau III \\
\hline $16,0-16,9$ & Magreza grau II \\
\hline $17,0-18,4$ & Magreza grau I \\
\hline $18,5-24,9$ & Eutrófico \\
\hline $25-29,9$ & Pré-obeso \\
\hline $30-34,9$ & Obesidade grau I \\
\hline $35-39,9$ & Obeisidade grau II \\
\hline$\geq 40$ & Obesidade grau III \\
\hline
\end{tabular}

Fonte: OMS, 2000

\subsubsection{Avaliação radiológica:}

A avaliação radiológica da coluna lombar (L1 a L4), nas posições pósteroanterior e perfil, foi realizada por um reumatologista para excluir processo degenerativo vertebral ou outras causas de elevada massa óssea, tais como metástases ósseas, doença de Paget, fratura ou deformidades congênitas (hérnia de Schmorl, escoliose grave). Os seguintes critérios foram utilizados no protocolo de aquisição das imagens pela radiologia convencional da coluna vertebral: distância do tubo-filme foi de $120 \mathrm{~cm}$, com feixe de raios X centrado em L3.

\subsubsection{Avaliação da Densidade Mineral Óssea :}

$\mathrm{O}$ estudo da densidade mineral óssea foi realizado na coluna lombar e fêmur proximal, utilizando-se o densitômetro de dupla emissão com fonte de raios X ( $G E$ Lunar Radiation Corporation, modelo DPX, Madison, WI, USA). Esse exame foi realizado previamente, uma vez que constitui critério de inclusão.

$\mathrm{O}$ procedimento técnico padrão foi adotado para o posicionamento dos pacientes para a realização do exame com controle de qualidade diário. Assumimos os dados de referência do fabricante (NHANES), que são semelhantes à curva normal brasileira. O modo médio (medium scan mode) e a análise é feita com o 
programa Lunar versão $3,6 \mathrm{z}$. Tanto a aquisição do exame quanto a análise da densidade mineral óssea foram realizadas pelo mesmo examinador na mesma visita. O coeficiente de variação do método em nosso serviço é de 3,6\% para o fêmur e de $2 \%$ para a coluna. Controle de qualidade do aparelho foi realizado diariamente, conforme instruções do fabricante.

As pacientes que foram recrutadas e haviam realizado a avaliação da DMO em período superior a seis meses a avaliação foi realizada novamente no Hospital São Paulo, caso contrário o exame realizado anteriormente era utilizado.

\subsubsection{Avaliação da composição corporal}

Para avaliação da composição corporal foi empregada a densitometria de corpo total, pelo densitômetro de dupla emissão com fonte de raio-X (GE Lunar Radiation Corporation, modelo DPX IQ, Madison, WI, USA, versão 4.7e), sendo avaliados massa magra e gordura corporal total. O local de realização do exame foi o Hospital São Paulo. As pacientes permaneceram deitadas, os braços paralelos ao corpo e com as pernas afastadas durante a execução do exame.

A obtenção da composição corporal neste método é feita pela medida de atenuação dos picos fotoeletrólitos no corpo. A estimativa do conteúdo de gordura em massa magra sem tecido ósseo é derivada a partir de uma constante de atenuação de gordura pura e de massa magra sem osso. Ao final do exame é possível quantificar a massa magra sem tecido ósseo, massa gorda e partes moles sem gordura (COSTA, 2001).

Foram avaliados valores de Massa Magra Total (MMT), valor em gramas, Massa Muscular Esquelética Total (MMET), valor em quilos, sendo a soma da massa magra das pernas e dos braços. O Índice de Massa Muscular Esquelética (IMME), que relaciona a massa magra das pernas e dos braços em quilos do indivíduo dividido pelo quadrado da estatura em metros foi calculado (BAUMGARTNER e cols., 1998), ou seja:

$$
\mathrm{IMME}=\text { Braços }+ \text { Pernas (massa magra } \mathrm{kg}) / \text { Altura }^{2}(\mathrm{~cm})
$$


Em relação à gordura corporal total é avaliada em $\mathrm{kg}$ e na forma de porcentagem de gordura corporal $(\% \mathrm{GC})$.

\subsubsection{Parâmetros bioquímicos}

Após jejum de doze horas foram coletados $20 \mathrm{ml}$ de sangue de todas as participantes do estudo para a análise dos parâmetros bioquímicos, bem como a urina de 24 horas.

As análises laboratorias foram realizadas, em sua maior parte, pelo Laboratório Central do Hospital São Paulo. As dosagens de vitamina D, IGF-1, PTH intacto, CTX sérico, FSH, LH e leptina foram realizadas pelo Laboratório Cura Imagem e Diagnóstico.

\section{Marcadores bioquímicos do metabolismo ósseo:}

- Dosagem sérica de cálcio total: método colorimetrico

- Dosagem sérica de cálcio iônico: método eletrodo íon seletivo.

- Magnésio: método colorimétrico.

- Fósforo: método fosfomolibdato UV.

- Fosfatase alcalina: método cimético enzimático/ eletroforese em gel de agarose.

- Calciúria 24h: método colorimétrico.

- Fosfatúria de 24h: método fosfomolibdato UV.

- Clearance de Creatinina: método cinético colorimétrico.

- Sódio urina 24h: método potenciométrico.

- Vitamina D (25OHD): método radioimunoensaio.

- IGF-1: método imunofluorométrico.

- PTH intacto: método imunoradiométrico.

- CTx sérico: método eletroquimioluminométrico.

\section{Avaliação Metabólica Global:}

- Glicemia de jejum: método enzimático calorimétrico.

- Ácido úrico: método enzimático calorimétrico.

- Colesterol total e frações: método Trinder.

- Triglicérides: método Trinder.

Avaliação do Perfil Hormonal:

- Dosagem sérica de leptina: método radioimunoensaio. 
- Dosagem sérica de estradiol: método eletroquimioluminométrico.

- Dosagem sérica de testosterona livre e total: método radioimunoensaio.

- Dosagem sérica de prolactina: método fluorimetrico.

- Dosagem sérica de FSH: método fluorimetrico.

- Dosagem sérica de LH: método fluorimetrico.

\section{Avaliação do Perfil Infeccioso:}

- Sorologia para vírus B: método eletroquimioluminométrico.

- Sorologia para vírus C: método eletroquimioluminométrico.

\subsubsection{Avaliação dos fatores relacionados à massa óssea}

A investigação de fatores relacionados à massa óssea foi baseado no modelo de questionário utilizado no Ambulatório de Reumatologia (ANEXO II).

\subsubsection{Avaliação do Consumo Alimentar}

Para a avaliação da dieta habitual das pacientes foi aplicado o Questionário de Freqüência Alimentar (QFA) quantitativo (Anexo III), considerando período de seis meses, juntamente com um álbum fotográfico para facilitar a visualização do tamanho das porções.

Optou-se pelo QFA devido a sua habilidade em estimar durante um período considerável de tempo a ingestão habitual, possuir um baixo custo e por ser bastante utilizado neste tipo de estudo.

O questionário utilizado é composto por 62 itens alimentares e foi validado para avaliação da ingestão alimentar de mulheres com osteoporose (PEREIRA e cols., 2008).

Para cada alimento do QFA as participantes informam a freqüência média usual de consumo nos últimos 6 meses, a respectiva unidade de tempo (diariamente, semanalmente, quinzenalmente, mensalmente, a cada 2 meses ou nunca) e qual o tamanho de sua porção individual usual (pequena, média, grande ou extragrande), auxiliada pelo álbum fotográfico. 
Os dados obtidos no QFA foram codificados e digitados duplamente, sendo convertidos em energia e nutrientes (proteína, carboidrato, lipídio, cálcio, fósforo e vitamina D),com o auxílio do software Dietsys (Dietary Analisys System), versão 4.0 desenvolvido pelo instituto do câncer dos EUA. Os nutrientes analisados foram incorporados ao software, sendo todos oriundos do United States Department of Agriculture (USDA).

São utilizados os valores propostos pelo Institute of Medicine - DRI's (19972003, 2011), para a avaliação da adequação da dieta, que estabelece as necessidades de acordo com gênero e estágios de vida para a população saudável.

A correção pela energia foi feita computando-se os resíduos de modelos de regressão, com a ingestão energética como variável independente e a ingestão dos nutrientes como variável dependente, segundo o método proposto por Willet e Stampfer (1986).

Para a avaliação do padrão alimentar os alimentos foram sistematicamente agrupados com base em semelhanças de alimentos e composição de nutrientes, reduzindo assim os 62 alimentos a 10 grupos de alimentos. Os seguintes grupos de alimentos foram formados: alimentos ricos em gordura (manteiga, margarina, óleo de oliva, óleo de soja, maionese e salada de maionese); bebidas alcoólicas (fermentadas e destiladas); bebidas não alcoólicas (café, chá e refrigerante); carnes e ovos (carne bovina, suína, aves, peixes, ovo de codorna, frango, ovo e omelete); carnes processadas (salame, salsicha e presunto); cereais e tubérculos (arroz, batata, pão, bolachas, macarrão, farinha de mandioca e farofa); doces (sobremesas, biscoitos recheados, chocolate doce gelado e açúcar), frutas e legumes (uva, banana, laranja, tangerina, mamão, maçã, pêra, melancia, melão, manga, abacaxi, goiaba, caqui, suco de frutas natural, alface, acelga, tomate, couve, espinafre, beterraba, cenoura, pepino, pimentão, berinjela, brócolis, couve-flor e legumes de sopa); feijão (feijões, ervilhas, lentilhas e soja), produtos lácteos (leite, iogurte e queijo).

$\mathrm{Na}$ aplicação do QFA é questionado o uso de suplementação pelas entrevistadas, sendo este dado posteriormente computado. 


\subsubsection{Avaliação da Atividade Física}

Para a avaliação da atividade física habitual, foi utilizado o questionário proposto por BAECKE e cols. (1982), validado para o português por FLORINDO (2004), com isso avaliou-se quatro níveis de atividade física, sendo: atividade física ocupacional (questões 1 a 8), exercício físico e atividade física de lazer (questões 13 a 16) e atividade física de locomoção (questões 13 a 16), as quais compõem a avaliação da atividade física habitual (Anexo IV).

Para a classificação da atividade física habitual, foi utilizada a fórmula proposta por BAECKE e cols. (1982), resultando em 9 escores finais. Para a classificação dos níveis de gasto energético das atividades físicas ocupacionais e das modalidades de exercícios físicos que não constavam da padronização de BAECKE e cols. (1982) foi utilizado como referência o estudo de AINSORTH e cols. (2000) que discorre sobre compêndio de classificação de gasto energético de atividades humanas.

Cálculo do questionário:

Atividade Física Ocupacional (AFO)

Escore de $\mathrm{AFO}=($ questão $1+$ questão $2+$ questão $3+$ questão 4

+questão 5 +questão 6 + questão 7 + questão 8) / 8

Cálculo da primeira questão referente ao tipo de ocupação:

Intensidade (tipo de ocupação) $=1$ para profissões com gasto energético leve ou 3 para profissões com gasto energético moderado ou 5 para profissões com gasto energético vigoroso.

\section{Exercicio Físico no Lazer (EFL)}

Cálculo da questão 9 referente a prática de esporte/exercício físico:

Intensidade (tipo de modalidade) $=0,76$ para modalidades com gasto energético leve ou 1,26 para modalidades com gasto energético moderado ou 1,76 para modalidades com gasto energético vigoroso. 
Tempo (horas por semana) $=0,5$ para menos de uma hora por semana ou 1,5 entre maior que uma hora e menor que duas horas por semana ou 2,5 para maior que duas horas e menor que três horas por semana ou 3,5 para maior que três e até quatro horas por semana ou 4,5 para maior que quatro horas por semana (determinado pela resposta das horas por semana de prática).

Proporção (meses por ano) $=0,04$ para menor que um mês, ou 0,17 entre um e três meses ou 0,42 entre quatro e seis meses ou 0,67 entre sete e nove meses ou 0,92 para maior que nove meses (determinado pela resposta dos meses por ano de prática).

Para o cálculo desta questão, os valores são multiplicados e somados: Modalidade 1 = (intensidade $\mathrm{x}$ tempo $\mathrm{x}$ proporção $)+$ Modalidade $2=($ intensidade $\mathrm{x}$ tempo x proporção).

Após o resultado deste cálculo, para o valor final da questão 9, foi estipulado um escore de 1 a 5 de acordo com os critérios especificados no Quadro 3.

Quadro 2: Critérios propostos para a classificação da prática de esporte/exercício físico de lazer em escores

\begin{tabular}{|l|c|}
\hline \multicolumn{1}{|c|}{ Valor encontrado } & Escore Correspondente \\
\hline 0 (sem exercício físico) & 1 \\
\hline Entre 0,001 até $<4$ & 2 \\
\hline Entre 4 até $<8$ & 3 \\
\hline Entre 8 até $<12$ & 4 \\
\hline$\geq 12$ & 5 \\
\hline
\end{tabular}

Fonte: Baecke e cols., 1982

Os escores das questões 10 a 12 foram obtidos de acordo com as respostas das escalas de Likert. O escore final de EFL foi obtido de acordo com a fórmula especificada abaixo:

Escore de EFL $=$ questão $9+$ questão $10+$ questão $11+$ questão $12 / 4$ 


\section{Atividade Física de lazer e Locomoção (ALL)}

Os escores das questões 13 a 16 foram obtidos de acordo com as respostas das escalas de Likert. O escore final de ALL foi obtido de acordo com a fórmula especificada abaixo:

Escore de $\mathrm{ALL}=(6$ - questão 13$)+$ questão 14 + questão 15 + questão $16 / 4$

\subsection{ANÁLISE ESTATÍSITCA}

A análise descritiva dos dados foi realizada inicialmente com o intuito de conhecer as características gerais da população: média e desvios-padrão.

A distribuição normal foi verificada por meio do teste Kolmogorov-Smirnov. Para as variáveis com distribuição normal foi aplicado o teste $t$-student para comparação de médias (duas), enquanto as variáveis categóricas foram analisadas pelo teste de associação do qui-quadrado. A correlação entre as variáveis foram avaliadas por testes paramétricos e correlação de Pearson.

Os modelos de regressão linear múltipla foram utilizados a fim de identificar fatores associados com a EDMO, utilizada como variável dependente. As características gerais e clínicas, dados de consumo alimentar, escore de atividade física, medidas da composição corporal, concentrações dos parâmetros bioquímicos foram consideradas como independentes. Valor de $\mathrm{p}<0,05$ foi considerado como significante.

A análise fatorial exploratória dos dez grupos de alimentos foi utilizada para a avaliação dos padrões alientares. Os dados foram verificados usando o KaiserMeyer-Olkin (KMO) de medição da adequabilidade da amostra e o teste de esfericidade de Barlett (BTS), o qual testa a presença de correlações entre as variáveis.

Todas as análises foram realizadas com o auxílio do Statistical Package for the Social Sciences, versão 16.5 para Windows (SPSS Inc, Chicago, IL). 


\subsection{ASPECTOS ÉTICOS}

Este trabalho foi aprovado pelo Comitê de Ética em Pesquisa (COEP) da Faculdade de Saúde Pública da Universidade de São Paulo de acordo com as diretrizes e normas que regulamentam as pesquisas envolvendo seres humanos, aprovada pela resolução $n^{\circ} 196$, de 10 de outubro de 1996, do Conselho Nacional de Saúde. Protocolo de pesquisa n 0170/09 (Anexo V). 
5. RESULTADOS

Artigo 1:

"High Bone Mineral Density and Bone Heatlh"

Artigo de revisão

Publicado na Endocrinologia y Nutricion 


\title{
ENDOCRINOLOGÍA Y NUTRICIÓN
}

www.elsevier.es/endo

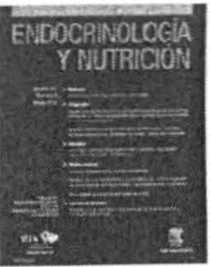

ELSEVIER

DOYMA

\section{SHORT REVIEW}

\section{High bone density and bone health}

\author{
Karin Sedó Sarkis ${ }^{a}$, Marcelo de Medeiros Pinheiro ${ }^{b}$, Vera Lúcia Szejnfeld ${ }^{b}$, \\ Lígia Araújo Martini ${ }^{\text {a.* }}$
}

a Nutrition Department, School of Public Heaith, Sao Paulo University, Brazil

bheumatology Division, Universidade Federal of Săo Paulo, Brazil

Received 1 July 2011; accepted 24 October 2011

Available online 9 February 2012

\section{KEYWORDS}

Bone and bones;

Diet;

Bone density

\section{PALABRAS CLAVE}

Hueso y huesos;

Dieta;

Densidad ósea

\begin{abstract}
The aim of this paper is to review the main aspects related to high bone density ( $\mathrm{HBD})$ as well as to discuss the physiologic mechanisms involved in bone health. There are still no well-defined criteria for identification of individuals with HBD and there are few studies on the topic. Most studies demonstrate that overweight, male gender, black ethnic background, physical activity, calcium and fluoride intake and use of medications such as statins and thiazide diuretics play a relevant and positive role on bone mineral density. Moreover, it is known that individuals with certain diseases such as obesity, diabetes, estrogen receptor-positive breast or endometrial cancer have greater bone density than healthy individuals, as well as athletes having higher bone density than non-athletes does not necessarily mean that they have healthy bones. A better understanding of risk and protective factors may help in the management of patients with bone frailty and have applicability in the treatment and in the prevention of osteoporosis, especially intervening on non-modifiable risk factors.

○ 2011 SEEN. Published by Elsevier España, S.L. All rights reserved.
\end{abstract}

\section{Densidad ósea elevada y salud ósea}

Resumen El objetivo de este artículo es revisar los aspectos principales relacionados con la Densidad Ósea Elevada (DOE) y analtzar los mecanismos fisiológicos implicados en la salud ósea. No existen aún criterios bien defínidos que sirvan para identificar a los individuos con DOE, y los estudios sobre el tema son escasos. La mayoria de los estudios demuestran que el exceso de peso, el sexo masculino, la raza negra, la actividad física, la ingesta de calcio y fluor y el uso de medicamentos como las estatinas y los diuréticos tiazidicos desempeñan un papel relevante y positivo en la Densidad Mineral Ósea (DMO). Además, se ha observado que los individuos con enfermedades tales como obesidad, diabetes, cáncer de mama positivo para receptores de estrógenos o cáncer del endometrio tienen mayor DMO que los individuos sanos; del mimo modo, se observa una mayor DMO en atletas frente a los que no lo son, sin que

\footnotetext{
- Corresponding author.

E-moil oddress: Imartini@usp.br (L. Araujo Martini).
}

1575-0922/S - see front matter 2011 SEEN. Published by Elsevier España, S.L. All rights reserved. doi: $10.1016 /$ j.endonu. 2011.10 .010 
ello necesariamente sea sínónimo de salud ósea. Un mejor entendimiento de los factores de riesgo y de protección podría ayudar a mejorar el tratamiento de los pacientes con fragilidad ósea $\mathbf{e}$ incidir en la prevención de la osteoporosts, especialmente en los factores de riesgo no modificables.

- 2011 SEEN. Publicado por Elsevier España, S.L. Todos los derechos reservados.

\section{Introduction}

The high prevalence of osteoporosis and fractures due to bone fraitty worldwide underscores the importance of seeking new prevention and treatment strategies,' such as the identification of factors involved in the increase of bone mineral density (BMD) for possible applicability in high risk populations. Few studies have addressed the prevalence of high BMD or the main clinical and laboratory aspects of individuals with high BMD. Most of these studies indicate that the following factors seem to have a positive influence on bone density: anthropometric factors (weight and body mass index [BM]] above $30 \mathrm{~kg} / \mathrm{m}^{2}$ ), ${ }^{2}$ demographic factors (male gender, black ethnic background), ${ }^{3}$ genetic factors (LRP 5 mutations), ${ }^{4}$ healthy lifestyle habits (regular physical activity, ${ }^{5}$ calcium intake above $1500 \mathrm{mg} /$ day $)^{6}$ and use of medications such as statin ${ }^{7}$ and thiazide diuretics. ${ }^{8}$ Moreover, individuals with certain diseases as obesity, estrogen receptor-positive breast or endometrial cancer, 9,10 and type II diabetes" have greater BMD than that of healthy individuals and among healthy subjects as athletes have greater bone density than non athletes. ${ }^{2}$ Based on the items addressed in the studies cited above, the aim of this paper is to review and discuss the aspects related to high $\mathrm{BMD}$ and to bone health.

\section{High bone mineral density}

The occurrence of high bone density (HBD) has been described in the literature in the last ten years. However, yet there are no well-defined criteria for adequate and precise identification of HBD. In 1994, the World Health Organization defined criteria to charactertze normal and low bone density (osteopenia and osteoporosis). ${ }^{13}$ However, there is currently no consensus on the cutoff point for the definition of individuals with high BMD.

A cohort study involving more than 1800 women'14 sug gests that the cutoff point for high BMD is $1.209 \mathrm{~g} / \mathrm{cm}^{2}$ for the femoral neck and $1.228 \mathrm{~g} / \mathrm{cm}^{2}$ for the lumbar spine (upper quartiles). Assessing more than ninety six thousand bone densitometry exams, Gregson et al. ${ }^{15}$ defined Z-score equal to or greater than 3.5 standard deviations for spine and/or hip for the characterization of such individuals; based on this criterion, only 169 individuals with HBD were found (approximately $0.2 \%$ of the overall sample). Beginning with the premise that a $T$-score less than or equal to -2 standard deviations indicates low bone density and so a greater risk for fractures, it is reasonable to assume that a $T$-score above +2 standard deviations in the absence of fractures or diseases known to affect bone quality to define $\mathrm{HBD}$.

However, there is no reference in these definitions regarding the relation between high bone mass and bone health reflected by a lower rate of stress or bone frailty fractures and better bone quality and strength. In other words, it is not known if higher BMD is truly associated with bone healthy.

The main factors associated to HBD are unknown. ${ }^{4}$ Genetic, mechanical, environmental, nutritional and endocrine factors are among the determinants related to the acquisition peak bone mass, to bone health and potential factors associated with $\mathrm{HBD}$ are discussed below.

\section{Genetic factors}

Genetic factors account for $75-80 \%$ of the variation in bone mass peak. ${ }^{16}$ An increase in bone mass may be caused by rare (often hereditary) osteochondrodysplasias and a variety of dietetic, metabolic, endocrine, hematological, infectious and neoplastic disorders. ${ }^{17}$

Low-density lipoprotein receptor-related protein 5 (LRP5) gene mutations and some other mutations are among the most studied genetic factors.

LRP5 is involved in the Wht canonical signaling pathway, in which it acts as a coreceptor and regulator of the intracellular signaling of $\beta$-catenin. Expressed in various tissues, LRP5 is considered a key protein for the physiology of bone tissue as well as in different pathological processes that include bone formation or neoformation. ${ }^{18}$ Mutations in the LRP5 gene are responsible for bone abnormalities, such as high bone mineral density and osteoporosis-pseudoglioma syndrom.4

Genetic mutations and gene polymorphisms may cause either positive or negative phenotype modifications in bone tissue. Thus, it is of clinical importance to know whether an excess in expression or gain in function of a particular gene, such as VDR, could be associated to high BMD or to a lesser risk of fractures.

\section{Non-genetic factors}

Non-genetic factors account for $20-25 \%$ of peak bone mass and may change over time. The main modifiable factors and physiopathogenic mechanisms suggested for health and increase in bone mineral density are displayed in Table 1.

Details on the positive influence of these factors on bone tissue are provided below.

\section{Anthropometrics and body composition}

The vast majority of studies include body weight as a positive factor for bone density with $10-20 \%$ of the variation in bone density related with high BMI. ${ }^{19}$ In a cohort study carried out with more the sixteen thousand women over 
Table 1 Modifiable risk and protection factors and physiopathogenic mechanisms proposed to explain the association between high bone density and bone health.

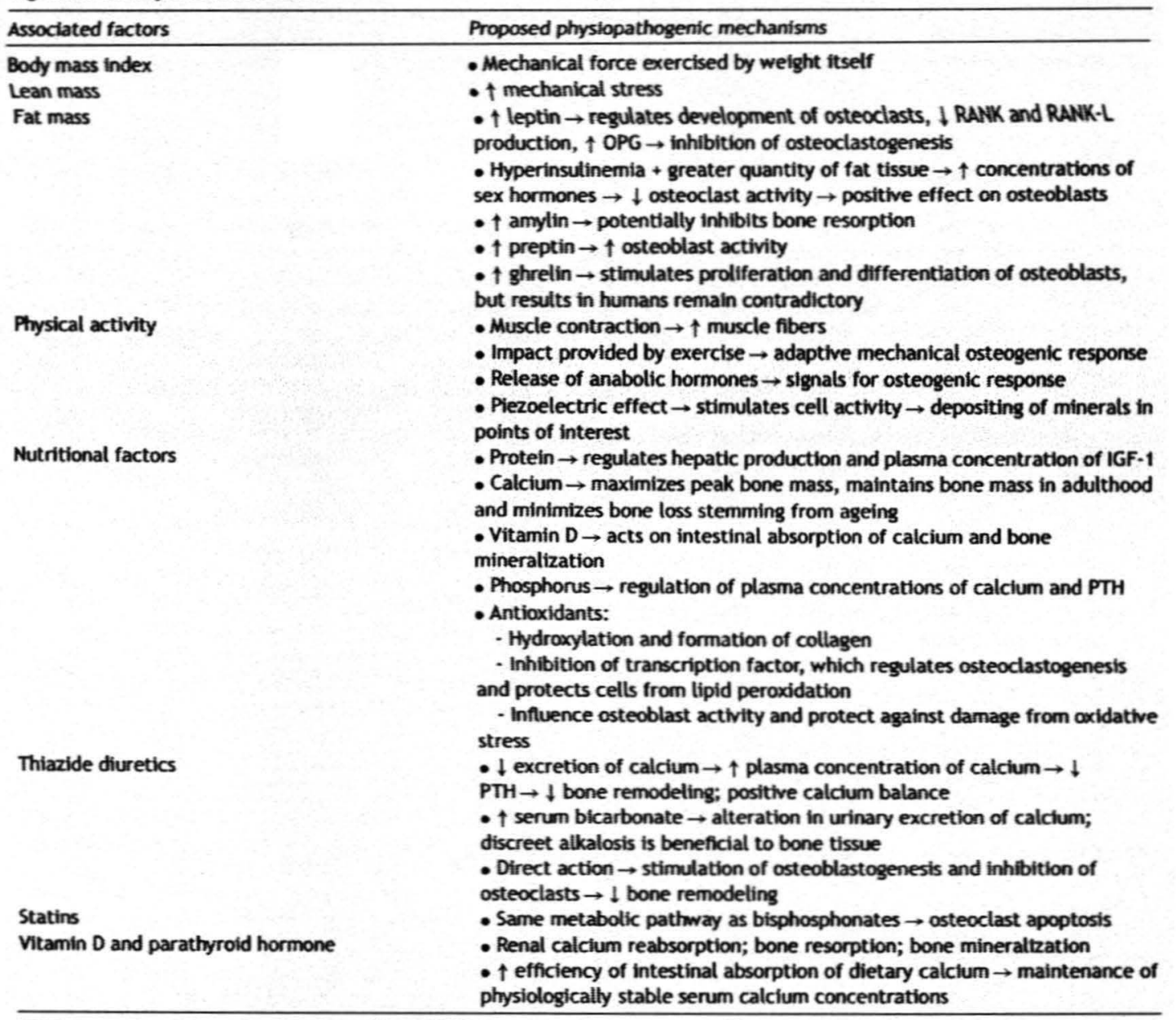

RANIK: receptor activator of nuclear factor KB; RANK-L: receptor activator of nuclear KB tigand; OPG: osteoprotegerin; IGF-1: insulin-like growth factor; PTH: parathyroid hormone.

50 years of age, Morin and Leslie $\mathrm{e}^{20}$ found that the proportion of women with high BMD increased significantly with BMI and that low BMI was associated to a greater risk of low bone density and osteoporotic fractures. ${ }^{21}$ With regard to body composition, an increase in lean mass in respect to fat mass leads to an increase in muscle strength and stimulates bone formation (osteoblasts and osteocytes) through mechanical stress." According to most authors, the higher proportion of lean mass is the main determinant of bone density. ${ }^{22.23}$ and adipose mass contributes in a less important manner.

Regarding the role of fat tissue on bone cells, it is speculated that one of the main implicated physiopathogenic mechanisms is an increase in serum concentrations of leptin, which is a hormone secreted by adipocytes that directly inhibits osteoclastogenesis vio the RANK/RANKL/OPG system. Leptin also acts indirectly through the hypothalamus, especially by decreasing in bone formation rate. Moreover, in obese individuals, there is an increase in the secretion of pancreatic hormones (insulin, preptin and amylin), which have a positive effect on bone tissue. Hyperinsulinemia associated to a greater amount of fat tissue results in several abnormalities, such as increased ovarian production of estrogen and reduced hepatic synthesis of sex-hormone binding proteins. Amylin is secreted together with insulin and inhibits bone resorption, while preptin increases osteoblast activity, especially in obese individuals. ${ }^{10}$ Ghrelin is mostly synthesized by cells of the gastric fundus and is able to stimulate the proliferation and the differentiation of osteoblasts ${ }^{25}$ as well as to activate osteoclastogenesis during periods of fasting in animal models. These results are contradictory in humans, where 
ghrelin levels are being closely related to BMD in adolescent women, but the same may not occur in older men and women. ${ }^{10}$

Is important to stand out the fat mass contributed in a less important manner than lean mass to bone formation, since it is frequently associated with other metabolic disorders such as diabetes, cardiovascular diseases and some neoplasms.

\section{Ethnic background}

African American women have greater bone mass compared with Caucasian women. ${ }^{24}$ Greater renal resorption of calcium and resistance to PTH is one of the main mechanisms proposed for this finding. ${ }^{25}$ Moreover, the higher lean mass observed in African American, especially related to muscle modulation by traction (biomechanical force), might be associated with lower risk of fractures in both genders. ${ }^{26}$

\section{Physical activity}

The benefits of physical activity on bone mass are widely recognized, particularly the effect on muscle contraction (recruitment and activation of muscle fibers) ${ }^{5}$ with the impact on bone cells, which favors periosteal apposition (adaptive mechanical response) and release of osteoanabolic hormones, such as growth hormone, insulin-like growth factor (IGF-1), estrogen and PTH. ${ }^{27}$ Besides, strainrelated adaptation is essential for normal bone development and regulation of strength in relation to exercise.

It is well known that the mechanical loads can stim. ulate responses from osteocytes and bone lining cells. Osteocytes probably do not respond directly to mechanical strain (deformation) of bone tissue, but respond indirectly to extracellutar fluid flow caused by loading. Osteocytes exposed to nuid shear stress release several messengers, including prostaglandins and nitric oxide. ${ }^{28}$ Osteoblasts also secrete these substances, as well as they express several growth factors. Mechanical stimuli can also affect osteoclasts, but this effect appears to be indirect. Loading increases hydrostatic pressure within the bone marrow, which may induce a decrease in osteoclast differentiation through marrow stromal cells participation. When exposed to strain, preosteoblastic marrow stromal cells reduce expression of RANK-L, which in turn decreases osteoclast number. ${ }^{29}$ Consequently, cells of osteoblastic lineage appear to be mediators of the suppressive effects of mechanical stimuli on bone resorption. 30

Mechanical stress also improves bone strength by influencing collagen alignment as new bone is being formed. Cortical bone tissue located in regions subject to predominantly tensile stresses has a higher percentage of collagen fibers aligned along the bone's long axis.

In regions of predominant compressive stresses, collagen fibers are more tikely to be aligned transverse to the long axis. ${ }^{31}$

These aspects have been demonstrated along with an increase in osteocalcin and $\mathrm{N}$-terminal propeptide of type 1 procollagen (PINP) ${ }^{32}$ and greater bone density in highperformance athletes (resistance and impact activities), ${ }^{12}$ although with contradictory results depending on the type of training used on women in the pre-menopause and postmenopause periods. ${ }^{33}$

In a review article, Wallace and Cumming ${ }^{34}$ demonstrate the positive effects of physical activity (exercises with and without impact - running and weight lifting, respectively) on vertebral bone density. Aquatic activities, however, such as swimming and water aerobics, do not offer consistent benefits to bone health. ${ }^{35}$

The American College Sports of Medicine (ACSM) suggests that an increase in bone density occurs in adults only with high-intensity aerobic and resistance exercises. The frequency varies in accordance with the modality. The ACSM recommends three to five sessions of impact exercises a week and two to three sessions of resistance exercises, with each session lasting 30-60 min. ${ }^{36}$

\section{Nutritional factors}

While there is evidence regarding the association between bone mass and inadequacy of micro and macronutri. ents, there are few studies that relate dietary intake to HBD.

Protein

Protein is a primary component of bone tissue and has an osteoanabolic effect, mainly in individuals with adequate calcium intake. Dietary protein regulates the hepatic production and plasma concentrations of the growth hormone and IGF-1, which are responsible for differentiation, maturation and recruitment of osteoblasts. ${ }^{37}$. While diets with protein restriction may reduce bone density, ${ }^{37}$ protein-rich diets have shown conflicting results. Hunt et al. ${ }^{38}$ found that an increase in IGF-1 following the ingestion of proteins had a beneficial effect on bone metabolism. However, it should be pointed out that increase in protein intake also led to a greater kidney excretion of calcium and could therefore have a negative effect on bone density, ${ }^{39}$ which may be minimized when there is adequate calcium and vitamin D intake..$^{40}$

\section{Calcium and vitamin $D$}

Calcium is the most abundant mineral in the organism and nearly $99 \%$ is found in the bones and teeth. Calcium is involved in biological functions, such as muscle contraction, mitosis, blood coagulation, mineral reserves and homeostasis, synapses and structural support." In bone tissue, calcium is extremely important for maximizing peak bone mass and maintaining it throughout adult life and for minimizing bone loss during ageing. ${ }^{42}$

Data obtained by dietary survey in regions of the State of São Paulo, Brazil, demonstrated that mean calcium intake was low for age and gender $(483 \mathrm{mg} /$ day for women and $410 \mathrm{mg} /$ day for men). ${ }^{43}$ This low intake was also demonstrated in the Brazilian Osteoporosis Study (BRAZOS), which describes a mean per capita intake of $400 \mathrm{mg} /$ day, ${ }^{44}$ with statistically significant differences between regions of the country, genders and age groups. According to Pereira et al., ${ }^{45}$ the main reasons for this low calcium intake are the high cost of the main food sources as well as regional, cultural and dietary habits. 
Moreover, the bioavailability of calcium is dependent on exogenous factors, such as phytates, oxalates, tannins and sodium, which play a negative role in absorption, and on endogenous factors, such as age, physiological conditions and hormonal regulation. On the other hand, oligosaccharides may maximize calcium absorption, as these molecules increase intestinal fermentation and the production of short-chain fatty acids able to acidify the medium and to stimulate the calcium absorption. ${ }^{45}$ It is also important to hightight the role of vitamin $D$ in increasing absorption of this mineral. ${ }^{46}$ However, no study has yet demonstrated the relation between dietary calcium and high BMD.

\section{Phosphorus}

Phosphorus is essential for bone formation and highly related to concentrations of calcium and PTH. A high phospho rus intake, together with low calcium intake, may alter mineral and bone metabolism due to increase in the secretion of $\mathrm{PTH}^{47}$ and greater gene expression of RANK/RANKL with a consequent stimulus of osteoclastogenesis. ${ }^{48}$ Pin heiro et al. ${ }^{44}$ found that each $100 \mathrm{~g}$ of phosphorus ingested increased the risk of fracture by $9 \%$. However, diets with phosphorus restriction do not promote increase of bone min eral density. Indeed, they may cause a negative phosphorus balance, thereby leading to greater bone loss. Thus, ade. quate intake of phosphorus and calcium is essential to bone mineralization.

\section{Antioxidants}

Antioxidants from the diet, such as selenium, vitamin $C$ and vitamin $E$, are capable of reducing the adverse effects of reactive oxygen species (ROS) on cell physiology. 49

Formation of ROS is an unavoidable outcome of tife in an oxygen-rich environment and occurs primarily in the mitochondria from the escape of electrons passing through the electron transport chain during aerobic metabolism. ${ }^{50}$ ROS are also generated during fatty acid oxidation or in response to external stimuli, such as inflammatory cytokines, growth factors, environmental toxins, chemotherapeutics, UV light, or ionizing radiation and is associated with ageing, diabetes, atherosclerosis and osteoporosis. ${ }^{51}$

Several in vitro studies and animal models have demon. strated that oxidative stress has an important impact on the differentiation and function of osteoclasts ${ }^{52,53}$ as well as the pathogenesis of bone loss. 54

Osteoporotic women have low plasma concentrations of vitamin $E,{ }^{53}$ which together with low intake of this antioxidant may increase the risk of fractures among smokers. In contrast, the high consumption of fruits and vegetables has a positive effect on bone mass, ${ }^{55}$ although no studies have demonstrated its association with high BMD.

\section{Diseases}

One could assume that higher BMD could be related to greater bone strength and lower fracture risk and, thus, better bone health. However, several diseases are associated with BMD values above normal limits, as some estrogen receptor-dependent cancers and other genetic diseases such as osteopetrosis, osteosclerosis and van Buchem disease. Studies have demonstrated a significant association between high BMD and estrogen receptor-positive breast and endometrial cancer. 9,56 Assessing more than 1500 elderly women. Ganry et al. ${ }^{56}$ found that those with femoral neck bone density above $0.769 \mathrm{~g} / \mathrm{cm}^{2}$ had a two-fold greater risk of breast cancer. The main mechanisms involved are greater serum concentrations and estrogen's gene polymorphism. ${ }^{57}$

There is also an association of HBD with obesity, due to the mechanical strength exercised by weight itself as well as the release of hormones from fat tissue (peripheral conversion of female hormones, ${ }^{10}$ low concentrations of sex hormone-binding globulin ${ }^{58}$ and hyperinsulinemia or peripheral resistance to insulin ${ }^{11}$ ). Generally, diabetic patients have higher BMD than nondiabetic one. However, they also have higher prevalence of fractures. ${ }^{59}$ Some explanations suggest higher risk of falling and poor bone quatity due to accumulation of advanced glycation end products (AGEs) on bone tissue. ${ }^{60-62}$ This is a clear situation where high BMD does not prevent fractures. Moreover, structural alterations, such as osteoarthritis and disco-arthrosis of the spine or hip, can artificially increase bone density in these skeletal sites. This aspect should be considered in interpreting high BMD, especially in elderly individuals and patients with chronic and degenerative inflammatory joint diseases. ${ }^{63}$

\section{Drugs}

Several drugs have harmful effects on bone density, such as glucocorticosteroids, aromatase inhibitors, GnRH analogues, heparin and anticonvulvants. On the other hand, some medications are related to potential positive effect, such as thiazide diuretics and statins.

Thiazide diuretics are used for treating hypertension, idiopathic hypercalciuria and other conditions. ${ }^{64}$ Randomized clinical trials have demonstrated higher bone density ${ }^{64}$ and lower fractures rate ${ }^{8}$ in current users versus non-users. These medications promote positive balance of calcium. ${ }^{65}$ Besides, these drugs can also directly stimulate osteoblasts, regardless of their effects on the kidneys. ${ }^{66}$

Statins have shown conflicting results ${ }^{67}$ primarily due to the pharmacokinetic and pharmacodynamic differences between them, such as hydrophilic (simvastatin and lovastatin) or lipophilic (pravastatin, atorvastatin and fuvastatin) characteristics. ${ }^{68}$ Studying post-menopausal women with low bone density, Tanriverdi et al. have reported the synergic densitometric effect of atorvastatin when associated with bisphosphonates. ${ }^{7}$

However, Rejnmark found no significant differences in bone density of 82 postmenopausal women after 12 months follow-up. ${ }^{69}$ Bone density is apparently unaltered by the use of simvastatin, pravastatin and atorvastatin. ${ }^{70}$ Among those in which an important increase in bone density was found, there are reports of a longer administration of atorvastatin. ${ }^{71}$ However, data on the anti-fracture ability of these drugs remain inconsistent, ${ }^{68}$ although they have been shown to decrease biochemical bone markers. ${ }^{7,73}$

Simvastatin may enhance osteoblastogenesis through the stimulus of the production of bone morphogenetic protein $(B M P-2)^{74}$ and reduce osteoclastogenesis through inhibited production of farnesyl-diphosphate synthase. ${ }^{75}$ 


\section{Hormone profile}

Hormonal alterations play an important role on mineral and bone metabolism. ${ }^{*}$

Hormones related to obesity, such as leptin and pancreatic hormones, were discussed eartier.

Vitamin $\mathrm{D}$ and parathyroid hormone are discussed below.

Vitamin D and parathyroid hormone

Vitamin D and parathyroid hormone (PTH) are fundamental regulators of mineral and bone metabolism, especially with regard to intestinal absorption and renal resorption of calcium as well as bone formation and resorption. ${ }^{46}$ Dietary vitamin $D$ intake and adequate exposure to sunlight are necessary for the maintenance of plasma concentration of $25(\mathrm{OH}) \mathrm{D} .{ }^{3}$ There are few food sources that contain vitamin $D$ and in spite of what occurs in other countries there is no dietary fortification in Brazil. Environmental (latitude, season of the year, ozone layer and cloud cover) and personal (skin type, clothing and use of sun block) factors are involved in the serum level of vitamin D and bone health. Deficiency of vitamin $D$ causes secondary hyperparathyroidism and higher bone loss. ${ }^{76}$

\section{Sex hormones}

Gonadotropin-releasing hormone (GnRH) is secreted by the hypothalamus and stimulates the secretion of the folliclestimulating hormone (FSH) and luteinizing hormone ( $\mathrm{LH}$ ) in the anterior pituitary. In women, these hormones stimulate the ovarian production of estrogen and progesterone and inhibin which, in turn, regulates secretion of GnRH, FSH and LH through a feedback mechanism. ${ }^{n}$ The loss of this mechanism, such as in menopause (hypoestrogenism), increases the plasma concentrations of FSH and $\mathrm{LH}$, which have a negative effect on bone tissue. ${ }^{78}$

Several authors have demonstrated that a serum increase in FSH and reduction in inhibin lead to bone loss in perimenopausal women. ${ }^{\pi}$ in contrast, a reduction in FSH is closely related to a gain in bone mass. ${ }^{79}$ Assessing 699 healthy Chinese women between 20 and 82 years of age (464 in the pre-menopause period), $\mathrm{Xu}$ et al. ${ }^{77}$ found that an increase in FSH and $\mathrm{LH}$ of $10 \mathrm{UI} / \mathrm{L}$ was associated to a $5.5 \%$ and $4.4 \%$ reduction in spine BMD, respectively. FSH has recently been reported to regulate bone metabolism through the direct and indirect stimulations of osteoclasts. ${ }^{80,81}$ it also stimulates the production of TNF- $\alpha$, with a consequent greater activation of osteoclastogenesis. ${ }^{82}$ The role of $\mathrm{LH}$ in bone tissue remains unknown, but it is speculated that it may induce an increase in androgens. ${ }^{81}$

\section{Lipid profile}

Epidemiological studies investigate the association between low bone density and higher cardiovascular mortality, concomitant medication, associated diseases and traditional risk factors. ${ }^{83,84}$ Although results are contradictory, several authors speculate the negative association between bone mass and hypercholesterolemia. ${ }^{83-85}$ in vitro studies have shown that products from the oxidation of lipids and lipoproteins inhibit the differentiation and function of osteoblasts ${ }^{85,86}$ probably mediated by the mevalonate pathway. ${ }^{8}$

\section{Conclusions and implications}

Considering the lack of available information on associated protective factors, further studies are needed in order to allow a better understanding of the clinical aspects and physiopathogenic mechanisms associated with higher BMD and bone health. A better understanding of these factors could be an important strategy for the implementation of prevention and treatment measures for patients with bone frailty especially related to osteoporotic fractures.

\section{Sources of funding}

Conselho Nacional de Desenvolvimento Cientifico e Tec. nológico (CNPq), process number 470862/2009-2.

\section{Conflict of interest}

The authors have no conflict of interest to declare.

\section{References}

1. Harvey N, Dennison E, Cooper C. Osteoporosis: impact on health and economics. Nat Rev Rheumatol. 2010;6:99-105.

2. Orwoll ES, Bevan L, Phipps KR. Determinants of bone mineral density in older men. Osteoporos int. 2000;11:815-21.

3. Tershakovec AM, Kuppler KM, Zemel B, Stallings VA. Age, sex, ethnicity, body composition, and resting energy expenditure of obese African American and white children and adolescents. Am J Clin Nutr. 2002;75:867-71.

4. Whyte MP, Reinus WH, Mumm S. High-bone-mass disease and LRP5. N Engl J Med. 2004;3509:2096-9.

5. Cadore EL, Brentano MA, Kruel LFM. Efeitos da atividade física na densidade mineral óssea e na remodelaçáo do tecido ósseo. Rev Bras Med Esporte. 2005;11:373-9.

6. Heaney RP, Recker RR, Stegman MR, Moy AJ. Calcium absorption in women: relationships to calcium intake, estrogen status, and age. J Bone Miner Res. 1989;4:469-75.

7. Tanriverdi $H A$, Barut A, Sarikaya S, Statins have additive effects to vertebral bone mineral density in combination with risedronate in hypercholesterolemic postmenopausal women. Eur J Obstet Gynecol Reprod Biol. 2005;120:63-8.

8. Otmos JM, Hernández $\Omega$, Martínez $J$, Castillo J, Valero $C$, Pérez Pajares $\mathrm{I}$, et al. Bone tumover markers and bone mineral density in hypertensive postmenopausal women on treatment. Maturitas. 2010;65:396-402.

9. Chen Z, Arendell L, Aickin M, Cauley J, Lewis CE, Chlebowski R, Women's Health Initiative Program, National Heart, Lung and Blood Institute, US Department of Health and Human Services. Hip bone density predicts breast cancer risk independently of Gail score: results from the Women's Health initiative. Cancer. 2008;113:907-15.

10. Reid IR. Relationships between fat and bone. Osteoporos int. 2008;19:595-606.

11. Yamaguchi $T$, Kanazawa I, Yamamoto $M$, Kurioka S, Yamauchi $M$, Yano S, et at. Associations between components of the metabolic syndrome versus bone mineral density and verte bral fractures in patients with type 2 diabetes. Bone. 2009;45: 174-9.

12. Trutschnigg B, Chong C, Habermayerova L, Karelis AD, Komorowski J. Female boxers have high bone mineral den sity despide low fat mass, high energy expenditure, and 
high inidence of oligomenormea. Appl Physiol Nutr Metab. 2008;33:863-9.

13. National Osteoporosis Foundation (NOF). NOF clinician's guide to prevention and treatment of osteoporosis. Washington, $D C$ National Osteoporosis Foundation; 2008.

14. Pesonem J, Sirola J, Tuppurainen $M$, Jurvelin J, Athava $E$, Honkanen $R$, et al. High bone mineral density among perimenopausal women. Osteoporos int. 2005;16:1899-906.

15. Gregson CL, Rittweger J, Lazar V, Steel S, Tobias JH. The high bone mass phenotype is charactertzed by increased trabecular density and reduced endosteal expansion. ASBMR; 2009.

16. Heaney RP, Abrams S, Dawson-Hughes B, Looker A, Marcus R, Matkovic V, Weaver C. Peak bone mass. Osteoporos Int. 2000;11: 985-1009.

17. White MP. Sclerosis bone disorders. In: Primer on the metabolic bone disease and disorders of mineral metabolism. 7th ed. Washington: The Sheridan Press; 2008. p. 412-23.

18. Kato M, Patel MS, Levasseur R, Lobov I, Chang BH, Glass 2 nd $D A$, et al. Cbfa1-independent decrease in osteoblast prolifera tion, osteopenia, and persistent embryonic eye vasculartzation in mice deficient in Lrp5, a Wnt coreceptor. J Cell Biol. 2002;157:303-14.

19. Reid IR. Relationships among body mass, its components, and bone. Bone. 2002; 31:547-55.

20. Morin S, Leslie WD. Manitoba Bone Density Program, High bone mineral density is associated with high body mass index. Osteoporos Int. 2009;20:1267-71.

21. Morin S, Tsang JF, Lestie WD. Weight and body mass index predict bone mineral density and fractures in women aged 40 to 59 years. Osteoporos int. 2009;20:363-70.

22. Ilich-Emst J, Brownbill RA, Ludemann MA, Fu R. Critical factors for bone health in women across age span: how important is muscle mass? Medscape Womens Health. 2002;7:2

23. Genaro PS, Pereira GA, Pinheiro MM, Szejnfeld Vh, Martini LA. Influence of body composition on bone mass in postmenopausal osteoporotic women. Arch Gerontol Geriatr. 2010;51:295-8.

24. Aloia JF, McGowan DM, Vaswani AN, Ross P. Cohn SH. Relationship of menopause to skeletal and muscle mass. Am J Clin Nutr. 1991;53:1378-83.

25. Kleerekoper $M$, Nelson DA, Peterson EL, Flynn MJ, Pawluszika AS, Jacobsen G, et al. Reference data for bone mass, calciotropic hormones, and biochemical markers of bone remodeling in older (55-75) postmenopausal white and black women. J Bone Mine Res. 1994;9:1267-76.

26. Hochberg $M$. Racial differences in bone strength. Trans Am Clin Climatol Assoc. 2007;118:305-15.

27. Borer KT. Pfysical activity in the prevention and amelioration of osteoporosis in wornen: interaction of mechanical, hormonal, and dietary factors. Sports Med. 2005;35:779-830.

28. Burger EH, Klein-Nulend J. Mechanotransduction in bone role of the lacuno-canalicular network. FASEB J. 1999;13 Suppl.:S101-12.

29. Rubin J, Murphy T, Nanes MS, Fan X. Mechanical strain inhibits expression of osteoclast differentiation factor by murine stromal cells. Am J Physiol Cell Physiol. 2000;278:C1126-32.

30. Robling AG, Castillo $A B$, Turner $C H$. Biomechanical and molecutar regulation of bone remodeling. Annu Rev Biomed Eng. 2006;8:455-98.

31. Riggs CM, Lanyon LE, Boyde A. Functional associations between collagen fibre orientation and locomotor strain direction in cortical bone of the equine radius. Anat Embryol. 1993;187: 231-8.

32. Adami S, Gatti D, Viapiana O, Fiore CE, Nuti R, Lutsetto G, et al.; BONTURNO Study Group. Ptysical activity and bone turnover markers: a cross-sectional and a longitudinal study. Calcif Tissue Int. 2008;83:388-92.

33. Bassey EJ, Rothwell MC, Littlewood JJ, Pye DW. Pre- and postmenopausal women have different bone mineral density responses to the same high impact exercise. J Bone Miner Res. 1998; 13:1805-13.

34. Wallace BA, Cumming RG. Systematic review of randomized trials of the effect of exercise on bone mass in pre- and postmenopausal women. Calctif Tissue int. 2000;67:10-8.

35. Emslander $\mathrm{HC}$, Sinaki $M$, Muhs $\mathrm{M}$, Chao $\mathrm{EY}$, Wahner $\mathrm{HW}$, Bryant SC, et al. Bone mass and muscle strength in female college athletes (runners and swimmers). Mayo Clin Proc. 1998; 73:1151-60.

36. American College of Sports Medicine (ACSM). Physical activity and bone health. Med Sci Sports Exerc 2004. Available from: http: $/ /$ www.acsm-msse. org [accessed 05.05.10].

37. Ammann P, Bourrin S, Bonjour IP, Meyer iM, Rizzoli R. Protein undernutrition-induced bone loss is associated with decreased IGF-1 leve's and estrogen deficiency. I Bone Miner Res. 2000;15:683-90.

38. Hunt JR, Johnson LK, Fariba Roughead ZK. Dietary protein and calcium interact to influence calclum retention: a controlled feeding study. Am J Clin Nutr. 2009;89:1357-65.

39. Heaney RP. Protein intake and the calcium econorny. J Am Diet Assoc. 1993;93:1259-60.

40. Schürch MA, Rizzoli R, Slosman D, Vadas L, Vergnaud P, Bonjour JP. Protein supplements increase serum insulin-tike growth factor-I levels and attenuate proximal femur bone loss in patients with recent hip fractures. A randomized, double-blind, placebo-controlled trial. Ann Intern Med. 1998;128:801-9.

41. Miller GD, Jarvis JK, MCBean LD. The importance of meeting calcium needs with foods. J Am Coll Nutr. 2001:2012 Suppl): $1685-855$.

42. Matkovic V, Jelic T, Wardlaw GM, liich JZ, Goel PK, Wright JK, et al. Timing of peak bone mass in Caucasian females and its implication for prevention of osteoporosis, Inference from a cross-sectional model. J Clin Invest. 1994;93:799-808.

43. Bueno MB, Cesar CL, Martini LA, Fisberg RM. Dietary calclum intake and overweight: an epidemiologic view. Nutrition. 2008;24(11-12):1110-5.

44. Pinheiro MM, Schuch NJ, Genaro PS, Ciconelli RM, Ferraz MB, Martini LA. Nutrient intakes related to osteoporotic fractures in men and women-the Brazilian Osteoporosis Study (BRAZOS), Nutr J. 2009;8:6.

45. Pereira GA, Genaro OS, Pinheiro Mu, Szejnfeld Vh, Martini LA. Cálcio Dietético - estratégias para otimizar o consumo. Rev Bras Reumatol. 2009;49:164-71.

46. Holick MF. Sunlight and vitamin D for bone health and prevention of autoimmune diseases, cancers and cardiovascular disease. Am J Clic Nutr. 2004;8016 Suppl.):16785-885.

47. Calvo MS, Kumar R, Heath H. Persistently elevated parathyroid hormone secretion and action in young women after four weeks of ingesting high phosphorus, low calcium diets. J Clin Endocrinol Metab. 1990;70:1334-40.

48. Katsumata S, Masuyama R, Uehara M, Suzuki K. High-phosphorus diet stimulates receptor activator of nuclear factor-kappaB ligand MRNA expression by increasing parathyroid hormone secretion in rats. Br J Nutr. 2005;94:666-74.

49. Institute of Medicine (IOM). Dietary reference intakes for vita$\min \mathrm{C}$, vitamin $\mathrm{E}$, selentum, and carotenoids. Washington: National Academy Press; 2000.

50. Glorgio M, Trinei M, Migtiaccio E, Pelicci PG. Hydrogen peroxide: a metabolic by-product or a common mediator of ageing signals? Nat Rer Mol Cell Biol. 2007;8:722-8.

51. Manolagas SC. From estrogen-centric to aging and oxidative stress: a revised perspective of the pathogenesis of osteoporosts. Endocr Rev. 2010;31:266-300.

52. Lean JM, Jagger CJ, Kirstein B, Fuller K, Chambers TJ. Hydrogen peroxide is essential for estrogen-deficiency bone loss and osteoclasts formation. Endoclrinology. 2005;146:728-35.

53. Maggio D, Barabani M, Pierandrei M, Polidori MC, Catani $M$, Mecocci $P$, et al. Marked decrease in plasma antioxidants in aged 
osteoporotic women: results of a cross-sectional study. J Clin Endocrinol Metab. 2003;88:1523-7.

54. Sendur OF, Turan Y, Tastaban E, Serter M. Antioxidant status in patients with osteoporosis: a controlled study. Joint Bone Spine. 2009;76:514-8.

55. Prynne CJ, Mishra GD, O'Connell MA, Muniz G, Laskey MA, Yan $\mathrm{L}$, et al. Fruit and vegetable intakes and bone mineral sta. tus: a cross sectional study in 5 age and sex cohorts. Am J Clin Nutr. 2006;83:1420-8.

56. Ganry O, Baudoin C, Fardellone P, Peng J, Raverdy N. Bone mass density and risk of breast cancer and survival in older women. Eur J Epidemiol. 2004;19:785-92.

57. Harvey LA. Re: are breast density and bone mineral density independent risk factors for breast cancer? J Natl Cancer Inst. 2005:97:778.

58. Ricci TA, Heymsfield SB, Pierson Jr RN, Stahl T, Chowdhury HA, Shapses SA. Moderate energy restriction increases bone resorption in obese postmenopausal women. Am J Clin Nutr. 2001;73:347-52.

59. Nelson DA, Jacober SJ. Why do older women with diabetes have an increased fracture risk? J Clin Endocrinol Metab. 2001:86:29-31.

60. Vashishth D, Gibson GJ, Khoury JI, Schaffler MB, Kimura J, Fyhrie DP. Influence of nonenzymatic glycation on biomechanical properties of cortical bone. Bone. 2001;28:195-201.

61. Hein G, Weiss C, Lehmann G, Niwa T, Stein G, Franke S. Advanced glycation end product modification of bone proteins and bone remodelling: hypothesis and preliminary immunohistochemical findings. Ann Rheum Dis. 2006;65:101-4.

62. Kume S, Kato S, Yamagishi S, Inagaki $Y$, Ueda S, Arima N, et al. Advanced glycation end-products attenuate human mesenchymal stem cells and prevent cognate differentiation into adipose tissue, cartilage, and bone. J Bone Miner Res. 2005;20: 1647-58.

63. Glowacki J, Tuteja M, Hurwitz S, Thornhill TS, Leboff MS. Discordance in femoral neck bone density in subjects with unilateral hip osteoarthritis. J Clin Densitom. 2010;13:24-8.

64. LaCrobx A7, Ott SM, Ichikawa L, Scholes D, Barlow WE. Low-dose hydrochlorothiazide and preservation of bone minerat density in older adults. A randomized, double-blind, placebo controlled trial. Ann Intern Med. 2000;133:516-26.

65. Lemann Jr J, Bushinsky DA, Hamm $\mathrm{U}$. Bone buffering of acid and base in humans. Am J Physiol Renal Physiol. 2003;285: F811-32.

66. Dvorak MM, De Joussineau C, Carter DH, Pisitkun T, Knepper MA, Gamba G, et al. Thiazide diuretics directly induce osteoblast differentiation and mineraltzed nodule formation by interacting with a sodium chloride co-transporter in bone. J Am Soc Nephrol. 2007;18:2509-16.

67. Rizzo M, Rini GB. Statins, fracture risk, and bone remodeling: what is true? Am J Med Sci. 2006;332:55-60.

68. Jadhav SB, Jain GK. Statins and osteoporosis: new role for old drugs. J Pharm Pharmacol. 2006;58:3-18.

69. Rejnmark L, Buus NH, Vestergaard P, Heickendorff L, Andreasen $F$, Larsen $M L$, et al. Effects of simvastatin on bone turnover and BMD: a 1-year randomized controlled trial in postmenopausal osteopenic women. J Bone Miner Res. 2004;19:737-44.

70. Maritz FJ, Conradie Mu, Hulley PA, Gopal R, Hough S. Effect of statins on bone mineral density and bone histomorphometry in rodents. Arterioscler Thromb Vasc Biol. 2001;21:1636-41.
71. Kawane T, Terashima S, Kurahashi I, Yanagawa T, Yoshida $\mathbf{H}$, Horiuchi $\mathrm{N}$. Atorvastatin enhances bone density in ovariectomized rats given 17 beta-estradiol or human parathyroid hormone (1-34). Endocrine. 2004;24:121-9.

72. Chan MH, Mak TW, Chiu RW, Chow CC, Chan IH, Lam CW. Sim vastatin increases senum osteocalcin concentration in patients treated for hypercholesterolaemia. J Clin Endocrinol Metab. $2001 ; 86: 4556-9$.

73. Stein EA, Farnier M, Waldstreicher J, Mercun M, Simvastatin/Atorvastatin Study Group. Effects of statins on biomarkers of bone metabolism: a randomised trial. Nutr Metab Cardiovasc Dis. 2001;11:84-7.

74. Ruiz-Gaspa S, Nogues X, Enjuanes A, Monllau JC, Blanch J, Carreras $R$, et al. Simvastatin and atorvastatin enhance gene expression of collagen type 1 and osteocalcin in pri mary human osteoblasts and MG-63 cultures. J Cell Biochem. 2007;101:1430-8.

75. Staal A, Frith JC, French MH, Swart J, Güngör T, Harrity TW, et at. The ability of statins to inhibit bone resorption is directly related to their inhibitory effect on HMG-COA reductase activity. J Bone Miner Res. 2003;18:88-96.

76. Kuchuk NO, van Schoor NM, Pluijm SM, Chines A, Lips P. Vitamin $D$ status, parathyroid function, bone turnover, and BMD in postmenopausal women with osteoporosis: global perspec tive. J Bone Miner Res. 2009;24:693-701.

77. Xu ZR, Wang AH, Wu XP, Zhang H, Sheng ZF, $W u X Y$, et at. Relationship of age-related concentrations of serum FSH and LH with bone mineral density, prevalence of osteoporosis in native Chinese women. Clin Chim ACta. 2009;400(1-2):8-13.

78. Perrien DS, Achenbach SJ, Bledsoe SE, Walser B, SUva LJ, Khosla S, Gaddy D. Bone turnover across the menopause transition: correlations with inhibins and folticle-stimulating hormone. J Clin Endocrinol Metab. 2006;91:1848-54.

79. Kawai $H$, Furuhashi $M$, Suganuma $N$. Serum follicle-stimulating hormone level is a predictor of bone mineral density inpa. tients with hormone replacement therapy. Arch Gynecol Obstet. 2004;269:192-5.

80. Boyle WJ, Simonet WS, Lacey DL. Osteoclast differentiation and activation Nature. 2003;423:337-42.

81. Baron R. FSH versus estrogen: who's guilty of breaking bones? Cell Metab. 2006;3:302-5.

82. Iqbal J, SUn L, Kumar TR, Blair HC, Zaid M. Follicle-stimulating hormone stimulates TNF production from immune cells to enhance osteoblast and osteoclast formation. Proc Natl Acad Sci U S A. 2006;103:14925-30.

83. Kado DM, Browner WS, Blackwell T, Gore R, Cummings SR. Rate of bone loss is associated with mortality in older wornen: a prospective study. J Bone Miner Res. 2000;15:1974-80.

84. Wu LY, Yang TC, Kuo SW, Hsiao CF, Hung YJ, Hsieh CH, et al. Correlation between bone mineral density and plasma lipids in Talwan. Endocr Res. 2003;29:317-25.

85. Parhami F, Jackson SM, Tintut Y, Le V, Balucan JP, Territo M, Demer $\mathrm{L}$. Atherogenic diet and minimalty oxidized low den sity tipoprotein inhibit osteogenic and promote adipogenic differentiation of marrow stromal cells. J Bone Miner Res. 1999;14:2067-78.

86. Tintut $\mathrm{Y}$, Morony S, Demer UL. Hyperlipidemia promotes osteoclastic potential of bone marrow cells ex vivo. Arterioscler Thromb Vasc Biol. 2004;24:e6-10.

87. Cummings SR, Bauer DC. Do statins prevent both cardiovascular disease and fracture? JAMA. 2000;283:3255-7. 
Artigo 2:

"Low fatness, reduced fat intake and adequate plasmatic concentrations of LDLcholesterol are associated with high bone mineral density in women: a crosssectional study with control group"

\section{Artigo original}

Publicado na Lipids in Health and Disease 


\section{Low fatness, reduced fat intake and adequate plasmatic concentrations of LDL-cholesterol are associated with high bone mineral density in women: a cross-sectional study with control group}

Karin 5 Sarkis, Lígia A Martini ${ }^{2}$, Vera L Szejinfeld ${ }^{3}$ and Marcelo M Pinheiro $3,4^{*}$

\section{Abstract}

Background: Several parameters are associated with high bone mineral censity (BMD), such as overweight, black background, intense physical activity (PA). greater calcium intake and some medications. The objectives are to evaluate the prevalence and the main aspects associated with high BMD in healthy women

Methods: After reviewing the database of approximately $21,500 \mathrm{BMD}$ scans performed in the metropolitan area of Sáo Paulo, Brazil from June 2005 to October 2010 , high BMD (over $1400 \mathrm{~g} / \mathrm{cm}^{2}$ at lumbar spine and/or above 1200 $\mathrm{g} / \mathrm{cm}^{2}$ at femoral neck) was found in 421 exams. Exclusion criteria were age below 30 or above 60 years, black ethnicity, pregnant $\alpha$ obese women, disease and/or medications known to interfere with bone metabolism. A total of 40 women with high BMD were included and matched with 40 healthy women with normal BMD, paired to weight, age, skin color and menopausal status. Medical history, food intake and PA were assessed through validated questionaires. Body composition was evaluated through a GE-Lunar DPX MD + bone densitometer. Radiography of the thoracic and lumbar spine was carried out to excluce degenerative aiterations or fractures. Biochemical parameters included both lipid and hormonal profiles, along with mineral and bone metabolism. Statistical analysis included parametric and nonparametric tests and linear regression models. $P<0.05$ was considered significant.

Results: The mean age was 50.9 (8.3) years. There was no significant difference between groups in relation to PA, smoking, intake of calcium and vitamin D, as well as laboratory tests, except senum C-telopeptide of type I coliagen (s-CTX). Which was lower in the high BMD group $(p=0.04)$. In the final model of multivariate regression, a lower fat intake and body fatness as well a better profile of LDL-cholesterol predicted almost $35 \%$ of high BMD in women. (adjusted $R 2=0.347 ; p<0.001$ ). In addition, greater amounts of lean mass and higher IGF-1 serum concentrations played a protective role, regardless age and weight.

Conclusion: Our results demonstrate the potential deleterious effect of lipid metabolism-related components, including fat intake and body fatness and worse lipid profle, on bone mass and metabolism in healthy women.

Keywords: Bone mineral density, Body composition, Lipic metabolism, Diet, Mineral metabolism, Women

\footnotetext{
- Correspondence mpinheropuolcombr

'Pheumatology Drision Univeridade federal de Sao Pauio/tscola Faulsta

de Necicina Urifesp/LPM, Av Dr Attino Avantes, 669. apto 105 Vila

Clementine, Sto Faulo SP, Easl CEP O4042-033

full lise of author information is availthe at the end of the article
}

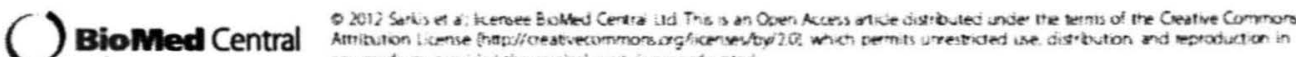

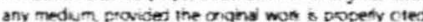




\section{Background}

In recent years, the occurrence of high bone mineral density (BMD) has been observed in some individuals [1]. However, little is known about the prevalence, physiopathogenic aspects involved, associated risk factors or the clinical relevance of this entity in medical practice, including the possibility to be a variant of normality or be considered a disease itself, since it associates with some morbidities.

So far, there is controversy about the definition of individuals with high $B M D$, since the World Health Organization [2] criteria for classification of osteopenia and osteoporosis does not consider this condition. Thus, individuals with values above one standard deviation (SD) are considered as normal, regardless of the absolute value or the number of standard deviations above the unit.

Although there are few studies on this subject, most of them point out to the role of anthropometric data (overweight and obesity) [3] and demographics (males and black ethnicity) [4], as well as genetic factors (LRP5 mutations) [5], lifestyle habits (intense physical activity [6], higher calcium intake above $1500 \mathrm{mg} /$ day and food or water with excess fluoride) $[7,8]$, as the main factors positively associated with high BMD. Some medications such as statins [9] and thiazide diuretics [10] may also have a protective effect. In addition, patients with breast and endometrial cancer [11], type II diabetes mellitus [12] and athletes have higher BMD than healthy individuals [13].

Thus, a better understanding of these aspects can help to optimize the management of patients with osteoporosis as well as minimize the burden of osteoporotic fractures throughout the world.

The objective of this study was to identify the prevalence, as well as risk factors and protection associated with high BMD in healthy women, through cross-sectional study with control group.

\section{Results}

Clinical and nutritional data (mean \pm SD) are listed in Table 1. The groups were matched for age, weight, BMI, smoking, fat mass and menopausal status. In both groups, the prevalence of overweight was high, but without significant difference between them. Nevertheless, women with high BMD had higher FFM and ALM ( $p<$ $0.05)$. Seven healthy control women (17.5\%) and three (7.5\%) of the high BMD group were classified as sarcopenic $(p=0.31)$.

In the high BMD group, the only significant correlations found were between femoral neck BMD and BF\% $(\mathrm{r}=-0.36 ; p=0.02), \mathrm{BF}(\mathrm{r}=-0.45 ; p=0.004)$ and RSMI ( $r=0.35 ; p=0.02$ ).

After the adjustment of food intake for energy, significant difference was obtained between the groups
Table 1 Anthropometric, clinical and nutritional data of the population, according to $\mathrm{BMD}$

\begin{tabular}{|c|c|c|c|}
\hline & $\begin{array}{l}\text { HBMD } \\
(\mathrm{N}=40)\end{array}$ & $\begin{array}{l}\text { Healthy controls } \\
(\mathrm{N}=40)\end{array}$ & p \\
\hline Age (years) & $50.9(8.2)$ & $51(8.5)$ & 0.989 \\
\hline Weight (kg) & $64.3(5.2)$ & $612(6.7)$ & 0.052 \\
\hline Height: (m) & $1.58(0.1)$ & $157(0.0)$ & 0241 \\
\hline $\mathrm{BM}\left(\mathrm{kg} / \mathrm{m}^{2}\right)$ & $25.6(2.4)$ & $252(2.6)$ & 0.497 \\
\hline Age of menarche fyears) & $13.0(2.4)$ & $13.0(1.4)$ & 0.913 \\
\hline Parity & $2.4(1.4)$ & $22(13)$ & 0.460 \\
\hline Smoking packets year & $16.7(19.3)$ & $262(27.7)$ & 0.290 \\
\hline IPA index (score) & $7.6(1.2)$ & $7.9(13)$ & 0.412 \\
\hline \multicolumn{4}{|l|}{ Bone Mineral Density } \\
\hline Lumbar spine $\left(\mathrm{g} / \mathrm{cm}^{2}\right)$ & $1.408(0.1)$ & $1209(0.1)$ & $<0.001$ \\
\hline T-score & $1.9(1.0)$ & $02(0.8)$ & $<0.001$ \\
\hline Zscore & $2.5(1.1)$ & $0.9(0.9)$ & $<0.001$ \\
\hline Femoral neck $\left(g / \mathrm{cm}^{2}\right)$ & $1.1190 .1)$ & $0.966(0.08)$ & $<0,001$ \\
\hline T-score & $0.9(0.9)$ & $02(0.6)$ & $<0.001$ \\
\hline Z-score & $1.7(0.6)$ & $0 .(10)$ & $<0.001$ \\
\hline To:al fermoral $\left(9 / \mathrm{cm}^{2}\right)$ & $1.166(0.1)$ & $1043(0.2)$ & $<0.001$ \\
\hline Tscore & $14(10)$ & $02(07)$ & $<0001$ \\
\hline Z-score & $1.9(1.1)$ & $0.7(0.7)$ & $<0.001$ \\
\hline \multicolumn{4}{|l|}{ Body Composition } \\
\hline FFM (kg) & $36.4\{.1\}$ & $34.4(3.9)$ & 0.029 \\
\hline ALM (kg) & $16 \div(1.9)$ & $150(1.7)$ & 0,007 \\
\hline RSM( $\left.0 \mathrm{gg} / \mathrm{m}^{2}\right)$ & $6.30 .7)$ & $6.1(0.7)$ & 0.278 \\
\hline Body fax (\%) & $39.4(6.8)$ & $405(6.0)$ & 0.433 \\
\hline Total body fax mass ( $\mathrm{kg}$ ) & $24.0(4.8)$ & $23.6(5.4)$ & 0.740 \\
\hline \multicolumn{4}{|l|}{ Dietary Intake (day) } \\
\hline Energy (ikcal) & $1697.3(4605)$ & $17493(575.9)$ & 0.653 \\
\hline Protein (g) & $74.2(10.9)$ & $67.0(11.3)$ & 0,005 \\
\hline Fat (g) & $57.6(11.9)$ & $58.8(14.9)$ & 0.700 \\
\hline Carbohidrate (g) & $235.1(30.7)$ & $238.3(36.9)$ & 0.637 \\
\hline Caicium (mg) & $8364(2498)$ & $754.7(219.7)$ & 0.124 \\
\hline Phosphorus (mg) & $1178.9(178.8)$ & $10682(153.9)$ & 0004 \\
\hline Vitamin D ( $\mu g)$ & $1.9(2.2)$ & $20(1.4)$ & 0.944 \\
\hline
\end{tabular}

BM/ Body Mass Index TFA Total Physical Activity, FFM Total Fat-Free Mass, ALM Appendicular Lean Mass, PSMI Relative Skeletal Musde index, Nutrients adjusted to energy. T- student Test

regarding the intake of protein and phosphorus, with greater levels in women with high BMD $(p<0.05)$. The mean daily consumption of lipids, carbohydrates and vitamin D was similar in both groups. The mean intake of macronutrients as well as phosphorus were within the DRI values proposed by the Food and Nutrition Board [14-16]. Conversely, the mean calcium and vitamin $D$ intake were below the proposed recommendations (Table 1).

While no statistically significant difference of metabolic, hormonal and bone parameters was observed 
Table 2 Metabolic, hormonal and biochemical parameters of the metabolism bone and mineral of the population study, according BMD

\begin{tabular}{|c|c|c|c|}
\hline & $\begin{array}{l}\text { HEND } \\
\mathbb{N}=40)\end{array}$ & $\begin{array}{l}\text { Healthy controls } \\
(N=40)\end{array}$ & $p$ \\
\hline Glucose (mg/mL) & $94.2(200)$ & $88.4(17.4)$ & 0.17 \\
\hline Uric acid (mg/dL) & $48(14)$ & $45(1.1)$ & 0.40 \\
\hline Cholesterol tota (mg/dt) & $1920(453)$ & $2055(38.6)$ & 0.16 \\
\hline LDLCholesterol (mg/dL) & $1140(32.4)$ & $124.0(33.2)$ & 0.18 \\
\hline HDC Cholesterol (mg/d) & $584(132)$ & $60.9(9.5)$ & 033 \\
\hline VLDL-Cholester (mg/dL) & $223(13)$ & $21.8(10.3)$ & 086 \\
\hline Triglyceride $(\mathrm{mg} / \mathrm{dL}$ ) & $111.9(57.6)$ & $1099(51.3)$ & 0.82 \\
\hline Leptin (ng/mL) & $0.4(02)$ & $0.4(0.2)$ & 0.78 \\
\hline $\mathrm{KGF}-1$ (ng/mL) & $115.7(53.1)$ & $1345(56.6)$ & 0.13 \\
\hline Total testosterone (ng/dL) & $22.8(9.9)$ & $269(16.6)$ & 059 \\
\hline Prolactin (ng/mL) & $133(156)$ & $80(46)$ & 0.14 \\
\hline FSH (mUK'mL) & $55.7(50.9)$ & $72.6(51.5)$ & 0.15 \\
\hline $\mathrm{LH}(\mathrm{mLV} / \mathrm{mL})$ & $182(2.9)$ & $20.2(3.2)$ & 009 \\
\hline Serum alkaline phosphat ase (U/) & $1089(57)$ & $1133(74.2)$ & 0.77 \\
\hline Serum total cakium (mg/du) & $92(0.4)$ & $93(0.4)$ & 0.06 \\
\hline Serum ionic cakium (mmol $/$ ) & $12(0.1)$ & $12(0.1)$ & 066 \\
\hline Serum magnesium (mg/dt) & $20102)$ & $20(0.2)$ & 0.84 \\
\hline Serum phosphorus img/dL) & $35(05)$ & $36(0.5)$ & 0.49 \\
\hline Serum CTX (ng/mL) & $0.16(02)$ & $0.24(0.3)^{\circ}$ & 0.04 \\
\hline Serum Vitamin D (ng'mL) & $330115 n$ & $299(9.5)$ & 028 \\
\hline Serum PTH intact $(\mathrm{pg} / \mathrm{mL})$ & $315(: 49)$ & $31 \in(15.4)$ & $0.9 ?$ \\
\hline Urinary sodium (mEd/24h) & $1408(682)$ & $157.0(58.9)$ & 050 \\
\hline Urinary phosphorus (mg/24h) & $381.7(347.1)$ & $432.4(368.2)$ & 056 \\
\hline Uninary calcium (mg/24h) & $110.1(84.7)$ & $109.4(103.4)$ & 0.98 \\
\hline
\end{tabular}

between the groups, the serum concentration of total cholesterol was above the recommended values and more vitamin D insufficiency was found in the control group (Table 2). In this group, only four women (10\%) reported 25-OH-D concentrations lower than $20 \mathrm{ng} / \mathrm{mL}$.

In patients with high BMD, negative correlation was verified between femoral neck BMD and total cholesterol $(\mathrm{r}=-0.30 ; p=0.01)$ and LDL-cholesterol $(\mathrm{r}=$ $-0.39 ; p=0.01$ ). On the other hand, serum IGF-1 correlated positively with lumbar spine BMD $(\mathrm{r}=0.36 ; p=$ 0.02 ). Similar correlation was also observed between 25 OH-D and RSMI ( $r=0.33 ; p=0.04$ ) and leptin and BF ( $r=0.44 ; p=0.004)$. Bone resorption was lower in high BMD women $(p<0.05)$ than in controls (Table 2 ).

In the final multiple linear regression model, IGF-1 was positively correlated with lumbar spine BMD in women with high BMD after adjustments for age, weight, BMI, menopause, smoking, lean mass and fat and total energy of the diet. In contrast, LDL-cholesterol and body fatness associated negatively while RSMI and
Table 3 Final model of multivariable regression using equations to estimate HBMD in women

\begin{tabular}{|c|c|c|c|}
\hline Equations & A & $R^{2}$ & p \\
\hline Spine BMD $=1.305+(0.36)) 1 \mathrm{GF}-1$ & 0361 & 0.108 & 0.022 \\
\hline $\begin{array}{l}\text { Femur } B M D=1.0960 .272 \text { (BFM) } \\
0.396(L D L C)+0337 \text { (RSMI) }\end{array}$ & 0.559 & 0347 & $<0,01$ \\
\hline $\begin{array}{l}\text { Total body BMD }=1.5990 .330(F(1.0 .413(\mathrm{P})- \\
(0.298) \mathrm{PTH}\end{array}$ & 0649 & 0367 & $<0.001$ \\
\hline
\end{tabular}

femoral neck BMD associated positively. Additionally, higher fat intake as well as greater serum phosphorus and IPTH had negative association with total body BMD (Table 3).

\section{Discussion}

Our results show that the prevalence of women with high BMD in the healthy general population is relatively low (2\%) and that the main positive aspects are independently associated with IGF-1 and skeletal lean mass. Conversely, aspects related to fats, such as higher body fatness, increased plasmatic concentration of LDL-cholesterol and fat intake, are associated negatively with the BMD in these individuals.

To our knowledge, this is the first study that has identified the main risk factors and protection associated with high BMD in healthy women from the general population, including the three components of body composition and nutritional aspects, as well as biochemical, mineral and hormonal parameters.

It is important to note that there is still not a clear definition of high BMD by the scientific community. In the most recent (2007) official positions of the International Society for Clinical Densitometry (ISCD) [17], there are no cut-off points ( $\mathrm{T}$ - or $\mathrm{Z}$-score) to classify the patient with high BMD [18]. Some authors use Zscore above 2.5 DP [19] and others consider the absolute value of $\mathrm{BMD}\left(\mathrm{g} / \mathrm{cm}^{2}\right)$ in its largest interquartile range [1]. In this study, a $\mathrm{T}$-score above $+2 \mathrm{SD}$, in the absence of fractures or other osteosclerosing disorders, was chosen for this classification. These values were defined in accordance with the premise that $\mathbf{T}$-score values below - 2 SD are indicative of low BMD and increased risk of fractures [17]. Thus, T-score values above + 2 SD could be used to classify individuals with high BMD.

IGF-1 works in both bone formation and resorption $[20]$ and thus plays a relevant role for the acquisition and maintenance of bone mass. Looking at our data of healthy adult women, there was significant association with high BMD, especially in trabecular bone, explaining 
nearly $11 \%$ of the bone density variation in these individuals. Other authors have found similar results [21-23].

Although there is vast positive evidence of IGF on bone mass, its function should be better explored Recently, Cohen et al. showed osteoblasts seem to be resistant to the IGF-1 effect in women with osteoporosis. Thus, it would not have a positive role and should be evaluated with caution [24]. Furthermore, Clemens \& Karsenty, underscore osteocalcin as a regulator of glucose metabolism by means of insulin receptors present in osteoblasts, acting both on systemic glucose homeostasis and BMD increment [25].

Lean mass is the main component of body composition associated with BMD [26-29], in which mechanical stress [30] and mechanosensory signaling, promoted by osteocytes, are the most studied determinants [31]. These aspects have been partially confirmed by our results since physical activity, per se, was unable to explain high $\mathrm{BMD}$ in healthy women.

Most likely, the women with high BMD evaluated in our study had lower bone resorption rate, as suggested by the lower values of CTX when compared to healthy controls. In view of the negative correlation between this bone turnover marker and the RSMI $(\mathrm{r}=-0.31 ; p=$ 0.05 ), we suggest that the trophic role of muscle mass (pro formation), associated with lower bone resorption, resulted in a positive net effect on BMD. One of the possibilities to explain lower bone resorption in women with high BMD may be lower serum FSH- and LHplasma concentrations $(p=0.09)$, which inherently can play a negative role on bone tissue [32,33].

Alternatively, there are conflicting studies on the role of fat mass on BMD $[34,35]$, since body weight traditionally has a positive role on bone mass, especially with greater cortical and periosteal remodeling [35]. In our case, fat mass, including percentage and absolute values, played a negative role on femoral neck BMD, independent of body weight, hormonal variables (aromatization of estrone to estradiol), and adiposity type (gynecoid vs. android).

The physiopathogenic mechanisms involved with the deleterious role of body fatness on bone tissue are not fully known, but some authors believe that protective bone strength is most associated with dynamic loads, those found with lean and muscular mass, than with static, observed with fat mass [36]. Moreover, the proinflammatory state observed in individuals with obesity or with greater adiposity may be related to increased bone resorption and thus greater injury to bone health, introducing the new concept of lipotoxicity [37].

It is important to emphasize that, according to our data, there was positive correlation between $\mathrm{BF}$ and serum leptin concentrations, suggesting greater peripheral resistance to leptin and therefore to insulin.
Recently, leptin has been pointed out as an important regulator of osteoclast differentiation, since it controls the expression of RANKL (receptor activator of nuclear factor kappa-B ligand) and CART (cocaine and amphetamine regulated transcript) [38].

Worse lipid profile, defined by LDL cholesterol, was another aspect negatively associated with femoral neck BMD in women with high BMD, emphasizing once again the participation of lipid metabolism on bone tissue [35]. Lipoprotein lipid oxidation is able to stimulate osteoclastogenesis [39], as well as the greater intake of fats, via RANKL expression on activated T lymphocytes [40]. Moreover, this oxidation may have a negative action on osteoblast differentiation and bone formation [41]. Recently, some authors have shown greater bone loss [42] and increase in resorption bone markers in patients with hypercholesterolemia [43].

Although the incidence of dyslipidemia in patients with osteoporosis is still not known, the atherogenic lipid profile is known to be significantly associated with lower bone density in postmenopausal women [44] However, the use of statins does not seem to play a beneficial role on bone health [45].

Likewise, the daily intake of lipids was also a factor negatively associated with $\mathrm{BMD}$, as previously reported by other authors [46]. The ingestion of large amounts of fat can negatively affect the absorption of calcium, prostaglandin synthesis and osteoclastogenesis. It also increases the oxidation of lipids [47]. In addition, the ingestion of large amounts of fat is related to the increased expression of adipocyte differentiation factors, in particular to PPAR- $\gamma$ (peroxisome proliferator-activated receptor gamma) [48]. According to data from the Framingham Osteoporosis Study, high fat consumption can be harmful to bone mass, particularly in individuals with greater allelic variation in PPAR- $\gamma$ [48]. In our study, no gene polymorphisms were evaluated. It is worth mentioning that the exclusion of obese women reinforces our findings, since, in all likelihood, they consumed even more fat. Thus, lipid consumption above DRI recommendations is able to negatively affect BMD.

Traditionally, higher concentrations of $\mathrm{iPTH}$ and phosphorus are associated with worse bone health, as observed in patients with chronic renal insufficiency. Our results show that this combination is associated negatively with BMD in patients with high BMD.

Surprisingly, no significant difference was observed in mean plasma concentrations of vitamin $\mathrm{D}$ between the groups. Accordingly, women had high BMD independent of vitamin $D$, while on the other hand there was positive interaction between vitamin $D$, lean mass and higher femoral neck BMD. The role of vitamin D receptor (VDR) in muscle cells [49] could explain these findings. Unfortunately, falls, muscle strength and physical 
incapacity were not objectives of this study and further research is needed to better understand the interaction between these aspects.

Additionally, women with high BMD had higher intake of protein and phosphorus, after adjustments for energy. However, when adjusted for protein intake, there was no significant difference in the daily intake of phosphorus (1144.1 \pm 140.3 vs. $1103.6 \pm 123.8 \mathrm{mg}, p=$ 0.17 ) between the high BMD and control groups, respectively. Several epidemiological observations on protein intake confirm our results [50], although some have shown a negative role [51]. When observing the beneficial role of protein intake, it is important to note that the effect of the protein-induced acid load does not promote bone loss or urinary calcium [52]. In addition, protein intake is able to increase IGF-1 values by almost $30 \%$ [53] and thus provide beneficial effect on bone metabolism. The combination of these two latter aspects was observed in our study.

Conversely, when evaluating protein intake (g) adjusted for body weight $(\mathrm{g} / \mathrm{kg})$, there was no significant difference between groups $(1.2 \mathrm{~g} / \mathrm{kg}$ for high BMD vs. $1.1 \mathrm{~g} / \mathrm{kg}$ in controls, $p=0.2$ ), although both were above the recommendation for healthy individuals $(0.8 \mathrm{~g} / \mathrm{kg})$.

The limitations of this study include the lack of evaluation of genetic markers, the lack of measurement of muscle strength and variables that quantify the state of oxidative stress, as well as the amount of fluoride in water or in food ingested and the type and the quantification of visceral fat.

The strengths of this study included the careful selection of the sampling procedures, excluding the risk factors traditionally associated with high BMD such as black ethnicity, obese individuals, athletes and patients infected by hepatitis $\mathrm{C}$ virus $(\mathrm{HCV})$ or with degenerative alterations of the lumbar spine or hip. Moreover, results were strengthened with the inclusion of a control group matched for age, weight, fat mass, ethnicity, physical activity and smoking, which reduces various biases and confounding factors.

This study expands upon the scientific understanding of bone and mineral metabolism, since it includes new aspects of practical interest, such as body adiposity, lipid profile and fat intake, and the non-pharmacological handling of patients with bone fragility. Thus, beyond adapting the intake of calcium and vitamin D and stimulating resistance exercises for an individual with osteoporosis, the physician and nutritionist should also guide the lower intake of fats, encourage aerobic activities and improve the lipid profile of these individuals.

\section{Conclusion}

Thus, our results show that the main protection factors associated with high BMD in healthy women are IGF-1 plasmatic concentration, skeletal lean mass and intake of protein. On the other hand, body fatness, worse lipid profile and fat intake played a negative role.

\section{Methods}

Study design, sampling and patient selection

After reviewing the database of approximately 21,500 BMD scans performed in healthy women for any reason. from June 2005 to October 2010, were found 421 exams (1.96\%) with high BMD. This information has been originated from the São Paulo metropolitan area, Brazil, including primary, secondary and tertiary hospitals as well as data from general practitioners.

Through convenience sampling and consecutively, exams with BMD values above $1400 \mathrm{~g} / \mathrm{cm}^{2}$ or $\mathrm{T}$-score greater than +2 SD at lumbar spine and/or above $1200 \mathrm{~g} / \mathrm{cm}^{2}$ or $\mathrm{T}$-score greater than $+2 \mathrm{SD}$ at femoral neck were eligible to this study. Furthermore, none of these sites could have osteopenia or osteoporosis [2] or previous fracture.

The control group included healthy women matched for age, weight and ethnicity. Besides, they had BMD values lower than $1400 \mathrm{~g} / \mathrm{cm}^{2}$ (T-score less than 1.99 DP) at lumbar spine and $/ o r$ under $1200 \mathrm{~g} / \mathrm{cm}^{2}$ (T-score less than 1.99 DP) at femoral neck. Similarly, none of the sites could have osteopenia or osteoporosis [2]

Women aged below 30 and above 65 years, black people, pregnant and those with BMI higher than $29.9 \mathrm{~kg}$ $\mathrm{m}^{2}$ were excluded. Moreover, the presence of diseases associated with any nutritional imbalance or osteometabolic conditions, including renal, infectious, neoplastic, digestive, endocrinologic, rheumatic and cardiovascular diseases were not included. History of alcoholic consumption [54], dyslipidemia, chronic hepatitis C, hormone treatment and individuals using statins or thiazide diuretics also were not eligible for the study.

Of 421 women, 381 (90.5\%) were excluded for not meeting the eligibility criteria, particularly obesity and black ethnicity. Thus, 40 (9.5\%) women constituted the study group.

The study protocol was examined and approved by the Research Ethics Committee of the University of São Paulo (USP) (number: 0170/09) and Universidade Federal de São Paulo (Unifesp/EPM) (number: 0229/04) and the participants who agreed to participate in the study gave written informed consent.

\section{Collection of clinical information}

Standardized questionnaires were used to verify the demographic characteristics and medical history. Menopause was defined as more than 12 months since the last menstrual period [55].

\section{Evaluation of food intake}

Food intake was measured through a Food Frequency Questionnaire (FFQ), consisting of 62 food items and 
validated in Brazil [56]. The FFQ was administered by a trained nutritionist and the information provided reflected the pattern of food intake for the last six months. Portion size was evaluated with the aid of a food portion photo set.

Dietsys software, version 4.0 (National Cancer Institute, Bethesda, MD), was used to calculate the daily nutritional intake of total energy ( $\mathrm{kcal} /$ day), macronutrients and some micronutrients, including calcium, phosphorus and vitamin D. All nutrients were adjusted for energy. Phosphorus was also adjusted to protein intake according to the method proposed by Willett \& Stampfer [57] and compared with the Dietary Reference Intakes (DRIs) recommendation from Food and Nutrition Board [14-16].

\section{Evaluation of physical activity}

Physical activity (PA) was assessed through the Baecke Questionnaire of Habitual Physical Activity [58]. This tool evaluates three PA's main components: work, sport and leisure. All the answers, with the exception of the occupation activity and the type of sport, were precoded on a scale of 5 points, with descriptors that range from never (1) to very often (5). The level of occupational activity was classified as low (1), medium (3) or high (5). The score of sport activities was calculated by the equation: [intensity code $\times$ duration code $\times$ year proportion code] $\times 1.25$. If there was more than one sport practiced, the values were added. As a result, each component of PA can receive a maximum of five points, with a maximum score of 15 . Each index was rounded to the nearest tenth of the unit or point.

\section{Anthropometry}

All individuals were measured and weighed on a standard balance beam scale (Filizola ${ }^{*}$ ), calibrated periodically, wearing light clothes and without shoes. Weight was measured to the nearest $100 \mathrm{~g}$. Standing height was measured with the aid of a stadiometer (Filizola ${ }^{*}$ ) by a trained individual. Body mass index (BMI) was calculated by the ratio between weight $(\mathrm{kg})$ and height, in meters squared $\left(\mathrm{kg} / \mathrm{m}^{2}\right)$

\section{Assessment of body composition and bone mineral density measurements}

BMD assessment was performed on the lumbar spine (L1L4) and femoral neck $\left(\mathrm{g} / \mathrm{cm}^{2}\right)$ by using dual energy X-ray absorptiometry (DXA), DPX MD + densitometer (GELunar Radiation Corporation, Madison, WI, USA). A welltrained technician followed a standard protocol. Quality control was done daily and phantom cross-calibration three times per week. For premenopausal women, Z-score was used in compliance with International Society of Clinical Densitometry (ISCD) recommendations [21] and supported by the Brazilian Society of Clinical Densitometry (SBDens), a national regulatory agency [59].

Body composition was also measured by DXA. Total body fat mass was evaluated in absolute values as body fat $(\mathrm{kg})$ and percentage (BF\%). Lean mass was defined as fat free mass (FFM), with special emphasis to appendicular lean mass (ALM) and the relative skeletal muscle index (RSMI). For women aged over 50 years, sarcopenia was defined according to the classification of Baumgartner [60], in which RSMI values below two standard deviations relative to young healthy population or less than $5.45 \mathrm{~kg} / \mathrm{m}^{2}$, for women; indicative of that condition. For younger women, the criterion was not used RSMI is the ratio of appendicular lean mass $(\mathrm{kg})$ and height squared $\left(\mathrm{m}^{2}\right)$.

The coefficient of variation was $1.5 \%$ for the lumbar spine and total body and $2 \%$ for the femoral neck.

\section{Radiographic evaluation}

Radiographic evaluation of dorsal and lumbar spine in anteroposterior and lateral positions was performed by a rheumatologist blinded for clinical data and specific pro cedures of the protocol data in order to exclude vertebral degenerative processes, as well as other causes of high BMD, including bone metastases, Paget's disease, fracture or congenital deformities (Schmorl's nodes, severe scoliosis). The image acquisition protocol followed the recommendation of $120 \mathrm{~cm}$ for tube film distance and X-ray beams centered in T8 and $\mathrm{L} 3$, respectively.

\section{Laboratory and biochemical analysis}

All the blood samples were collected in the morning after twelve hours of fasting.

Metabolic and hormonal parameters included glucose and uric acid, both evaluated by calorimetry; total cholesterol, fractions and triglycerides by the Trinder method; insulin growth factor-1 (IGF-1) by chemiluminescence, leptin by ELISA (IBL International) and tota testosterone by RIA. Prolactin, follicle-stimulating hormone (FSH) and luteinizing hormone ( $\mathrm{LH})$ were measured by fluorometric method.

Bone and mineral metabolism were also measured. Bone formation was evaluated by alkaline phosphatase (ALP) activity through enzymatic-kinetic method. Bone resorption was assessed by serum C-terminal fragment of type-1 collagen (CTX), through chemiluminescence. Serum total calcium, ionized calcium and magnesium were measured by colorimetric assay and serum phosphorus by UV mobility. Intact parathyroid hormone (iPTH) and 25-hydroxivitamin D (25-OH-D) were evaluated by electrochemiluminescence. Additionally, 24-hour urine was collected for measuring urinary calcium by colorimetric assay, as well as the fraction of sodium excretion (potentiometry) and phosphorus (UV mobility). 
The classification of vitamin D sufficiency adopted was proposed by Dawson-Hughes [61].

\section{Statistical analysis}

The results were analyzed as mean $\pm \mathrm{SD}$. The Kolmogorov-Smirnov test was used to verify the normal distribution of variables. Data with non-normal distribution were transformed into logarithm. Mean differences between groups were assessed by Student's t-test. Categorical variables were analyzed by chi-square test of association. The correlation between variables was evaluated by parametric tests and Pearson correlation.

Multiple linear regression models were used to identify factors associated with high BMD, used as dependent variable. Clinical characteristics, food intake data, physical activity score, body composition measurements and concentrations of biochemical parameters were considered as independent. P-values of $<0.05$ were considered significant. All analyses were performed with the aid of Statistical Package for the Social Sciences, version 16.5 for Windows (SPSS Inc., Chicago, IL).

\section{Adknowledgements}

The authors thani the fundagho insivito de Diagnostico por imagem of $\mathbf{C}$ i) for support in the recruirment of patients and concucting bore densitometry exams of the lumbar spine and femoral neck utich we essertial for this study, and ako the Certral Laboratory of UNFESP/LPM for support in the laboracory analysis of hematological biochemical serologic mineral and hormonal profiles. The authors ako tharik the Numrition Department of the faculy of Fublc tiealth in respect to the implement ation of laborarory tess for CTX, vitamin C, KGF-1 and IFTH

\section{Author detaik}

Nutrition Department School of Fublic Health. Sao Paulo Universiry. Av. D Amaldo, 715, Salo Faulo SP, BrazI CEP -0:246904 "Nutrition Department school of Public Health. Sao Paulo Universtry. Av. Dr. Amaldo. 715, Sto Paulo - SP, Brazil CEF -01246994. "Rheumatology Division, Universicace feceral de Sá PaulorEscola Paulista de Mecicina Nrifesp. LPM. Av Dr Atro Arantes 669. apto 105, Vha Clerrentina S\$o Paulo-SP, Brazil CEF O4042-033 "Rheumatology Dvision. Universicade Federal of SaO Paulorkscola Pauista de Medicina Nnifesp/EPM, Rua Pedro de Tdeso 650.2 Andar-Vla Clemertino, CFP 04039.002 S\$O Paula SF, Brasil, Disciplina de Feumarobcis

\section{Authors' contributions}

KSS performed the sample collection, nutritional assessments and processed the data as well as conducted statistical analysis and drafted the manuscript. VIS and LAM participated in the design of the study and heiped in analyaing data and in drafting the manuscript. MMP participared in the design of the stucy, performed medical appointment and BMD measurements and anatyzed all spine $X$-ray exams. Additionally, he helped in data interpretation and in drafting of the manuscript. All authors have read and apporoved the frinal version.

\section{Competing interests}

No dicclosutes. There is no affliation, financlai agreement or any othe involvement with any company.

\section{Received: 27 December 2011 Accepted: 12 March 2012} Publishect 12 March 2012

References

1. Pesonem \&, Sircla i, Tuppurainen M. Livelin \&. A.hara E, Honkaken R Koóguee H: High bone mineral density among perimenopausal women. Csteopoosis ht 2005, 16:1899-1906.
World Heatr Organizaricn W. Assessment of fracture risk and its application to screening for postmenopausal osteoporosis Repon of a mio Seudy Group. Word theath Organ Jech Ree Seer 1994, 8431-129

3. Onwol ES, Bevan L, Phipos KR. Determinants of bone mineral density in older men. Csteoporas int 2000, 11:815-821.

4. Bel Nit Bone and mineral metabolism in African Americans. Inends Endochno' Merat 1997.8240 .245 .

5. Van Wesenbeeck L, Cleiren E, Gram \& Beak RX. Benichou O. Scopeliti D. Key L. Renton T, Ranels C Gong Y., Warman ML, De Vernejoul MC.

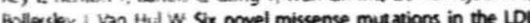
receptor-nelated protein 5 (LRPS) gene in different conditions with an increased bone density. Am i Hium Gene $2003,72.763-771$.

6 Lod SR Warc A. Willams P. Dranovik E. The effects of a community exercise program on fracture isk factors in older women. Ossecporos in $1996,661-367$

? Heaner RP, Rerler RR Stegman MR Moy A. Calcium absorption in women relationships to calcium intake, estrogen status, and age. $J$ Bon Mine Re 1989, 4.469 .475 .

8 Oin $X$ Wang S, Yu M. Zhang L, Li X Zuo $Z$, Thang $X$, Wang L:Child Skeletal Fluorosis from Indoor Burning of Coal in Southwestern China. fnvron Pible ite d'th 2009 200(9) 969764

9. Pasco JA, kotowica MK, Henry MU, Sanders KM Nichoison $K C$, Geeilong Ostecpassis Srudy Statin use, bone mineral density, and fracture risik Geelong Osteoporosis Study. Arch inten Med 2000, 162537-540

10. Kamel HK. Low-dose thiazide and bone density. Am intem Med 2002. $13625: 253$

11. Cacley iA LiCas FL. Kullet Hit, Vogt Mn, Browner WS. Cummings SR. Bone mineral density and risk of breast cancer in older women the study of osteoporotic fractures. Study of Osteoporotic Fraqures Research Group. AMM 1906 276:1404 1408.

12. Whyte MP. Mils BG. Reinue WR, Podgomik MN Foodman GD, Gannon Fit Edoy MC, MCAlistet WHt Espnasile skeletal hyperphosphatasia: a new familial metabolic bone disease. $;$ Bone Mine Bes 2000, 15.2330.344

13. Truschnigg B. Chong C Habemayerova L Karelis AD, Komorowski t Female boxers have high bone mineral density despide low fat mass. high energy expenditure, and high inidence of oligomenorrhes. Axpl chiso Nut serat $200533563-960$

14. Food and Nurtition Bcard insitute of Medicine Dietary Reference intakes for Energy. Carbohydrate Fiber, Fat, Fatty Acids. Cholesterol, Protein and Amino Acids (Macronutrientsi. Washington $\mathcal{X}$ : National Kcademy Press: 2005 .

15. Food anc Nurition Bcarc, Insitute of Medicine Dlecary Reference intakes for calcium, phosphons, magnesium, vitamin $\mathrm{D}$ and fluonde. Warhingron DC- National Acaceny Pres: 1997.

15. Food and Nuttion Borce insiture of Medicine Diecary Reference intakes for Viramin C Vitamin E, Selenium and Carotenoick. Washington $D C$. Narional Acacemv. Press: $x 000$

17. Intemational Society for Clinical Densitometry Official Positions. (ntrp $/$ t

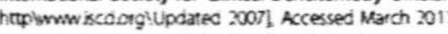

18. Simonelli C Ader Ph, Blake GMC Caudil IP, Whan A, Leb E, Mrici M. Prica $C$. Fis SP. Rosen C. Kendler Dt: Duatenergy $x$-ray absorptiometry technical is sues: the 2007 ISCD official Positions. I Cin Derrtom 2006, $11: 109.122$

19. Morgan SL. Peace F, Lopez-Ben R, Fineberg N Distribution of Z-scores in University cohon with an emphasis on high" bone mineral density. In Dension 2010, 13:385-391.

20. Hil PA. Reynolds $\nu$, Mellie MC: Osteoblasts mediate insulin-like growt factort and $+1 /$ stimulation of osteoclast formation and function indoceno'ingy 1905, 136:124131.

21. Barret-Connor $E$, Goocman-Gruen D: Gender differences in insulinlike growth factor and bone mineral density association in old age the Rancho Bernardo Study. I Bone Miner Res 1998, 13:1343-1349

22. Boonen S. L esaffie E, Dequeter i Aerssens 1 , Nijs , Pelemans W, Boullon $R$. Relationship between baseline insulin-like growth factor-1 (GF-1) and femoral bone density in women aged over 70 years: potential implications for the prevention of age-related bone loss. $j$ Am Gentar so: 1996.441301 .1306

23. Janssen JA Burget H. Stolk $P$. Grobbee DE de jong FH, Lamberts SW Fols $H$ th: Gender-specific relationship between serum free and totaliGf-1 and bone mineral density in elderly men and women. fur is indocrind 1995138627.632 
24 Cohen A Demoster DW, Recker Pr. Sten EM Lapoe MA, Zhou $H$, Wrth $A$. van Lenthe Sitt, Kohler T, Zwahlen A Muller R, Rosen U, Cemers 's

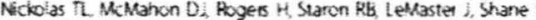
Abnormal Bone Microarchitedure and Evidence of Osteoblast Dysfunction in Premenopausal Women with idiopathic Osteoporosis. JEA Endocand Merob $2011,963095-3101$.

25. Ciemens $\pi$. karsenty $\&$ The osteoblast an insulin target cell controlling glucose homeostasis. 3 Bone Mine: Pes 2011, 26.677 680.

26. huzwial CR, Amancic OM Vralie MS, Szejnfeic U. Priheiro Mre. Effect of cakcium intake, tennis playing and body composition on bone-mineral density of Brazilian male adolescents ht ispont Nur ixez kterab 2006. 18524538

27. Penteado VS, Casro CH Pinneiro Mose M. Santana M, berodino Is de Mello $M$; , Szenteld $\mathrm{C}$ : Dret body composition, and bone mass in welltrained cyclists. I Cin Densiom 2010 13:43.50.

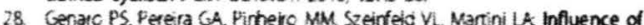
body composition on bone mass in postmenopausal osteoporotic women. Arch Geronto' Geniar 2010. 51:295.298

20. Pedreir PCL. Finheiro MM, Szejnfeld $\mathrm{U}$ : Bone mineral density and body composition in postmenopausal women with psorlas is and psoriatic anthritis. Arthritis hes ther 2011, 13R:6

30. Iikh -imst 1, Brownbill PA. Ludemann MA Fu R Gritical factors for bone heath in women across age span: how important is musde mass? Mets axe Womens Heath 2002 72

31. Bonewald Lf: The amazing osteocyte. $j$ bone Miner fer $2011,26: 22938$

32. Pertien DS. Achentach S., Biecsoe SE, Walse B. Suva U. Khosla S, Gaody D. Bone turnover across the menopause tran sition: correlations with inhibins and folliclestimulating hormone i (in Endocrina theab $200 \mathrm{H}$ $91: 16601670$

33. Xu ZF, Wang AF, Wu XP, Zhang $H$, sheng $2 F$, Wu $X Y$, Xie H, luo XH, libo IX: Relationship of age-related concentrations of serum FSH and $\mathrm{LH}$ with bone mineral density, prevalence of osteoporosis in native Chinese women Cin Chim ACE 2009, $4005: 13$

34. Peic $\mathbb{R}$ Piank $L D$. Evans $M$ : $F$ at mass is an imponant determinant of whole body bone density in premenopausal women but not in men. Cin indocring Mesob :992, 75:777782.

35. Hsu Y, Venners S Terwedow H, feng *, NSu I, U Z Lard N, Brain 0. Cummings SR, Bowrein MA, Rosen C1, Xu X. Relation of body composition fat mass, and serum lipids to osteoporotic fractures and bone mineral density in Chinese men and women. Am, $\mathrm{Cin}$ Nuty $20 \mathrm{OS}$ 83:146. 154

36. L.L WW. Tarbor S. OConnox U, walke PS: Influence of muscle activity on the forces in the femur. an in vivo study. : 15 merh 1997.30101-1106

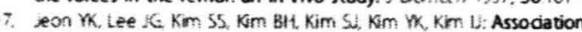
between bone mineral density and metabolic syndrome in pre and postmenopausal women. indoc / $2011,58.87 .93$.

38. karsenty $C$ C Convergence between bone and energy homeostas es: leptin regulation of bone mass. Cell Merob 2006 4 341.348

39. Graham LS Parhami F, Tintut Y, Kachen CM, Demer LL, Effres PHA Oxidized lipids enhance RANKL production by $T$ hymphocyes implications for lipid-induced bone loss. Cin mmunol 2009 , 133.265-75.

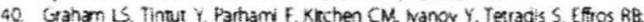
Bone density and hyperlipidemia the T-tymphocyte connection. I Bone Mine Fes $2010,25 \cdot 24602469$

41. Parhami F, Mocy N, Gnaravi $N$ Baliaro As, Tintut Y, Demer LL: Role of the cholesterol biosynthetic pathway in osteobla stic differentiation of marrow stromal cells.; bone Mine Res $2002,17: 1997-2003$.

42. Taraida $A$ lino $K$. Abe K Taniguchi R. Higuchi T, Meunuma $H_{3}$ Nakaī S: Hypercholesterolemia accelerates bone loss in postmenopausal women Umacaer 2011, 14.105.111.

43. Maima I, Shimatsu $A$ Kamarse $Y$, Satoh $N$, fuka h Ninomya $K$ Marsumua 1 , Atac $K$ increased bone tumover in patients with hypercholesterolemia. Indod ; 2008 , 55:143.5100

44. Oeazc P. Atherogenic lipid profile and elevated lipoprotein (a) are assocated with lower bone mineral density in early postmenopausa overweight women. fur I ípidemiol 2004, 19:1105.1112

45. Yue 2 Thang $X$ Long $B$ Yang $M$ : Statins and bone heath in postmenopausal womer: a systematic review of randomized controlled triak Menapouse $2010.17: 107$ i-1070

46. Macooniald HM New SA Golden MHIN Campbell MK. Feid DM Nutritional assodations with bone loss during the menopausal transition: evidence of a beneficial effect of calcium, alcohol, and fruit and vegetable nutrients and of a detrimental effect of farty acids Am I G in Nint 2004 79:155-165.

47. Parhami F: Possible role of oxidized lipids in osteoporosis thyperlipidemia be a risk factor? Poustagiandins Levkor issenr fary Aods 2003, 68:373-378.

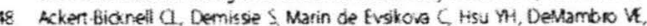

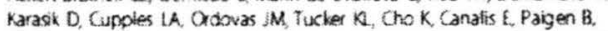

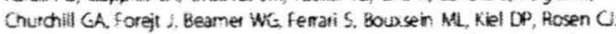
PPARG by dietary fat interaction influences bone mass in mice and humans. $;$ Bone Mine fee 2008, 23.1396-1406

49. Windelincks $A$, De Mars $G$ Beunen $G$, perssens : Delecluse $C$, lefene 2. Thomis $M A$. Polymorphisms in the vitamin D receptor gene are associated with musde strength in men and women. Ccteopors in 2007, 18:1235-1242

5. Promislow it Gocdman-Gruen D. Stymen D. Barrett-Connot E. Protein consumption and bone mineral density in the elderly, the Rancho Bernardo Study. Am if ipidemid 2002, 155.636-644.

51. Selimever $D$, Stone $K$. Stastian A Cummings SR: A high ratio of dietary animal to vegetable protein increases the rate of bone loss and the risk of fracture in postmenopausal women. Study of Osteoporotic Fractures Research Group. Am j Cin Nurt 2001, 73.118:122.

52. Fenton TR, I yon AW, fliasziw $M$ Tough $S C$, Hanley DA: Metaanalysis of the eflect of the acid-ash hypothesis of osteopor osis on calcium balance. Bone Mines Res $2009,241835.1840$

53. Hunt $R$, cohnson $L K$ farbs Poughead $X X$ : Detary protein and calcium interact to influence calcium retention: a controlled feeding study. $A m$, CIn Nirr 2009.89.1357-1355.

54. Dawson Dh, Grant BF. LI TK: Quantifying the risks associated with exceeding recommended drinking limits. Aicohvic in tap kes 200 29:902-908.

55. Butier 1 . Santoro $N$. The reproductive endocrinology of the menopausal tran sition. Steroids $2011,76.627$. 035.

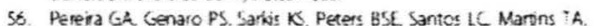
Marini $L$ : Validaça do questionário de frequéncia alimentar para mulheres com osteoporose. Marre: 2005,3025

57. Wilier $W$. Stampfer $M$ Implications of total energy intake for epidemiological analyses. In Mupraon exdemiobgy. 2 eciron. fored by:

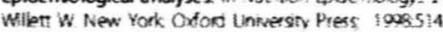

58. Breck ih jurema. Frigters. E. A short questionnaire for the measurement of habitual activity in epidemiological studies Am J C in Nari 198:. 36:936-942.

59 Brandis CMA Gamaros BX Zerbini CA. Plamler PG, Mendonça IM

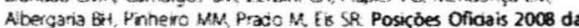
Sociedade Brasileira de Densitometria Clinica (SBDens). Aro BrCs Endadinai Herobai 2009, 53:107-1:2

60. Baumgarnes RN, Stauber PM. Koehier KM, Rometo L Garry P A Associations of fat and muscle masses with bone mineral in elderty men and women. Am J Cin Nurr $7996,63365-372$

61. Damson tughes $B$. Heaner AP. Holick MF, Lips $P$, Meunier $P$; Vieth $R$ Estimates of optimal vitamin status. Ostesporosis in: 2005, 16.713-716

doi: $10.1186 / 1476-511 \times-11-37$

Cite this article as: Sarkis er oi: Low fatness, reduced fat intake and adequate plasmatic concentrations of $L D L$-cholesterol are associated with high bone mineral density in womers a cross-sectional study with control group lipids in Heath ond Diseose 201211.37. 
Artigo 3:

"The relationship between dietary patterns and high bone mineral density"

Artigo original à ser submetido 
The Relationship Between Dietary Pattern and High Bone Mineral Density

Karin S Sarkis ' ${ }^{1}$, Marcelo M Pinheiro ${ }^{2}$, Vera L Szejnfeld ${ }^{3}$, Lígia A Martini ${ }^{4}$

${ }^{1} \mathrm{MsC}$, Nutrition Department, School of Public Health, Sao Paulo University

Av. Dr. Arnaldo, 715 - São Paulo - SP - Brasil - CEP - 01246-904 - e-mail: ksarkis@usp.br

${ }^{2} \mathrm{MD}, \mathrm{PhD}$, Rheumatology Division, Universidade Federal de São Paulo/ Escola Paulista de Medicina (Unifesp/ EPM)

Rua Pedro de Toledo, 650 - $2^{\circ}$ Andar - Vila Clementino - CEP 04039-002 - São Paulo - SP - Brasil - Disciplina de Reumatologia e-mail:mpinheiro@uol.com.br

${ }^{3}$ Professor, MD, PhD, Rheumatology Division, Universidade Federal de São Paulo/ Escola Paulista de Medicina (Unifesp/ EPM)

Av Dr Altino Arantes, 669, apto 105, Vila Clementino - São Paulo-SP - Brasil - CEP 04042-033 -

e-mail:vera@cura.com.br

${ }^{4}$ Professor, PhD, Nutrition Department, School of Public Health, Sao Paulo University

Av. Dr. Arnaldo, 715 - São Paulo - SP - Brasil - CEP - 01246-904 - e-mail: lmartini@usp.br

Address correspondence and reprint requests to:

Lígia Araújo Martini, Av. Dr. Arnaldo, 715 - São Paulo - SP - Brasil - CEP 01246-904 - e-mail: 1martini@usp.br 


\section{Abstract}

Background: Several parameters are associated with high bone mineral density (BMD), among them the diet. The objective of the present study was to identify the differences between dietary pattern in women with normal and high BMD. Methods: After reviewing the database of approximately $21500 \mathrm{BMD}$ scans performed in the metropolitan area of São Paulo, Brazil, from June 2005 to October 2010, high BMD (over $1400 \mathrm{~g} / \mathrm{cm}^{2}$ at lumbar spine and/or above $1200 \mathrm{~g} / \mathrm{cm}^{2}$ at femoral neck) was found in 421 exams. Exclusion criteria were age below 30 or above 60 years, afrodescendets, pregnant or obese women, disease and/or medications known to interfere with bone metabolism. A total of 40 women with high BMD were included and matched with 40 women with normal BMD, paired to weight, age, skin color and menopausal status. Medical history, diet and physical activity were assessed through validated questionnaires. Foods were systematically grouped together on the basis of similarities of food and nutrient composition and entered into factor analysis. Body composition was evaluated through a GE-Lunar DPX MD. Radiography of the thoracic and lumbar spine was carried out to exclude degenerative alterations or fractures. Statistical analysis included parametric tests and factor analysis. $\mathrm{P}<0.05$ was considered significant. Results: The mean age was 50.9 (8.3) years. There was no significant difference between groups in relation to age, weight, BMI, smoking, fat mass and menopausal status. Five components were identified through factor analysis that explained approximately $75 \%$ of the variability within the sample. The HBMD group had a healthier diet. Cereals, tubercles, beans, dairy products, fruit, vegetables, sweets, meats and eggs, with low of processed meat, explained more than $50 \%$ of the total variance. On the other in control group, diet was constituted with a 
processed meat, food rich in fat and low alcoholic beverages, which differ the other group. Conclusion: Our results demonstrate the differences between dietary patterns in two different groups according to BMD. The HBMD group had a healthier, balanced dietary

Keywords: bone mineral density, body composition, dietary pattern, diet, women 


\section{Introduction}

In recent years, the occurrence of high Bone Mineral Density (BMD) has been observed in some individuals [1] and it is related to anthropometric data (overweight and obesity) [2], demographics (african descendants), gender (males) [3], as well as genetic factors (LRP5 mutations) [4]. Some medications such as statins [5] and thiazide diuretics [6] may also have a protective effect. In addition, patients with breast and endometrial cancer [7], type II diabetes mellitus [8] and

athletes have higher BMD than healthy individuals [9]. Apart from these, diets is an important factor since it has been observed that a calcium intake (above 1500 $\mathrm{mg} /$ day) and food or water with excess fluoride [10,11].

Diet is one of the important modifiable factors for the development and maintenance of bone mass, however, the most common approach, examines single nutrients or foods, may not adequately account for complicated interactions and cumulative effects. Because people consume diets consisting of a variety of foods with complex combinations of nutrients, rather than isolated nutrients, the examination of only single nutrients or foods could result in the identification of erroneous associations between dietary factors and disease [12].

The dietary patterns allow investigators to examine the whole diet. It may better account for the cumulative and interactive effects of foods and nutrients within the diet and is proposed to better reflect real-world dietary intake in relation to biomarker of disease. [13-15]. There are some studies about dietary pattern and BMD [12, 16-18], but anyone compared the dietary pattern in women with High $\mathrm{BMD}$ and health control with normal BMD, this results can help to optimize the management of patients with osteoporosis using a modifiable factor, the diet.

In this regard the objective of this study was to identify the differences between dietary pattern, according to BMD with high BMD in healthy women, through cross-sectional study with control group.

\section{Methods}




\section{Study design, sampling and patient selection}

After reviewing the database of approximately 21500 BMD scans performed in healthy women for any reason, from June 2005 to October 2010, 421 exams $(1.96 \%)$ with high BMD were found. This information has been originated from the São Paulo metropolitan area, Brazil, including primary, secondary and tertiary hospitals as well as data from general practitioners.

Through convenience sampling and consecutively, exams with BMD values above $1400 \mathrm{~g} / \mathrm{cm}^{2}$ or T-score greater than $+2 \mathrm{SD}$ at lumbar spine and/or above 1200 $\mathrm{g} / \mathrm{cm}^{2}$ or T-score greater than $+2 \mathrm{SD}$ at femoral neck were eligible.

The control group included healthy women matched for age, weight and ethnicity. Besides, they had BMD values lower than $1400 \mathrm{~g} / \mathrm{cm}^{2}$ (T-score less than $1.99 \mathrm{DP}$ ) at lumbar spine and/or under $1200 \mathrm{~g} / \mathrm{cm}^{2}$ (T-score less than $1.99 \mathrm{DP}$ ) at femoral neck. Similarly, none of the sites could have osteopenia or osteoporosis [19].

Women aged below 30 and above 65 years, African descendants woman, pregnant and those with BMI higher than $29.9 \mathrm{~kg} / \mathrm{m}^{2}$ were excluded. Moreover, the presence of diseases associated with any nutritional imbalance or osteometabolic conditions, including renal, inflammation, neoplastic, digestive, endocrinologic, rheumatic and cardiovascular diseases were not included. History of alcohol consumption [20], dyslipidemia, chronic hepatitis C, hormone treatment and individuals using statins or thiazide diuretics also were not eligible for the study.

Of 421 women, $381(90.5 \%)$ were excluded for not meeting the eligibility criteria, particularly obesity and african descendants. Thus, 40 (9.5\%) women constituted the study group.

The study protocol was examined and approved by the Research Ethics Committee of the University of São Paulo (USP) (number: 0170/09) and Universidade Federal de São Paulo (Unifesp/EPM) (number: 0229/04) and the participants who agreed to participate in the study gave written informed consent.

\section{Collection of clinical information}


Standardized questionnaires were used to verify the demographic characteristics and medical history. Menopause was defined as more than 12 months since the last menstrual period [21].

\section{Evaluation of food intake}

Dietary intake information was collected using a quantitative Food Frequency Questionnaire (FFQ), consisting of 62 food items and validated in Brazil [22]. The FFQ was administered by a trained nutritionist and the information provided reflected the pattern of food intake for the last six months. Portion size was evaluated with the aid of a food portion photo set.

Foods were systematically grouped together on the basis of similarities of food and nutrient composition, thus reducing the 62 foods to 10 food groups. The following food groups were formed: food rich in fat (butter, margarine, olive oil, soybean oil, mayonnaise and mayonnaise salad); alcoholic beverages (fermented and distilled); non-alcoholic beverages (tea, coffee and soft drink); meat and eggs (beef, pork, poultry, fish, quail egg, chicken egg and omelet); processed meat (sausage, salami and ham); cereals and tubercles (rice, potatoes, bread, crackers, ,pasta, pastry, cassava and maize flour); sweets (deserts, cookies with filling, ice-cream, jam, chocolate and suggar); fruits and vegetables (banana, grape, orange, tangerine, papaya, apple, pear, watermelon, cantaloupe, mango, pineapple, guava, persimmon, natural fruit juice, lettuce, chard, tomatoes, cabbage, spinach, beets, carrots, cucumbers, peppers, eggplant, broccoli, cauliflower and soup vegetables); beans ( beans, peas, lentils and soybean); dairy products (milk, yogurt and cheese).

\section{Evaluation of physical activity}

Since physical activity is a potent confounding factor. The level of physical activity (PA) was assessed through the Baecke Questionnaire of Habitual Physical Activity [23]. This tool evaluates three PA's main components: work, sport and leisure. All the answers, with the exception of the occupation activity and the type of sport, were precoded on a scale of 5 points, with descriptors that range from never (1) to very often (5). The level of occupational activity was classified as low (1), 
medium (3) or high (5). The score of sport activities was calculated by the equation: [intensity code $\mathrm{x}$ duration code $\mathrm{x}$ year proportion code] $\mathrm{x} 1.25$. If there was more than one sport practiced, the values were added. As a result, each component of PA can receive a maximum of five points, with a maximum score of 15 . Each index was rounded to the nearest tenth of the unit or point.

\section{Anthropometry}

All individuals were measured and weighed on a standard balance beam scale (Filizola $\left.{ }^{\circledR}\right)$, calibrated periodically, wearing light clothes and without shoes. Weight was measured to the nearest $100 \mathrm{~g}$. Standing height was measured with the aid of a stadiometer (Filizola $($ ) by a trained individual. Body mass index (BMI) was calculated by the ratio between weight $(\mathrm{kg})$ and height, in meters squared $\left(\mathrm{kg} / \mathrm{m}^{2}\right)$.

\section{Assessment of body composition and bone mineral density measurements}

BMD assessment was performed on the lumbar spine (L1-L4) and femoral neck $\left(\mathrm{g} / \mathrm{cm}^{2}\right)$ by using dual energy X-ray absorptiometry (DXA), DPX MD + densitometer (GE-Lunar Radiation Corporation, Madison, WI, USA). A well-trained technician followed a standard protocol. Quality control was done daily and phantom cross-calibration three times per week. For premenopausal women, Z-score was used in compliance with International Society of Clinical Densitometry (ISCD) recommendations [24] and supported by the Brazilian Society of Clinical Densitometry (SBDens), a national regulatory agency [25].

Body composition was also measured by DXA. Total body fat mass was evaluated in absolute values as body fat $(\mathrm{kg})$ and percentage $(\mathrm{BF} \%)$. Lean mass was defined as fat free mass (FFM), with special emphasis to appendicular lean mass (ALM) and the relative skeletal muscle index (RSMI). For women aged over 50 years, sarcopenia was defined according to the classification of Baumgartner [26], in which RSMI values below two standard deviations relative to young healthy population or less than $5.45 \mathrm{~kg} / \mathrm{m}^{2}$, for women; indicative of that condition. For younger women, the criterion was not used. RSMI is the ratio of appendicular lean mass $(\mathrm{kg})$ and height squared $\left(\mathrm{m}^{2}\right)$. 
The coefficient of variation was $1.5 \%$ for the lumbar spine and total body and $2 \%$ for the femoral neck.

\section{$\underline{\text { Radiographic evaluation }}$}

Radiographic evaluation of dorsal and lumbar spine in anteroposterior and lateral positions was performed by a rheumatologist blinded for clinical data and specific procedures of the protocol data in order to exclude vertebral degenerative processes, as well as other causes of high BMD, including bone metastases, Paget's disease, fracture or congenital deformities (Schmorl's nodes, severe scoliosis). The image acquisition protocol followed the recommendation of $120 \mathrm{~cm}$ for tube film distance and X-ray beams centered in T8 and L3, respectively.

\section{$\underline{\text { Statistical analysis }}$}

The results were analyzed as mean $\pm \mathrm{SD}$. The Kolmogorov-Smirnov test was used to verify the normal distribution of variables. Mean differences between groups were assessed by Student's t-test. P-values of $<0.05$ were considered significant.

Dietary patterns were obtained by exploratory factor analysis of the ten food groups. The data was verified using the Kaiser-Meyer-Olkin (KMO) measurement of sample adequacy and the Barlett Test of Sphericity (BTS), wich tests the presence of correlations between variables [27].

The choice of the number of factor was first based on the Kaiser criterion, namely eigenvalues over 1.0. This is the most frequently used criterion in factor analysis, and the theoretical basis behind it is that each retained factor should explain more variance then the original variable in the data set. All analyses were performed with the aid of Statistical Package for the Social Sciences, version 16.5 for Windows (SPSS Inc., Chicago, IL).

\section{Results}

Table 1 presents the distribution of cases and controls according to BMD. The groups were matched for age, weight, BMI, smoking, fat mass and menopausal status. In both groups, the prevalence of overweight was high, but without significant 
difference between them. Nevertheless, women with high BMD had higher FFM and $\operatorname{ALM}(\mathrm{p}<0.05)$.

The dietary pattern is demonstrated in Table $\mathbf{2}$ and $\mathbf{3}$, according to BMD. Five Components were identified through factor analysis, based on the Kaiser criterion. The observed KMO was 0.5 in both groups, indicating that the sample was considered to be adequate for factor analysis. These five components accounted for $75.4 \%$ and $75.1 \%$ of the variability within the sample in HBMD and health controls group, respectively.

The HBMD group had the first principal component, which accounted for $20 \%$ of the total variance. Cereals, tubercles and beans characterized this factor. On the other hand, foods rich in fat, processed meat, fruit and vegetables, were responsible for $21 \%$ of the total variance in healthy controls.

The second principal component explained $18 \%$ and $16.5 \%$ of the total variance in HBMD and health control, respectively. This factor was characterized by meats, eggs and dairy products in both groups. In addition fruit, vegetables and sweets are present in HBMD group; beans in health control with low consumption of alcoholic beverage.

The third principal component in HBMD was characterized by low consumption of processed meat, $15 \%$ of the total variance. In health control beans are the high factor loading, $14 \%$ of the total variance.

Foods rich in fat explained the fourth principal component in HBMD group $(11.5 \%)$, while in health control cereals and tubercles explain $12.3 \%$ of the total variance. The fourth feature in health control is low consumption of sweets.

In fifth principal component it is worth noting the opposition to the results. While the HBMD women had low consumption of soft drinks, control group presents a high consumption of these drinks. This factor explained $10.2 \%$ and $10.9 \%$ of the total variance in HBMD and control group, respectively.

\section{Discussion}

To our knowledge, this is the first study using principal component analysis to compare dietary pattern in HBMD and normal BMD. Five patterns that explained approximately $75 \%$ of the total variability of diet in each group were identified. 
The HBMD group appeared to had a healthier diet. Cereals, tubercles, beans, dairy products, fruit, vegetables, sweets, meats and eggs, with low processed meat, explained more than $50 \%$ of the total variance. These foods contain nutrients that are associated with bone health. On the other hand control group presented a dietary patterns constituted with a processed meat, food rich in fat and low alcoholic beverages, which differ the other group. Apart from these, fruit, vegetables, beans, dairy products, meat, eggs also were part of the dietary pattern.

The consumption of cereals and tubercles was found in PCl in women with HBMD and in PC4 in control group. Tucker (2002), using cluster analysis in men and women aged 60-93 years, identified a dietary pattern rich in fruit, vegetables and cereal group with a highest BMD in men [28]. According to recommendation of DRIs, cereals should be the basis of a healthy diet, giving preference to the wholegrain [29].

Beans, meat and eggs are high in protein. It's one of the main components of the bone matrix, however the relationship between dietary protein and bone health is controversial. There is the hypothesized that animal protein provides a higher dietary acid load than does vegetable protein, and as a consequence bone is lost, perhaps as a result of increased calcium excretion and negative calcium balance induced by acid load. However, other studies have not supported an association of negative calcium balance with animal compared with vegetable protein sources [30, 31]. In general terms, protein intake has been associated with a bone benefit, as noted in two metaanalysis. The first has called the dietary acid-ash hypothesis of bone loss into question [32] and the second show that protein intake reduces bone resorption markers and has a small positive association with BMD and BMC [33].

According to Hardcastle, 2011 the decreased of bone resorption observed in "healthy" dietary pattern, in a cross-sectional study with 3236 women, may be explained by eating foods that provide adequate protein [31]. According in ourr previous study protein intake was one of the protection factors associated with high BMD in healthy women [35]. In this study the vegetable protein was present in $\mathrm{PC1}$, while the meat and eggs stood out in PC2, therefore there a greater contribution from vegetable protein in women with HBMD. Independent of the protein it is present in a positive manner in both groups. 
The dairy products in both groups are present in PC2. Hardcaltle (2011) using principal components analysis, based on 35 food groups, reported a positive contribution of dairy products, excluding milks [31]. Mc Naughton (2011) identified a beneficial association of dietary pattern consisted of legumes, seafood, seed and nuts, wine, rice and rice dishes, and other vegetables and vegetables dishes. These data suggest that other dietary factors could contribute to bone density when there is a low calcium intake [16].

The Framingham Osteoporosis Study, using cluster analysis, reported lower femoral neck BMD in elderly men in association with the 'candy cluster', but not in women [28]. In our results the sweets are in PC2 in HBMD women and with low consumption in control group (PC4) and explain of $18 \%$ and $12.3 \%$ of variability, respectively.

Despite the high-fat foods are present in both groups they were significant only in the fourth component in HBMD women. In our previous study we found the fat intake had a negative role in HBMD women. [35].It has been shown that dietary patterns such as the Western dietary pattern identified in the Nurses' Health Study and those high in fats, processed meat, and other high-energy foods, were directly associated with inflammatory markers such as c-reactive protein and IL-6 [36-39]. Inflammatory markers such as C-reactive protein and IL-6 have previously been shown to be associated with low BMD and increasing bone loss [40-42].

Maybe the presence of fruit and vegetables was an important contributor in HBMD and a protective factor for the control group, which maintained bone mass within the normal range in our study. According to Hardcastle, 2011. a diet rich in fruit and vegetables may reduce bone resorption [31].These foods have a negative potential renal acid load, wich may be important for bone health [43]. Tucker (2002) in Framingham Osteoporosis Study, investigated older adults and identified a diet high in fruit, vegetable and cereals had significantly greater BMD in men, but not in women [28].

It's interesting observed that processed meat in women with normal BMD appear in PC1 $(21.2 \%)$ and in women with HBMD there are a lower intake of these in PC3 (15.4\%). Okubo identified a dietary pattern including fish, fruits, and 
vegetables, and low in meat and processed meat was associated with higher BMD in pre-menopausal Japanese women [12].

Increased intake of fruit, vegetables and low-fat dairy products is emphasized in the Dietary Approaches to Stop Hypertension, and a randomized trial based on this intervention was shown to reduced bone turnover, serum osteocalcin by $8-11 \%$ and C-terminal telopeptide of type I collagen by $16-18 \%$, and low sodium intake reduced calcium excretion in the DASH diet and control groups and serum osteocalcin in the DASH group [44].

The non-alcoholic beverage had opposite results between the groups (PC5). The relationship with BMD is controversial. Okubo (2006) didn't found association between beverage pattern and BMD among Japanese women [12]. On the other hand Tucker (2006) in Framingham Osteoporosis Study found an intake of cola, but not of other carbonated soft drinks, is associated with low BMD in women [45]. In animal models caffeine may reduce BMD through the enhancement in osteoclastogenesis [46].

Factor analysis is the most commonly used method to date to derive dietary patterns. Uses the variations in food intakes that exist in a population to create factors, or latent variables, which are defined by the foods whose consumption is highly correlated with the factor [47]

Describing food intake in patterns may be particularly useful in developing counseling programs [48].

Dietary patterns were not measured directly, but relied on reported FFQ. The use of FFQ to estimate intakes is not without error; however, they are accepted as standard.

In our analysis we identified a healthier, balanced dietary with cereals, tubercles, beans, dairy products, fruit, vegetables, sweets, meats and eggs, with low of processed meat in women with high BMD. This dietary pattern could be a potential public policy strategies improving bone health. 
Table 1: Anthropometric, clinical and body data of the population, according to BMD

\begin{tabular}{|c|c|c|c|}
\hline & $\begin{array}{l}\text { Healthy controls } \\
(\mathrm{N}=40)\end{array}$ & $\begin{array}{l}\text { HBMD } \\
(\mathrm{N}=40)\end{array}$ & $\mathrm{p}$ \\
\hline Age (years) & $51(8.5)$ & $50.9(8.2)$ & 0.989 \\
\hline Weight (kg) & $61.7(6.7)$ & $64.3(5.2)$ & 0.052 \\
\hline BMI $\left(\mathrm{kg} / \mathrm{m}^{2}\right)$ & $25.2(2.6)$ & $25.6(2.4)$ & 0.497 \\
\hline Age of menarche (years) & $13.0(1.4)$ & $13.0(2.4)$ & 0.913 \\
\hline Smoking packets-year & $26.2(27.7)$ & $16.7(19.3)$ & 0.290 \\
\hline TPA index (score) & $7.9(1.3)$ & $7.6(1.2)$ & 0.412 \\
\hline \multicolumn{4}{|l|}{ Bone Mineral Density } \\
\hline Lumbar spine $\left(\mathrm{g} / \mathrm{cm}^{2}\right)$ & $1.209(0.1)$ & $1.408(0.1)^{*}$ & $<0.001$ \\
\hline Femoral neck $\left(\mathrm{g} / \mathrm{cm}^{2}\right)$ & $0.986(0.08)$ & $1.119(0.1)^{*}$ & $<0.001$ \\
\hline Total femoral $\left(\mathrm{g} / \mathrm{cm}^{2}\right)$ & $1.043(0.2)$ & $1.166(0.1)^{*}$ & $<0.001$ \\
\hline \multicolumn{4}{|l|}{ Body Composition } \\
\hline FFM (kg) & $34.4(3.9)$ & $36.4(4.1)^{*}$ & 0.029 \\
\hline ALM (kg) & $15.0(1.7)$ & $16.1(1.9)^{*}$ & 0.007 \\
\hline $\operatorname{RSMI}\left(\mathrm{kg} / \mathrm{m}^{2}\right)$ & $6.1(0.7)$ & $6.3(0.7)$ & 0.278 \\
\hline Body fat (\%) & $40.5(6.0)$ & $39.4(6.8)$ & 0.433 \\
\hline Total body fat mass $(\mathrm{kg})$ & $23.6(5.4)$ & $24.0(4.8)$ & 0.740 \\
\hline
\end{tabular}

Student's T Test

BMI: Body Mass Index; TFA: Total Physical Activity; FFM: Total Fat-Free Mass; ALM: Appendicular Lean Mass; RSMI: Relative Skeletal Muscle Index. 
Table 2: The five components (dietary patterns) identified from the food frequency questionnaires using factor analysis in HBMD

Dietary pattern

\begin{tabular}{llllll}
\cline { 2 - 5 } Food Group & $\begin{array}{l}\text { PC1 } \\
(\text { scores })\end{array}$ & $\begin{array}{l}\text { PC2 } \\
\text { (scores) }\end{array}$ & $\begin{array}{l}\text { PC3 } \\
\text { (scores) }\end{array}$ & $\begin{array}{l}\text { PC4 } \\
\text { (scores) }\end{array}$ & $\begin{array}{l}\text { PC5 } \\
\text { (scores) }\end{array}$ \\
\hline Food rich in fat & 0.176 & 0.352 & 0.156 & 0.775 & 0.287 \\
\hline Alcoholic beverages & -0.235 & -0.359 & 0.472 & 0.050 & 0.241 \\
\hline Non-alcoholic beverages & 0.384 & 0.068 & 0.468 & 0.404 & -0.558 \\
\hline Meats and eggs & 0.272 & 0.542 & 0.085 & -0.181 & 0.628 \\
\hline Processed meat & 0.251 & -0.001 & -0.794 & 0.119 & 0.051 \\
\hline Cereals and tubercles & 0.866 & 0.175 & 0.026 & -0.093 & -0.100 \\
\hline Sweets & -0.245 & 0.590 & -0.533 & 0.223 & -0.235 \\
\hline Fruit and vegetables & -0.355 & 0.653 & 0.331 & 0.029 & 0.074 \\
\hline Beans & 0.850 & -0.062 & 0.064 & -0.184 & 0.076 \\
\hline Dairy products & -0.084 & 0.663 & 0.201 & -0.498 & -0.308 \\
\hline Eigenvalues & 2.022 & 1.801 & 1.543 & 1.154 & 1.020 \\
\hline \% Explained variance & 20.216 & 18.008 & 15.425 & 11.538 & 10.198 \\
\hline
\end{tabular}

Factor Analysis

PC: Principal Component 
Table 3: The five components (dietary patterns) identified from the food frequency questionnaires using factor analysis in healthy controls

Dietary pattern

\begin{tabular}{llllll}
\cline { 2 - 5 } Food Group & $\begin{array}{l}\text { PC1 } \\
(\text { scores })\end{array}$ & $\begin{array}{l}\text { PC2 } \\
\text { (scores) }\end{array}$ & $\begin{array}{l}\text { PC3 } \\
\text { (scores) }\end{array}$ & $\begin{array}{l}\text { PC4 } \\
\text { (scores) }\end{array}$ & $\begin{array}{l}\text { PC5 } \\
\text { (scores) }\end{array}$ \\
\hline Food rich in fat & 0.617 & 0.344 & -0.295 & 0.151 & 0.235 \\
\hline Alcoholic beverages & 0.336 & -0.605 & 0.202 & 0.434 & 0.111 \\
\hline Non-alcoholic beverages & 0.475 & 0.324 & -0.258 & -0.321 & 0.554 \\
\hline Meats and eggs & -0.475 & 0.503 & -0.257 & 0.278 & 0.370 \\
\hline Processed meat & 0.753 & -0.011 & 0.355 & 0.288 & 0.105 \\
\hline Cereals and tubercles & -0.312 & 0.385 & 0.462 & 0.568 & 0.243 \\
\hline Sweets & 0.412 & 0.298 & 0.361 & -0.502 & -0.124 \\
\hline Fruit and vegetables & 0.561 & -0.030 & -0.466 & 0.373 & -0.306 \\
\hline Beans & 0.179 & 0.550 & 0.586 & 0.018 & -0.276 \\
\hline Dairy products & 0.001 & 0.517 & -0.315 & 0.213 & -0.566 \\
\hline Eigenvalues & 2.126 & 1.651 & 1.414 & 1.233 & 1.086 \\
\hline \% Explained variance & 21.262 & 16.513 & 14.144 & 12.333 & 10.864 \\
\hline
\end{tabular}

Factor Analysis

PC: Principal Component 


\section{References:}

1- Gregson CL, Rittweger J, Lazar V, Steel S, Tobias JH. The high bone mass phenotype is characterized by increased trabecular density and reduced endosteal expansion. ASBMR, 2009.

2- Orwoll ES, Bevan L, Phipps KR: Determinants of bone mineral density in older men. Osteoporos Int 2000, 11:815-21.

3- Bell NH: Bone and mineral metabolism in African Americans. Trends Endocrinol Metab 1997, 8: 240-5.

4- Van Wesenbeeck L, Cleiren E, Gram J, Beals RK, Bénichou O, Scopelliti D, Key L, Renton T, Bartels C, Gong Y, Warman ML, De Vernejoul MC, Bollerslev J, Van Hul W: Six novel missense mutations in the LDL receptor-related protein 5 (LRP5) gene in different conditions with an increased bone density. Am J Hum Genet 2003, 72: $763-71$.

5- Pasco JA, Kotowicz MA, Henry MJ, Sanders KM, Nicholson GC; Geelong Osteoporosis Study: Statin use, bone mineral density, and fracture risk: Geelong Osteoporosis Study. Arch Intern Med 2002, 162: 537-40

6- Kamel HK: Low-dose thiazide and bone density. Ann Intern Med 2002,136: 2523.

7- Cauley JA, Lucas FL, Kuller LH, Vogt MT, Browner WS, Cummings SR: Bone mineral density and risk of breast cancer in older women: the study of osteoporotic fractures. Study of Osteoporotic Fractures Research Group. JAMA 1996, 276: 1404 -8 .

8- Whyte MP, Mills BG, Reinue WR, Podgomik MN, Roodman GD, Gannon FH, Eddy MC, McAlister WH: Espnasile skeletal hyperphosphatasia: a new familial metabolic bone disease. J Bone Miner Res 2000, 15: 2330-44.

9- Trutschnigg B, Chong C, Habermayerova L, Karelis AD, Komorowski J: Female boxers have high bone mineral density despide low fat mass, high energy expenditure, and high inidence of oligomenorrhea. Appl Physiol Nutr Metab 2008, 33:863-869.

10- Heaney RP, Recker RR, Stegman MR, Moy AJ: Calcium absorption in women: relationships to calcium intake, estrogen status, and age. J Bone Miner Res 1989, 4: 469-475. 
11- Qin X, Wang S, Yu M, Zhang L, Li X, Zuo Z, Zhang X, Wang L: Child Skeletal Fluorosis from Indoor Burning of Coal in Southwestern China. J Environ Public Health 2009, 2009: 969764.

12- Okubo H, Sasaki S, Horiguchi H, Oguma E, Miyamoto K, Hosoi Y, Kim MK, Kayama F Dietary patterns associated with bone mineral density in premenopausal Japanese farmwomen. Am J Clin Nutr. 2006 May;83(5):1185-92.

13- Hu FB, Rimm EB, Stampfer MJ, e cols.. Prospective study of major dietary patterns and risk of coronary heart disease in men. Am J Clin Nutr 2000, 72: 912 921.

14- Newby PK e Tucker KL (2004) Empirically derived eating patterns using factor or cluster analysis: a review. Nutr Rev 62, 177-203.

15- Kennedy ET, Ohls J, Carlson S, e cols.. (1995) The Healthy Eating Index: design and applications. J Am Diet Assoc 95,1103-1108

16- McNaughton SA, Wattanapenpaiboon N, Wark JD, Nowson CA. An energydense, nutrient-poor dietary pattern is inversely associated with bone health in women.J Nutr. 2011 Aug;141(8):1516-23. Epub 2011 Jun 8.

17- Whittle CR, Woodside JV, Cardwell CR, McCourt HJ, Young IS, Murray LJ, Boreham CA, Gallagher AM, Neville CE, McKinley MC. Dietary patterns and bone mineral status in young adults: the Northern Ireland Young Hearts Project. Br J Nutr. 2012 Jan 4:1-11. [Epub ahead of print]

18- Kontogianni MD, Melistas L, Yannakoulia M, Malagaris I, Panagiotakos DB, Yiannakouris N. Association between dietary patterns and indices of bone mass in a sample of Mediterranean women. Nutrition. 2009 Feb;25(2):165-71. Epub 2008 Oct 11

19- World Health Organization (WHO): Assessment of fracture risk and its application to screening for postmenopausal osteoporosis. Report of a WHO Study Group. World Health Organ Tech Rep Ser 1994, 84: 31-129.

20- Dawson DA, Grant BF, Li TK: Quantifying the risks associated with exceeding recommended drinking limits. Alcohol Clin Exp Res 2005, 29: 902-908.

21- Butler L, Santoro N: The reproductive endocrinology of the menopausal transition. Steroids 2011, 76: 627-35.

22- Pereira GA, Genaro PS, Sarkis KS, Peters BSE, Santos LC, Martins TA, Martini LA: Validação do questionário de freqüência alimentar para mulheres com osteoporose. Nutrire 2005, 30: 85 
23- Baeck JA, Jurema J, Frijters JE: A short questionnaire for the measurement of habitual activity in epidemiological studies. Am J Clin Nutri 1982, 36:936-42

24- Baim S, Binkley N, Bilezikian JP, Kendler DL, Hans DB, Lewiecki EM, Silverman S. Official Positions of the International Society for Clinical Densitometry and executive summary of the 2007 ISCD Position Development Conference. J Clin Densitom. 2008 Jan-Mar;11(1):75-91

25- Brandão CMA, Camargos BM, Zerbini CA, Plapler PG, Mendonça LM, Albergaria BH, Pinheiro MM, Prado M, Eis SR: Posições Oficiais 2008 da Sociedade Brasileira de Densitometria Clínica (SBDens). Arq Bras Endocrinol Metabol 2009, 53:107-12.

26- Baumgartner RN, Stauber PM, Koehler KM, Romero L, Garry PJ: Associations of fat and muscle masses with bone mineral in elderly men and women. Am J Clin Nutr 1996, 63: 365-72.

27- Fávero, L. P., Belfiore, P., da Silva, F.L., Chan, B.L. Análise de Dados Modelagem Multivariada para Tomada de Decisões, - Editora Elsevier (2009).

28- Tucker KL, Chen H, Hannan MT, e cols.. (2002) Bone mineral density and dietary patterns in older adults: the Framingham Osteoporosis Study. Am J Clin Nutr $76,245-252$

29- Food and Nutrition Board, Institute of Medicine. Dietary Reference Intakes for Energy, Carbohydrate, Fiber, Fat, Fatty Acids, Cholesterol, Protein, and Amino Acids (Macronutrients). Washington DC: National Academy Press, 2005.

30- Kerstetter JE, Wall DE, O'Brien KO, Caseria DM, Insogna KL. Meat and soy protein affect calcium homeostasis in healthy women. J Nutr2006;136:1890-5.

31- Roughead ZK, Hunt JR, Johnson LK, Badger TM, Lykken GI. Controlled substitution of soy protein for meat protein: effects on calcium retention, bone, and cardiovascular health indices in postmenopausal women. J Clin Endocrinol Metab 2005;90:181-9.

32- Fenton TR, Lyon AW, Eliasziw M, Tough SC, Hanley DA. Metaanalysis of the effect of the acid-ash hypothesis of osteoporosis on calcium balance. J Bone Miner Res 2009;24:1835-40.

33- Darling AL, Millward DJ, Torgerson DJ, e cols.. (2009) Dietary protein and bone health: a systematic review and metaanalysis. Am J Clin Nutr 90, 1674-1692.

34- Hardcastle AC, Aucott L, Fraser WD, Reid DM, Macdonald HM. Dietary patterns, bone resorption and bone mineral density in early post-menopausal Scottish women. Eur J Clin Nutr. 2011 Mar;65(3):378-85. Epub 2010 Dec 22. 
35- Sarkis KS, Martini LA, Szejnfeld VL, Pinheiro MM. Low fatness, reduced fat intake and adequate plasmatic concentrations of LDL-cholesterol are associated with high bone mineral density in women: a cross-sectional study with control group. Lipids Health Dis. 2012 Mar 12;11:37.

36- Giugliano D, Ceriello A, Esposito K. The effects of diet on inflammation: emphasis on the metabolic syndrome. J Am Coll Cardiol.2006;48:677-85.

37- Dai J, Miller AH, Bremner JD, Goldberg J, Jones L, Shallenberger L,Buckham , Murrah NV, Veledar E, e cols.. Adherence to the Mediterranean diet is inversely associated with circulating interleukin-6 among middle-aged men: a twin study. Circulation. 2008;117:169-75.

38- Nettleton JA, Steffen LM, Mayer-Davis EJ, Jenny NS, Jiang R, Herrington DM, Jacobs DR Jr. Dietary patterns are associated with biochemical markers of inflammation and endothelial activation in the Multi-Ethnic Study of Atherosclerosis (MESA). Am J Clin Nutr. 2006 Jun;83(6):1369-79.

39- Fung TT, McCullough ML, Newby PK, Manson JE, Meigs JB, Rifai N, Willett WC, Hu FB. Diet-quality scores and plasma concentrations of markers of inflammation and endothelial dysfunction. Am J Clin Nutr. 2005 Jul;82(1):163-73.

40- Koh JM, Khang YH, Jung CH, Bae S, Kim DJ, Chung YE, Kim GS.Higher circulating hsCRP levels are associated with lower bone mineral density in healthy pre- and postmenopausal women: evidence for a link between systemic inflammation and osteoporosis. Osteoporos Int. 2005; 16:1263-71.

41-Scheidt-Nave C, Bismar H, Leidig-Bruckner G, Woitge H, Seibel MJ, Ziegler R, Pfeilschifter J. Serum interleukin 6 is a major predictor of bone loss in women specific to the first decade past menopause. J Clin Endocrinol Metab. 2001;86:203242.

42- Cauley JA, Danielson ME, Boudreau RM, Forrest KY, Zmuda JM, Pahor M, Tylavsky FA, Cummings SR, Harris TB, e cols.. Inflammatory markers and incident fracture risk in older men and women: the Health Aging and Body Composition Study. J Bone Miner Res. 2007;22:1088-95.

43- Lanham-New SA. The balance of bone health: tipping the scales in favor of potassium-rich, bicarbonate-rich foods. J Nutr. 2008;138:S172-7.

44- Lin PH, Ginty F, Appel LJ, Aickin M, Bohannon A, Garnero P, e cols.. The DASH diet and sodium reduction improve markers of bone turnover and calcium metabolism in adults. J Nutr 2003;133:3130-6.

45- Tucker KL, Morita K, Qiao N, Hannan MT, Cupples LA, Kiel DP. Colas, but not other carbonated beverages, are associated with low bone mineral density in older women: The Framingham Osteoporosis Study. Am J Clin Nutr. 2006 Oct;84(4):93642 . 
46- Liu SH, Chen C, Yang RS, Yen YP, Yang YT, Tsai C. Caffeine enhances osteoclast differentiation from bone marrow hematopoietic cells and reduces bone mineral density in growing rats. J Orthop Res. 2011 Jun;29(6):954-60. doi: 10.1002/jor.21326. Epub 2011 Jan 31.

47- Kline P. An easy guide to factor analysis. London: Routledge, 1994.

48- Gallagher MI, Farrior E, Broadhead L, e cols.. Development and testing of a food frequency recall instrument for describing dietary patterns in adult and teenagers. Nutr Res 1993;13:177-88. 


\section{CONSIDERAÇÕES FINAIS}

A alta prevalência de osteoporose e de fraturas por fragilidade óssea a nível mundial ressalta a importância de buscar a prevenção e novas estratégias de tratamento. Atualmente, acreditamos que a densidade mineral óssea elevada e saúde óssea são importantes para a osteoporose. Portanto, a identificação de fatores envolvidos no aumento da densidade mineral óssea de aplicabilidade possível, em populações de risco, se mostra de grande relevância.

Existem diversos fatores etiológicos envolvidos na elevada densidade mineral óssea, sendo que dentre os fatores modificáveis encontram-se a composição corporal, o perfil lipídico e a alimentação.

$\mathrm{O}$ presente estudo observou que a massa magra esquelética apresentou-se como preditor positivo para a DMO do fêmur, estando significamente aumentada em mulheres com EDMO. Efeito contrário foi observado em relação à massa gorda $\mathrm{e}$ concentrações séricas de LDL-colesterol para o mesmo sítio. Além disso, o consumo de lipídios foi preditor negativo para DMO do corpo total.

Adicionalmente foi observado que um padrão alimentar saudável, composto por cereais, tubérculos, leguminosas, lácteos, hortaliças, doces, carnes e ovos com baixo consumo de carnes processadas e bebidas açúcaradas, bem como um consumo moderado de alimentos ricos em gordura é realizado por mulheres com EDMO.

Desta forma, podemos concluir que a adequação do perfil de lipídeos séricos, representado pelo LDL-colesterol, e o desenvolvimento da massa magra, através de atividade fisica assistida, seja de grande valia para incremento e manutenção da DMO. Em relação ao consumo alimentar acreditamos que e a adequação da alimentação como um todo seja necessária, principalmente preconizando a moderação para consumo de carnes processadas e alimentos ricos em gordura. Estes pontos deveriam ser considerados no planejamento e na implementação de ações preventivas em populações de risco para redução da massa óssea e até mesmo como forma de tratamento. 


\section{REFERÊNCIAS BIBLIOGRÁFICAS}

Adami S, Braga V, Zamboni M, Gatti D, Rossini M, Bakri J, Battaglia E Relationship between lipids and bone mass in 2 cohorts of healthy women and men. Calcif Tissue Int 2004; 74: 136-142.

Adami S, Gatti D, Viapiana O, Fiore CE, Nuti R, Luisetto G, Ponte M, Rossini M, On Behalf of the BONTURNO Study Group. Physical activity and bone turnover markers: a cross-sectional and a longitudinal study. Calcif Tissue Int. 2008; 83:388392.

Ainsworth BE, Haskell WL, Herrmann SD, Meckes N, Bassett DR Jr, Tudor-Locke C, Greer JL, Vezina J, Whitt-Glover MC, Leon AS. 2011 Compendium of Physical Activities: a second update of codes and MET values. Med Sci Sports Exerc. 2011;43(8):1575-81.

Albala C, Yanez M, Devoto E, Sostin C, Zeballos L, Santos JL. Obesity as a protective factor for postmenopausal osteoporosis. Int J Obesity 1996;20:1027-32.

Alfredson H, Nordström P, Lorentzon R Total and regional bone mass in female soccer players. Calcif Tissue Int. 1996;59(6):438-42.

Alfredson H, Nordström P, Lorentzon R Long-term Loading and Regional Bone Mass of the Arm in Female Volleyball Players Calcif Tissue Int. 1998; 62:303-308

Aloia JF, Vaswani A, Mikhail M, Flaster ER. Body composition by dual-energy Xray absorptiometry in black compared with white women. Osteoporos Int 1999; 10:114-119.

American College of Sports Medicine. Physical activity and bone health. Med Sci Sports Exerc 2004 disponível em http://www.acsm-msse.org acesso em 05 de maio de 2009). 
Ammann P, Bourrin S, Bonjour JP, Meyer JM, Rizzoli R. Protein undernutritioninduced bone loss is associated with decreased IGF-1 levels and estrogen deficiency. JBMR. 2000;15(4):683-690.

Arabi A, Baddoura R, El-Rassi R, El-Hajj Fuleihan G. PTH level but not 25 (OH) vitamin D level predicts bone loss rates in the elderly. Osteoporos Int. 2012 Mar;23(3):971-80. Epub 2011 Jun 8.

Baecke JA, jurema J, Frijters JE. A short questionnaire for the measurement of habitual activity in epidemiological studies. Am J Clin Nutri. 1982;36:936-42

Bandeira F, Griz, L, Freese E; Lima DC, Thé AC, Diniz ET, Marques TF, CS. Deficiência de vitamina $\mathrm{D}$ e sua relação com a densidade mineral óssea em mulheres na pós-menopausa residentes nos trópicos. Arq. Bras Endocrinil Metab. 2010;54(2):85-86.

Baron JA, Barrett J, Malenka D, Fisher E, Kniffin W, Bubolz T, Tosteson T. Racial differences in fracture risk. Epidemiology. 1994 Jan;5(1):42-7

Baron R. FSH versus estrogen: Who's guilty of breaking bones? Cell Metab. 2006;3 (5):302-5.

Baumgartner RN, Stauber PM, Koehler KM, Romero L, Garry PJ. Associations of fat and muscle masses with bone mineral in elderly men and women. Am J Clin Nutr. 1996; 63(3):365-72.

Bassey EJ, Rothwell MC, Little JJ, Pye DW Pre- and postmenopausal women have different bone mineral density responses to the same high impact exercise. $J$ Bone Miner Res.1998; 13:1805-1813.

Bell NH. Bone and mineral metabolism in African Americans. Trends Endocrinol Metab. 1997 Aug;8(6):240-5. 
Bizik BK, Ding W, Cerlewski FL. Evidence that bone resorption of young men is not increased by high dietary phosphorus obtained from milk and cheese. Nutrition Research. 1996; 16: 1143-6

Bolland MJ, Ames RW, Horne AM, Orr-Walker BJ, Gamble GD, Reid IR. The effect of treatment with a thiazide diuretic for 4 years on bone density in normal postmenopausal women. Osteoporos Int. 2007;18:479-486

Borba VZC, Kulak CAM, Lazaretti-Castro M. Controle Neuroendócrino da Massa Óssea:Mito ou Verdade? Arq Bras Endocrinol Metab. 2003; 47 (4):453-457.

Borer KT. Physical activity in the prevention and amelioration of osteoporosis in women : interaction of mechanical, hormonal and dietary factors.Sports Med. 2005;35(9):779-830. Review.

Bourrin S. Toromanoff A, Ammann P, Bonjour JP, Rizzoli R. Dietary protein deficiency induces osteoporosis in aged male rats. JBMR. 2000;15(8):1555-63.

Boyle, W.J., Simonet, W.S., and Lacey, D.L. Osteoclast differentiation and activation Nature 2003, 423: 337-342.

Broadus AE. Mineral balance and homeostasis In: Favus ML. Primer on the Metabolic Bone Diseases and Disorders of Mineral Metabolism.Washington DC: American Society for Bone and Mineral Research; 2003 p.105-111.

Buhaescu I, Izzedine H. Mevalonate pathway: a review of clinical and therapeutical implications. ClinBiochem 2007; 40: 575-584.

Bucher HC, Griffith LE, Guyatt GH. Systematic review of the risk and benefit of different cholesterol-lowering interventions. Arterioscler Thromb Vasc Biol 1999;19: 187-95. 
Bueno MB, Cesar CLG, Martini LA, Fisberg RM Dietary calcium intake and overweight: An epidemiologic view. Nutrition 2008; 24 (11-12): 1110-1115

Cadore EL, Brentano MA, Kruel LFM. Efeitos da atividade física na densidade mineral óssea e na remodelação do tecido ósseo. Rev Bras Med Esporte. 2005; 11(6):373-379.

Calvo MS, Kumar R, Heath H 3rd. Persistently elevated parathyroid hormone secretion and action in young women after four weeks of ingesting high phosphorus, low calcium diets. Journal of Clinical Endocrinology and Metabolism 1990; 70: $1334-40$.

Cauley JA, Lucas FL, Kuller LH, Vogt MT, Browner WS, Cummings SR. Bone mineral density and risk of breast cancer in older women: the study of osteoporotic fractures. Study of Osteoporotic Fractures Research Group. JAMA $1996 ; 276: 1404$ -8 .

Chan MH, Mak TW, Chiu RW, et al. Simvastatin increases serum osteocalcin concentration in patients treated for hypercholesterolaemia. J Clin Endocrinol Metab $2001 ; 86: 4556$.

Chantler S, Dickie K, Goedecke JH, Levitt NS, Lambert EV, Evans J, Joffe Y, Micklesfield LK. Site-specific differences in bone mineral density in black and white premenopausal South African women. Osteoporos Int. 2012 Feb;23(2):533-42.

Chavassieux P, Seeman E, Delmas PD. Insights into Material and Structural Basis of Bone Fragility from Diseases Associated with Fractures: How Determinants of the Biomechanical Properties of Bone Are Compromised by Disease. Endocr Rev. 2007; 28(2):151-164.

Chen C, Tong N, Ran X, Yang D. The relationship between obesity, intra-abdominal fat area and bone mineral density and bone strength. Sheng Wu Yi Xue Gong Cheng Xue Za Zhi. 2002 Sep;19(3):471-2, 475 
Chen Z, Arendella L, Alackin M, Lawis C, Chlabowski R. Hip bone density predicts breast cancer risk independently of gail score. Cancer 2008; 113(5): 907-915.

Chuengsamarn S, Rattanamongkoulgul S, Suwanwalaikorn S, Wattanasirichaigoon S, Kaufman L. Effects of statins vs. non-statin lipid-lowering therapy on bone formation and bone mineral density biomarkers in patients with hyperlipidemia. Bone. 2010 Apr;46(4):1011-5.

Costa RF. Conhecendo a composição corporal. In:Costa RF (ed). Composição corporal- teoria e prática da avaliação. São Paulo, Manole; 2001p.17-48.

Cui LH, Shin MH, Chung EK, Lee YH, Kweon SS, Park KS, Choi JS. Association between bone mineral densities and serum lipid profiles of pre- and postmenopausal rural women in South Korea. Osteoporos Int 2005 16: 1975-1981

Cui Y, Niziolek PJ, MacDonald BT, Zylstra CR, Alenina N, Robinson DR, Zhong Z, Matthes S, Jacobsen CM, Conlon RA, Brommage R, Liu Q, Mseeh F, Powell DR, Yang QM, Zambrowicz B, Gerrits H, Gossen JA, He X, Bader M, Williams BO, Warman ML, Robling AG. Lrp5 functions in bone to regulate bone mass. Nat Med. 2011 Jun;17(6):684-91.

Cummings SR, Bauer DC. Do statins prevent both cardiovascular disease and fracture? JAMA 2000; 283: 3255-3257.

Datta NS. Osteoporotic fracture and parathyroid hormone. World J Orthop. 2011 Aug 18;2(8):67-74.

Dawson-Hughes B, Harris SS. Calcium intake influences the association of protein intake with rates of bone loss in elderly men and women. Am J Clin Nutr 2002;75:773-9. 
Dawson-Hughes B, Heaney RP, Holick MF, Lips P, Meunier PJ, Vieth R. Estimates of optimal vitamin status. Osteoporosis Int 2005; 16:713-716.

Deluca HF. Overview of general physiologic features and functions of vitamin D. Am J Clin Nutr 2004; 80 (suppl): 1689S-96S

Douchi T, Yamamoto S, Nakamura S, Oki T, Maruta K, Nagata Y. Bone mineral density in postmenopausal women with endometrial cancer. Maturitas. 1999;31(2):165-70

Dvorak MM, Joussineau C, Carter DH, Pisitkun T, Knepper MA, Gamba G, Kemp PJ, Riccardi D Thiazide Diuretics Directly Induce Osteoblast Differentiation and Mineralized Nodule Formation by Interacting with a Sodium Chloride CoTransporter in Bone. J Am Soc Nephrol 2007, 18: 2509-2516.

Emslander HC, Sinaki M, Muhs JM, Chao EY, Wahner HW, Bryant SC, Riggs BL, Eastell R (. Bone mass and muscle strength in female college athletes (runners and swimmers). Mayo Clin Proc. 1998; 73(12):1151-60.

Ettinger B, Pressman A, Sklarin P, Bauer DC, Cauley JA, Cummings SR. Associations between low levels of serum estradiol, bone density, and factures among elderly women: the study of osteoporotic fractures. J Clin Endocrinol Metab $1998 ; 83: 2239-43$.

Felson DT, Zhang Y, Hannan MT, Anderson JJ. Effects of weight and body mass index on bone mineral density in men and women: the Framingham study. JBMR 1993; 8(5):567-73.

Fisberg RM. A qualidade da dieta e seus fatores associados em adultos residents no estado de São Paulo. Tese de Livre-Docência. Faculdade de Saúde Pública da Universidade de São Paulo; 2005. 
Florindo AA, Zerbini CAF, Latorre MRDO, Jaime PC, Tanaka T. Metodology to evaluated the habitual physical activity in men aged 50 years or more. Rev Saúde Pública. 2004;38:307-14.

Frisancho AR. Anthropometric standards for the assessment of growth and nutritional status. Michigan: The University of Michigan Press; 1993.

Fukushima N, Hanada R, Teranishi H, Fukue Y, Tachibana T, Ishikawa H, Takeda S, Takeuchi Y, Fukumoto S, Kangawa K, Nagata K, Kojima M. Ghrelin directly regulates bone formation. JBMR 2005; 20:790-798.

Garrett IR, Gutierrez G, Mundy GR. Statins and boné formation. Curr Pharm Des $2001 ; 7: 715-36$.

Ganry O, Baudoin C, Fardellone P, Peng J,Raverdy N. Bone mass density and risk of breast cancer and survival in older women. European Journal of Epidemiology 19: 785-792, 2004.

Genaro PS, Pereira GA, Pinheiro MM, Szejnfeld VL, Martini LA. Fatores dietéticos, atividade física e composição corporal de mulheres na pós menopausa com osteoporose. Nutrire (SBAN), São Paulo, v 30. p.68-78, 2006.

Ginty F, Rennie, KL, Mils L et al. Positive site-specific association between bone mineral status, fitness, and time spent at high impact activities in 16-18 year-old boys. Bone 2005; 36:101-10.

Grant WB, Holick MF. Benefits and requirements of vitamin D for optimal health: a review. Alten Med Rev 2005;10(2):94-111. 
Gregson CL, Rittweger J, Lazar V, Steel S, Tobias JH. The high bone mass phenotype is characterized by increased trabecular density and reduced endosteal expansion. ASBMR, 2009.

Grenier D, Cooke AL, Lix L, Metge C, Lu H, Leslie WD. Bone mineral density and risk of postmenopausal breast cancer. Breast Cancer Res Treat. 2011 Apr;126(3):679-86. Epub 2010 Sep 14.

Hall TJ, Schaueblin M Hydrochlorothiazide inhibits osteoclastic bone resorption in vitro. Calcif Tissue Int 1994, 55:266-268

Han SL, Wan SL. Effect of teriparatide on bone mineral density and fracture in postmenopausal osteoporosis: meta-analysis of randomised controlled trials. Int J Clin Pract. 2012 Feb;66(2):199-209.

Hardcastle AC, Aucott L, Fraser WD, Reid DM, Macdonald HM. Dietary patterns, bone resorption and bone mineral density in early post-menopausal Scottish women. Eur J Clin Nutr. 2011 Mar;65(3):378-85..

Harvey JA. Re: Are Breast Density and Bone Mineral Density Independent Risk Factors for Breast Cancer? J Natl Cancer Inst. 2005; 97(10):778.

Heaney RP, Recker RR, Saville PD. Menopausal changes in calcium balance performance. J Lab Clin Med 1978; 92: 953-963.

Heaney RP, Recker RR, Stegman MR, Moy AJ. Calcium absorption in women: relationships to calcium intake, estrogen status, and age. JBMR 1989, 4: 469-475.

Heaney RP, Protein intake and the calcium economy. J Am Diet Assoc. 1993 Nov;93(11):1259-60.

Heaney RP. Bone mass, the mechanostat, and ethnic differences [editorial comment]. J Clin Endocrinol Metab 1995;80:2289-90. 
Heaney RP, McCarron DA, Dawson-Hugues B, Oparil S, Berga SL, Stern S, Barr SI, Rosen CJ. Dietary changes favorable affect bone remodeling in older adults. J Am Diet Assoc 1999;99(10):1288-33.

Heaney RP, Holick MF. Why the IOM recommendations for vitamin D are deficient. J Bone Miner Res. 2011 Mar;26(3):455-7.

Hernández JL, Olmos JM, Ramos C, Martínez J, de Juan J, Valero C, Nan D, González-Macías J. Serum lipids and bone metabolism in Spanish men: the Camargo cohort study. Endocr J. 2010;57(1):51-60.

Holick MF. Vitamin D. Em: Sils ME, olson JA, Shike M, Ross AC, editors. Modern nutrition in health and disease. 19ed. Filadélfia: Cippincott. Willinas \& Wilkins p.329-45; 1999.

(a) Holick MF. Functions of vitamin D: importance for prevention of common cancers, type 1 diabetes and heart disease. In: Burckhardt P, Dawson-Hughes B, Heaney RP. Nutritional Aspects of Osteoporosis. Elsevier academic press.USA, 2004 p. $181-201$

(b) Holick MF. Sunlight and vitamin D for bone health and prevention of autoimmune diseases, cancers and cardiovascular disease. Am J Clic Nutr. 2004;80:1678S-88S

Holick MF, Binkley NC, Bischoff-Ferrari HA, Gordon CM, Hanley DA, Heaney RP, Murad MH, Weaver CM; Endocrine Society. Evaluation, treatment, and prevention of vitamin D deficiency: an Endocrine Society clinical practice guideline. J Clin Endocrinol Metab. 2011 Jul;96(7):1911-30. Epub 2011 Jun 6. Erratum in: J Clin Endocrinol Metab. 2011 Dec;96(12):3908. 
Hunt JR, Johnson LK, Roughead ZKF. Dietary protein and calcium interact to influence calcium retention: a controlled feeding study. Am J Clin Nutr 2009;89:1357-65.

Illich-Ernst J, Brownbill RA, Ludemann MA, Fu R. Critical factors for bone health in women across age span: how important is muscle mass? Medscape Womens Health. 2002;7(3):2.

Institute of Medicine (IOM) - Dietary Reference intakes for Calcium, Phosphorus, Magnesium, Vitamina D and Fluoride: Applications in Dietary Assesment. Washington, D.C., National Academy Press, 1997.

International Society for Clinical Densitometry Official Positions (ISCD). www.iscd.org. Updated 2007. Accessed March 2011.

Institute of Medicine (IOM). Dietary Reference Intake for Calcium and Vitamin D. Washington, D.C., National Academy Press, 2011.

Iqbal J, Sun L, Kumar TR, Blair HC, Zaid M. Follicle-stimulating hormone stimulates TNF production from immune cells to enhance osteoblast and osteoclast formation.PNAS 2006; 103 (40): 14925-14930.

Jacobsen SJ, Cooper C, Gottlieb MS, Goldberg J, Yahnke DP, Melton LJ 3rd: Hospitalization with vertebral fracture among the aged: a national population-based incidence among the old and very old: a population-based study of 745,435 cases study, 1986-1989. Epidemiology 1992;3:515-8.

Kamel HK. Low-dose thiazide and bone density. Ann Intern Med 2002; 136 (3): 252-3.

Kanis JA, Passmore R. Calcium supplementation of the diet- I and II. Br Med J 1989;.298: 137-140. 
Kant AK. Dietary patterns and health outcomes. J Am Diet Assoc.2004;104:615-35.

Katsumata S, Masuyama R, Uehara M and Suzuki K. High-phosphorus diet stimulates receptor activator of nuclear factor-kB ligand mRNA expression by increasing parathyroid hormone secretion in rats British Journal of Nutrition 2005; $94,666-674$.

Kawane T, Terashima S, Kurahashi I, Yanagawa T, Yoshida H, Horiuchi N. Atorvastatin enhances bone density in ovariectomized rats given $17 \mathrm{beta}$-estradiol or human parathyroid hormone(1-34). Endocrine. 2004 Jul;24(2):121-9.

Kontogianni MD, Melistas L, Yannakoulia M, Malagaris I, Panagiotakos DB, Yiannakouris N. Association between dietary patterns and indices of bone mass in a sample of Mediterranean women. Nutrition. 2009 Feb;25(2):165-71.

Kuchuk NO, Schoor NMV, Pluijm SM, Chines A, Lips P. Vitamin D Status, Parathyroid Function, Bone Turnover, and BMD in Postmenopausal Women With Osteoporosis: Global Perspective. JBMR 2009; 24(4):693-701.

Kirschner MA, Samojlik E, Drejka M, Szmal E, Schneider G, Ertel N. Androgenestrogen metabolism in women with upper body versus lower body obesity. J Clin Endocrinol Metab 1990;70:473-9.

Kleerekoper M, Nelson DA, Flynn MJ, Pawluszka AS, Jacobsen G, Peterson EL.. Comparison of radiographic absorptiometry with dual-energy $\mathrm{x}$-ray absorptiometry and quantitative computed tomography in normal older white and black women.J Bone Miner Res. 1994 Nov;9(11):1745-9

Koshiyama H, Wada Y, Nakamura Y. Hypercholesterolemia as a possible risk factor for osteopenia in type 2 diabetes mellitus. Arch Inter Med 2001; 161: 1678-1678. 
LaCroix AZ, Wienpahl J, White LR, Wallace RB, Scherr PA, George LK, CornoniHuntley J, Ostfeld AM. Thiazide diuretic agents and the incidence of hip fracture. N Engl J Med 1990; 322:286-290

LaCroix AZ, Ott SM, Ichikawa L, Scholes D, Barlow WE. Low-dose hydrochlorothiazide and preservation of bone mineral density in older adults. A randomized, double-blind, placebocontrolled trial. Ann Intern Med 2000, 133:516526.

Langsetmo L, Hanley DA, Prior JC, Barr SI, Anastassiades T, Towheed T, Goltzman D, Morin S, Poliquin S, et al. Dietary patterns and incident low-trauma fractures in postmenopausal women and men aged 50 y:a population-based cohort study. Am J Clin Nutr. 2011;93:192-9.

Lauderdale DS, Jacobsen SJ, Furner SE, Levy PS, Brody JA, Goldberg J. Hip fracture incidence among elderly Hispanics. Am J Public Health. 1998 Aug;88(8):1245-7.

Lee K. Soft tissue composition and the risk of low bone mineral density: the Fourth Korea National Health And Nutrition Examination Survey (KNHANES IV-3), 2009. Calcif Tissue Int. 2012 Mar;90(3):186-92.

Lekamwasam S, Weerarathna $\mathrm{T}$, Rodrigo $\mathrm{M}$, Arachchi WK, Munidasa D. Association between bone mineral density, lean mass, and fat mass among healthy middle-aged premenopausal women: a cross-sectional study in southern Sri Lanka. J Bone Miner Metab.2009, 27:83-88

Lemann J Jr, Bushinsky DA, Hamm LL. Bone buffering of acid and base in humans. Am J Physiol Renal Physiol 2003, 285:F811-832

Levine DM., Berenson ML, Stephan D. Estatística: Teoria e Aplicações usando Microsoft Excell em Português. Rio de Janeiro: LTC; 2000. 
Lord SR, Ward JA, Williams P, Zivanovic E. The effects of a community exercise program on fracture risk factors in older women. Osteoporos Int 1996, 6: 61-367.

Ma L, Oei L, Jiang L, Estrada K, Chen H, Wang Z, Yu Q, Zillikens MC, Gao X, Rivadeneira F. Association between bone mineral density and type 2 diabetes mellitus: a meta-analysis of observational studies. Eur J Epidemiol. 2012 Mar 27. [Epub ahead of print]

Maccarinelli G, Sibilia V, Torsello A, Raimondo F, Pitto M, Giustina A, Netti C, Cocchi D Ghrelin regulates proliferation and differentiation of osteoblastic cells. J Endocrinol. 2005 Jan;184(1):249-56

McNaughton SA, Wattanapenpaiboon N, Wark JD, Nowson CA. An energy-dense, nutrient-poor dietary pattern is inversely associated with bone health in women. $\mathbf{J}$ Nutr. 2011 Aug;141(8):1516-23.

Majima T, Shimatsu A, Kamatsu Y, Satoh N, Fukao A, Ninomya K, Marsumura T, Natao K. Increased bone turnover in patients with hypercholesterolemia. End J 2008; $55(1): 143-51$.

Makovey J, Chen JS, Hayward C, Williams FM, Sambrook PN Association between serum cholesterol and bone mineral density. Bone. 2009 Feb;44(2):208-13. Epub 2008 Oct 17.

Mallah EM, Hamad MF, Elmanaseer MA, Qinna NA, Idkaidek NM, Arafat TA, Matalka KZ. Plasma concentrations of 25-hydroxyvitamin D among Jordanians: Effect of biological and habitual factors on vitamin D status. BMC Clin Pathol. 2011 Aug 4;11:8.

Mansell JP, Bailey AJ, Yarram SJ. Could bone tissue be a target for luteinizing hormone/chorionic gonadotropin? Mol Cell Endocrinol 2007;169:99-106.

Marcus R. Exercise: moving in the right direction. JBMR 1998, 13:1793-1796. 
Maritz FJ, Conradie MM, Hulley PA, et al. Effect of statins on bone mineral density and bone histomorphometry in rodents. Arterioscler Thromb Vasc Biol 2001;21: $1636-41$.

Martyn-St J M, Carroll S. Effects of different impact exercise modalities on bone mineral density in premenopausal women: a meta-analysis. J Bone Miner Metab. 2010 May;28(3):251-67. Epub 2009 Dec 15.

Matkovic TJ, jelic T, Wrdlaw GM, lich JZ, Goel PK, Wright JK, Andon MB, Smith KT, Heaney RP. Timming of peak bone mass in coucasian females and its implications for prevention of osteoporosis. J Clin Invest. 1994; 93(2):799-808.

Matsudo SM, Matsudo VKR, Neto TLB. Impacto do envelhecimento nas variáveis antropométricas, motoras e metabólicas da aptidão física. Rev Bras Cien Mov 2000; $8(4): 21-32$.

Melhus H, Michaelsson K, Holmberg L, Wolk A, Ljunghall S. Smoking, antioxidant vitamins, and the risk of hip fractures. JBMR 1999;14:129-35

Miller TA, Kokoska ER, Smith GS, Banan A. Role of calcium homeostasis in gastric mucosal injury and protection. Life Sci. 2001 Nov 9;69(25-26):3091-102.

Morgan A, Weiss Jarrett J. Markers of bone turnover across a competitive season in female athletes: a preliminary investigation. J Sports Med Phys Fitness. 2011 Sep;51(3):515-24.

Morii H, Genant HK. Statement on the diagnosis and management of osteoporosis from the Consensus Development Conference at the Second International Conference on Osteoporosis, Osaka 1997. J Bone Miner Metab 1998; 16:206-214.

Mosekilde L, Søgaard CH, McOsker JE, Wronski TJ. PTH has a more pronounced effect on vertebral bone mass and biomechanical competence than antiresorptive 
agents (estrogen and bisphosphonate)--assessed in sexually mature, ovariectomized rats. Bone. 1994 Jul-Aug;15(4):401-8.

Nordin BEC. Calcium and osteoporosis. Nutrition 1997;13:664-86.

Norman AW. From vitamin D to hormone D: fundamentals of the vitamin D endocrine system essential for good health. Am J Clin Nutr 2008; 88(suppl): 491S9S.

Okubo H, Sasaki S, Horiguchi H, Oguma E, Miyamoto K, Hosoi Y, Kim MK, Kayama F Dietary patterns associated with bone mineral density in premenopausal Japanese farmwomen. Am J Clin Nutr. 2006 May;83(5):1185-92.

Olmos JM, Hernández JL, Martínez J, Castillo J, Valero C, Pérez Pajares I, Nan D, González-Macías J. Bone turnover markers and bone mineral density in hypertensive postmenopausal women on treatment. Maturitas. 2010 Apr;65(4):396-402. Epub 2010 Feb 2.

Orozco P. Atherogenic lipid profile and elevated lipoprotein (a) are associated with low bone mineral density in early postmenopausal overweight women. Eur $\mathbf{J}$ Epidemiol 2004; 19:1105-1112.

Orwoll ES, Bevan L, Phipps KR. Determinants of bone mineral density in older men. Osteoporos Int 2000; 11 (10): 815-21.

Ott SM, LaCroix AZ, Scholes D, Ichikawa LE, Wu K. Effects of three years of low-dose thiazides on mineral metabolism in healthy elderly persons. Osteoporos Int $2008 ; 19: 1315-1322$

Parhami F, Jackson SM, Tintut Y, Le V, Balucan JP, Territo M, Demer LL Atherogenic diet and minimally oxidized low density lipoprotein inhibit osteogenic 
and promote adipogenic differentiation of marrow stromal cells. JBMR 1999;14: 2067-2078

Park JH, Song YM, Sung J, Lee K, Kim YS, Kim T, Cho SI. The association between fat and lean mass and bone mineral density: the Healthy Twin Study. Bone. 2012 Apr;50(4):1006-11.

Pasco JA, Kotowicz MA, Henry MJ et al. Statin use, bone mineral density, and fracture risk: Geelong Osteoporosis Study. Arch Intern Med 2002;162 (5): 537-40.

Pereira GA, Genaro OS, Pinheiro MM, Szejnfeld VL, Martini LA. Cálcio dietético estratégias para otimizar o consumo. Rev Bras Reumatol 2009;49(2):164-80

Pereira GA, Genaro PS, Santos LC, Sarkis KS, Pinheiro MM, Szjenfeld VL, Schuch NJ, Martini LA. Validation of a food frequency questionnaire for women with osteoporosis. Journal of Nutrition Health \& Aging. J Nutr Health Aging. 2009 May;13(5):403-7.

Perrien DS, Achenbach SJ, Bledsoe SE, et al. Bone turnover across the menopause transition: correlations with inhibins and follicle-stimulating hormone. J Clin Endocrinol Metab. 2006;91(5):1669-70

Pesonem J, Sirola J, Tuppurainen M, Jurvelin J, Alhava E, Honkaken R, Kröguer H. High bone mineral density among perimenopausal women. Osteoporos Int. 2005, 16:1899-1906.

Pliatsika P, Antoniou A, Alexandrou A, Panoulis C, Kouskouni E, Augoulea A, Dendrinos S, Aravantinos L, Creatsa M, Lambrinoudaki I. Serum lipid levels and bone mineral density in Greek postmenopausal women. Gynecol Endocrinol. 2012 Feb 10. [Epub ahead of print] 
Pinheiro MM, Schuch NJ, Genaro PS, Ciconelli RM, Ferraz MB, Martini LA Nutrient intakes related to osteoporotic fractures in men and women--the Brazilian Osteoporosis Study (BRAZOS) Nutr J. 2009 Jan 29;8:6

Prentice A. Diet, nutrition and the prevention of osteoporosis. Public Health Nutr. 2004 Feb;7(1A):227-43. Review.

Prior JC. FSH and bone important physiology or not? Trends Mol Med 2006;13:1-3.

Reid IR, Ames RW, Orr-Walker BJ, Clearwater JM, Horne AM, Evans MC, Murray MA, McNeil AR, Gamble GD. Hydrochlorothiazide reduces loss of cortical bone in normal postmenopausal women: a randomized controlled trial. Am J Med 2000, 109:362-370.

Reid IR. Relationships among body mass, its components, and bone. Bone. 2002, Nov;31(5):547-55

Reid IR, Cornish J, Baldock P. Nutrition-related peptides and bone homeostasis. JBMR. 2006;21(4):495-500.

Reid IR. Relationships between fat and bone. Osteoporos Int 2008; 19:595-606.

Ricci TA, Heynshfield SB, Pierson Jr RN, Stahl T, Chowalhuney HA, Shaper SA. Moderate energy restriction increased bone resorption in obese postmenopausal women. Am J Clin Nutr 2001;73(2):347-52.

RitterV,ThueringB, SaintMezardP,Luong-NguyenNH,Seltenmeyer Y, Junker U, Fournier B, Susa M, Morvan F Follicle-stimulating hormone does not impact male bone mass in vivo or human male osteoclasts in vitro. Calcif Tissue Int 2008 82:383391

Rizzo M, Di Fede G, Mansueto P. Statins and osteoporosis: myth or reality? Minerva Medica 2004;95:521-7. 
Rizzo M, Rini GB. Statins, Fracture Risk, and Bone Remodeling: What Is True? Am J Med Sci 2006;332(2):55-60.

Saenger AK, Laha TJ, Bremner DE, Sadrzadeh SM. Quantification of serum 25hydroxyvitamin D2 and D3 using HPLC-tandem mass spectrometry and examination of reference intervals for diagnosis of vitamin D deficiency. Am J Clin Pathol 2006;125:914-20.

Samelson GJ, Kiel DP, Broe KE, Zhang Y, Cupples CA, Hannan MT, Wilson PW, Levy D, Williams SA, Vacarrino V. Metacarpal cortical area and risk of coronary heart disease: The Frammingham Study. Am J Epidemiol 2004; 159:589-595.

Saraiva GL, Cendoroglo MS, Ramos LR, Araujo LM, Vieira JG, Maeda SS, Borba VZ, Kunii I, Hayashi LF, Lazaretti-Castro M. Prevalence of vitamin D deficiency, insufficiency and secondary hyperparathyroidism in the elderly inpatients and living in the community of the city of Sao Paulo, Brazil. Arq Bras Endocrinol Metabol. 2007 Apr;51(3):437-42

Schürch MA, Rizzoli R, Slosman D, Vadas L, Vergnaud P, Bonjour JB. Protein supplements increase serum insulin-like growth factor-I levels and attenuate proximal femur bone loss in patients with recent hip fractures. A randomized, double-blind, placebo-controlled trial. Ann Intern Med 1998,128:801-9.

Sendak RA, Sampath TK, McPherson JM. Newly reported roles of thyoidstimulating hormone and follicle-stimulating hormone in bone remodeling. Int Orthop 2007;31:753-7.

Silman AJ, O'Neill TW, Cooper C. Influence of physical activity on vertebral deformity in men and women: results from the European Vertebral Osteoporosis Study. JBMR 1997, 12 (5): 813-819. 
Sowers MR, Finkelstein JS, Ettinger B, Bondarenko I, Neer RM, Cauley JA, Sherman S, Greendale GA. The association of endogenous hormone concentrations and bone mineral density measures in pre- and perimenopausal women of four ethnic groups: SWAN*. Osteoporos Int 2003; 14: 44-52.

Stein EA, Farnier M, Waldstreicher J, et al. Effects of statins on biomarkers of bone metabolism: a randomized trial. Nutr Metab Cardiovasc Dis 2001;11:84-7.

Sun L, Peng Y, Sharrow AC, Iqbal J, Zhang Z, Papachristou DJ, Zaidi S, Zhu L, Yaroslavskiy BB,Zhou H, Zallone A, Sairam MR, Kumar TR, Bo W, Braun J, Landa LC, Schaffler MB,Moonga BS, Blair HC, Zaidi M. FSH Directly Regulates Bone Mass. Cell 2006; 125, 247-260.

Takada H, Washino K, Iwata $\mathrm{H}$. Risk factors for low boné mineral density amog females: the effect of lean body mass. Prev Med 1997; 26:633-8.

Tanaka T, Latorre MR, Jaime PC et al. Risk factors for proximal femur osteoporosis in men aged 50 years or older. Osteoporos Int 2001; 12(11): 942-9.

Tanco LB, Bagger YZ, Christianser C. Low bone density in the hip as a marker of advanced atherosclerosis in elderly women. Calcif Tissue Int 2003;73:15-20.

Tanco LB, Bagger YZ, Nielsem SB, Christianser C. Does serum cholesterol contribute to vertebral bone loss in postmenopausal women? Bone 2003; 32:8-14.

Tanriverdi HA, Barut A, Sarikaya S Statins have additive effects to vertebral bone mineral density in combination with risedronate in hypercholesterolemic postmenopausal women. Eur J Obstet Gynecol Reprod Biol. 2005 May 1;120(1):638

Tintut Y, Parhami F, Tsingotjidou A, Tetradis S, Territo M, Demer LL 8Isoprostaglandin E2 enhances receptor-activated NFkappa B ligand (RANKL)- 
dependent osteoclastic potential of marrow hematopoietic precursors via the cAMP pathway. J Biol Chem 2002; 277: 14221-14226.

Tintut Y, Morony S, Demer LL. Hyperlipidemia promotes osteoclastic potential of bone marrow cells ex vivo. Arterioscler Thromb Vasc Biol 2004; 4: e6-10

Trang H, Cole DE, Rubin LA, Pierratos A, Siu S, Vieth R. Evidence that vitamin D3 increases serum 25-hydroxyvitain D more efficiently than does vitamin D2. Am J Clin Nutr 1998;68:854-8.

Trutschnigg B, Chong C, Habermayerova L, Karelis AD, Komorowski J. Female boxers have high bone mineral density despide low fat mass, high energy expenditure, and high inidence of oligomenorrhea. Appl. Physiol. Nutr. Metab.2008, 33:863-869.

Tucker KL, Chen H, Hannan MT, et al. Bone mineral density and dietary patterns in older adults: the Framingham Osteoporosis Study. Am J Clin Nutr 2002; 76, 245 252

Van der Klift M, de Laet CE, Coebergh JW, Hofman A, Pols HA. Bone mineral density and the risk of breast cancer: the Rotterdam Study. Bone. 2003;32:211-216.

Van Wesenbeeck L, Cleiren E, Gram J, Beals RK, Bénichou O et al. Six novel missense mutations in the LDL receptor-related protein 5 (LRP5) gene in different conditions with an increased bone density. Am J Hum Genet 2003, 72 (3): 763-71.

Vieth R. Why the optimal requirement for vitamin D is probably much higher than what is officially recommended for adults. J Steroid Biochemistry \& Molecular Biology. 2004; 89-90: 575-579

Vieth R. Vitamin D toxicity, policy, and science. J Bone Miner Res. 2007 Dec;22 Suppl 2:V64-8. Review. 
Vural F, Vural B, Yucesoy I, et al. Ovarian aging and one metabolism in menstruating women aged 35-50 years. Maturitas 2005;52:147-53.

Wallace BA, Cumming RG. Systematic review of randomized trials of the effect of exercise on bone mass in pre- and postmenopausal women. Calcif Tissue Int 2000; 67:10-18.

Walsh JB, Lems WF, Karras D, Langdahl BL, Ljunggren O, Fahrleitner-Pammer A, Barrett A, Rajzbaum G, Jakob F, Marin F. Effectiveness of Teriparatide in Women Over 75 Years of Age with Severe Osteoporosis: 36-Month Results from the European Forsteo Observational Study (EFOS). Calcif Tissue Int. 2012 May;90(5):373-83. Epub 2012 Apr 1.

Webb AR. Who, what, where and when-influences on cutaneous vitamin D synthesis. Prog Biophys Mol Biol 2006; 92:17-25.

Willett W, Stampfer M. Total energy intake: implications for epidemiologic analyses. Am J Epidemiol 1986; 124:17-27.

Whyte MP. Searching for gene defects that cause high bone mass. Am J Hum Genet 1997, 60 (6): 1309-11.

World Health Organization (WHO). Assessment of fracture risk and its application to screening for postmenopausal osteoporosis. Report of a WHO Study Group. World Health Organ Tech Rep Ser 1994;843:1-129.

World Health Organization (WHO). Obesity: Preventing and Managing the Global Epidemic. World Health Organization Technical Support Series n894. Geneva: WHO/NUT/NCD, 2000 
Wu LY, Yang TC, Kwo SW, Hsiao CF, Hung YJ, Hsich CH, Tsung HC, Hsieh AT, Chen TW, Chang JB. Correlation between bone mineral density and plasma lipids in Taiwan. Encocr Res 2003; 29:317-325.

Xu H, Watkins BA, Seifert MF. Vitamin E stimulates trabecular bone formation and alters epiphyseal cartilage morphometry. Calcif Tissu Int 1995;57:293-300.

Xu ZR, Wang AH, Wu XP, Zhang H, Sheng ZF, Wu XY, Xie H, Luo XH, Liao EY. Relationship of age-related concentrations of serum FSH and $\mathrm{LH}$ with bone mineral density, prevalence of osteoporosis in native Chinese women. Clin Chim Acta. 2009 Feb;400(1-2):8-13.

Yamagushi T, Sugimoto T, Yano S, Yamagushi M, Sowa H, Chen Q, Chihara K. Plasma lipids and osteoporosis in postmenopausal women. Endocr J 2002; 49: 211217.

Yamaguchi T, Kanazawa I, Yamamoto M, Kurioka S, Yamauchi M, Yano S, Sugimoto T. Associations between components of the metabolic syndrome versus bone mineral density and vertebral fractures in patients with type 2 diabetes. Bone. 2009 Aug;45(2):174-9. 
8. ANEXOS 


\section{Anexo I : TERMO DE CONSENTIMENTO LIVRE E ESCLARECIDO}

Título do Projeto: Fatores Nutricionais, Antropométricos e Hormonais Relacionados à Elevada Densidade Mineral Óssea.

\section{Pesquisadora Responsável: Karin Sedó Sarkis}

Este projeto tem o objetivo de estudar os aspectos relacionados à elevada massa óssea em indivíduos que realizaram densitometria óssea de rotina por qualquer motivo. Para tanto serão necessários realizar os seguintes procedimentos:

- Exame de sangue. A coleta de sangue será feita por uma enfermeira e todo material utilizado é descartável. Serão coletados $20 \mathrm{~mL}$ de sangue.

- Coleta de urina de 24 horas. Esta coleta é feita pela senhora em sua casa. Toda a urina do dia deve ser coletada e guardada em garrafa de água, que deverá ser mantida em geladeira, conforme orientado. Agendaremos um dia para que a senhora leve a garrafa.

- Radiografia da coluna, normalmente conhecido como raio-x de coluna.

- Densitometria óssea. A senhora ficará deitada em uma máquina que irá medir a quantidade de ossos, gorduras e músculos que a senhora possui. Este exame é igual ao exame já realizado anteriormente.

- Responder a três questionários que serão aplicados pela pesquisadora sobre sua alimentação, atividade física e saúde.

Durante a execução do projeto pode ocorrer desconforto pela "picada da agulha" do exame de sangue e possível formação de hematoma (o local da "picada" poderá ficar roxo). Caso tenha qualquer dúvida entre em contato pelos telefones (11) 3061-7762 ou (11) 3061-7859 com Ligia / Karin. Os resultados serão entregues em dia e horário pré-agendados pela pesquisadora.

A senhora tem o direito de:

1. receber resposta a qualquer pergunta $\mathrm{e}$ esclarecimento sobre os 
procedimentos, riscos, benefícios e outros relacionados à pesquisa;

2. retirar o consentimento a qualquer momento e deixar de participar do estudo;

3. não ser identificado e ser mantido o caráter confidencial das informações relacionadas à privacidade.

4. procurar esclarecimentos com o Comitê de Ética em Pesquisa da Faculdade de Saúde Pública da Universidade de São Paulo, no telefone 11 3061-7779 ou Av. Dr. Arnaldo, 715 - Cerqueira César, São Paulo - SP, em caso de dúvidas ou notificação de acontecimentos não previstos.

Declaro estar ciente do exposto e desejo participar do projeto.

São Paulo, de de 


\section{Anexo II: INVESTIGAÇÃO DE FATORES DE RISCO PARA AVALIAÇÃo DA MASSA ÓSSEA}

1- Identificação:

Data:

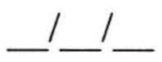

Nome:

Data Nasc.

I I Idade

Raça:

RGH:

Fone:

2- Dados antropométricos:

Peso (kg):

Altura (m):

IMC:

Peso aos 25 anos de idade

(kg):

3- Dados Ginecológicos:

- Idade da primeira menstruação? anos

- Você já usou pílula anticoncepcional por mais de 3 meses ? $\quad \operatorname{sim} \square \quad$ não $\square$ não sei $\sqsubset$

- Você já ficou algum período em sua vida sem menstruar antes da menopausa (exceto, se
gravidez) ?
$\operatorname{sim} \square$
não
não sei $\sqsubset$

- Idade da última menstruação ? anos

Número de filhos:

- Você fez cirurgia para retirar o útero ? $\operatorname{sim} \sqsubset \quad$ não $\square \quad$ não sei $\sqsubset \quad$ Idade (anos)

E, para retirar os ovários (um ou os dois)? $\operatorname{sim} \square$ não $\square$ não sei $\square$ Idade (anos) 
- Você fez reposição hormonal após a menopausa ? $\quad \operatorname{sim} \sqsubset \quad$ não $\square$ não sei $\sqsubset$

- Se sim, quando iniciado, o período foi superior a 1 ano ? $\quad \operatorname{sim} \square \quad$ não $\square$ não sei

- Você amamentou ? $\quad \operatorname{sim} \sqsubset \quad$ não $\square \quad$ não sei $\sqsubset$

- Se sim, quantas crianças você amamentou por mais que 3 meses ?

4- História Mórbida Pessoal:

HAS $\square \quad$ DM $\square \quad$ Fibromialgia $\square \quad$ Neoplasia $\square \quad \_$Doença GI $\sqsubset$

Doença Renal $\square$

Doença CV $\square$

DRAI $\square$

Doença Endócrina $\square$

Hepatite $\square$

- Você já usou as seguintes medicações:

Estatinas $\square$ Diuréticos de alça $\square$ ou tiazídicos $\square$ Hormônios Anabolizantes $\square$ PTH ᄃ

Bisfosfonatos $\square$ SERMS $\square$ Suplemento de Cálcio $\sqsubset$ ou vitamina D $\square$ Calcitonina $\square$ Corticosteróides

5- Dados familiares :

- Em sua família (pai, mãe, irmãos) existe história de fratura de qualquer osso após os 50 anos de idade? $\quad \operatorname{sim} \sqsubset \quad$ não $\sqsubset \quad$ não sei $\sqsubset$

- Em sua família (pai, mãe e irmãos) existe alguém com osteoporose ?sim $\square$ não $\square$ não sei $\sqsubset$

- Em sua família (pai, mãe e irmãos) existe alguém com obesidade ? $\quad$ sim $\square$ não $\square$ não sei $\sqsubset$ 
6- História Pessoal:

- Você já teve alguma fratura ? $\quad \operatorname{sim} \square \quad$ não $\square \quad$ não sei $\square$

- Se sim, em qual sítio esquelético, com que idade e qual foi o tipo de trauma ?

- Você já fez dieta para perder peso ? $\operatorname{sim} \square$ não $\square$ não sei $\square \quad$ Quanto foi a perda ? $\mathrm{kg}$

- Você já fez dieta para ganhar peso ? $\operatorname{sim} \square \quad$ não $\square$ não sei $\square$ Quão foi o ganho ?

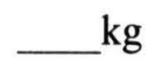

- Você foi considerado obeso na infância ou adolescência ? $\operatorname{sim} \square \quad$ não $\square \quad$ não sei $\sqsubset$

7- Hábitos:

- Com que freqüência você bebeu no último ano ?

diariamente $\square \quad 5-6 \mathrm{~d} / \mathrm{sem} \square \quad 3-4 \mathrm{~d} / \mathrm{sem} \square \quad 1-2 \mathrm{~d} / \mathrm{sem} \square<1 \mathrm{~d} / \mathrm{sem} \square$ nunca $\sqsubset$

- Tipo de bebida: destilados $\sqsubset$ fermentados $\square$

- Você já ficou acamado por um período superior a 2 meses ? sim $\square$ não $\square$ não sei ᄃ

- Você fumou cigarro ou usou outras formas de fumo (cachimbo ou charuto)? atualmente $\square$ no passado $\square$ nunca $\square$

- Idade de início ? anos; Se parou, com que idade ? anos; $\mathrm{N}^{\circ}$ de cigarros/dia? 


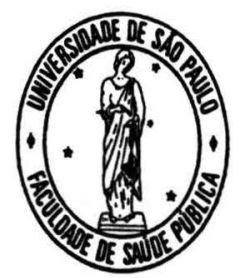

\author{
UNIVERSIDADE DE SÃO PAULO \\ FACULDADE DE SAÚDE PÚBLICA \\ DEPARTAMENTO DE NUTRIÇÃO
}

Questionário de Frequência de Alimentos

Nome:

Data

Peso:

Altura:

Data nasc.

- idade

anos

Início da doença:

Iníclo da menopausa:

Peso anterior:

Suplementos: Você toma algum suplemento vitamínico?

Tipo: Freqüência:

Você mudou seus hábitos alimentares recentemente por algum motivo?
(1) não
(4) sim, devido a osteoporose
(2) sim, para perda de peso
(5) sim, para ganhar peso
(3) sim, por orientação médica
(6) outro motivo:

\begin{tabular}{|l|l|l|l|l|l|l|l|l|l|}
\hline Alimento & Nunca & $\begin{array}{l}\text { Menos } \\
\text { De Ix } \\
\text { mês }\end{array}$ & $\begin{array}{l}1 \mathrm{a} \\
3 \mathrm{X} \\
\mathrm{més}\end{array}$ & $\begin{array}{l}1 \mathrm{x} \\
\text { por } \\
\text { sem }\end{array}$ & $\begin{array}{l}2 \mathrm{a} 4 \mathrm{x} \\
\text { sem }\end{array}$ & $\begin{array}{l}1 \mathrm{x} \\
\text { dia }\end{array}$ & $\begin{array}{l}2 \text { ou } \\
\text { mais } \\
\mathrm{x} \text { dia }\end{array}$ & Porção Média & Sua Porção \\
\hline Leite e derivados & & & & & & & & & \\
\hline $\begin{array}{l}\text { Leite Tipo: } \\
\text { ()integral () desnat } \\
\text { () semidesnat }\end{array}$ & & & & & & & & $\begin{array}{l}1 \text { copo } \\
(150 \mathrm{ml})\end{array}$ & P M G E \\
\hline logurte ou coalhada & & & & & & & & 1 copo (200ml) & P M G E \\
\hline Queijo Minas - Ricota & & & & & & & & $\begin{array}{l}1 \text { fatia pequena } \\
(20 \mathrm{~g})\end{array}$ & P M G E \\
\hline $\begin{array}{l}\text { Requeijão } \\
\text { () regular () light }\end{array}$ & & & & & & & & 1 colher sopa (20g) & P M G E \\
\hline Queijos Amarelos & & & & & & & & $\begin{array}{l}2 \text { fatias médias } \\
(30 \mathrm{~g})\end{array}$ & P M G E \\
\hline Queijo Ralado & & & & & & & & 1 colher sopa (15g) & P M G E \\
\hline Manteiga & & & & & & & & 2 ponta faca (5 g) & P M G E \\
\hline Margarina & & & & & & & & 2 ponta faca (5g) & P M G E \\
\hline Sorvete Cremoso & & & & & & & & 2 bola (120g) & P M G E \\
\hline
\end{tabular}




\begin{tabular}{|c|c|c|c|c|c|c|c|c|c|}
\hline Alimento & Nunca & $\begin{array}{l}\text { Menos } \\
\text { De 1x } \\
\text { mês }\end{array}$ & $\begin{array}{l}1 \mathrm{a} \\
3 \mathrm{X} \\
\text { mês }\end{array}$ & $\begin{array}{l}1 \mathrm{x} \\
\text { por } \\
\text { sem }\end{array}$ & $\begin{array}{l}2 a \\
4 x \\
\text { sem }\end{array}$ & $\begin{array}{l}1 x \\
\text { dia }\end{array}$ & $\begin{array}{l}2 \text { ou } \\
\text { mais } \\
x \text { dia }\end{array}$ & Porção Média & $\begin{array}{l}\text { Sua } \\
\text { Porção }\end{array}$ \\
\hline \multicolumn{10}{|l|}{ Frutas/sucos } \\
\hline Banana & & & & & & & & 1 uni média $(60 \mathrm{~g})$ & PMGE \\
\hline Uva & & & & & & & & 1 cacho & PMGE \\
\hline Laranja/mexerica & & & & & & & & 2 uni médias $(180 \mathrm{~g})$ & PMGE \\
\hline Mamão & & & & & & & & $\begin{array}{l}1 \text { fatia gde } 1 / 2 \text { papaya } \\
(180 \mathrm{~g})\end{array}$ & P M G E \\
\hline Maça/Pera & & & & & & & & 1 uni média $(130 \mathrm{~g})$ & P M G E \\
\hline Melânica /Melão & & & & & & & & 1 fatia média $(150 \mathrm{~g})$ & P M GE \\
\hline Manga & & & & & & & & 1 uni gde $(220 \mathrm{~g})$ & PMGE \\
\hline Abacaxi & & & & & & & & 2,5 fat médias $(260 \mathrm{~g})$ & PMGE \\
\hline Goiaba/Caqui & & & & & & & & 1 uni peq $(60 \mathrm{~g})$ & P M GE \\
\hline $\begin{array}{l}\text { Suco Laranja } \\
\text { Natural }\end{array}$ & & & & & & & & 1 copo $(200 \mathrm{ml})$ & P M G E \\
\hline $\begin{array}{l}\text { Suco } \\
\text { Caju/Maracujá }\end{array}$ & & & & & & & & 1 copo $(200 \mathrm{ml})$ & P M G E \\
\hline Outros & & & & & & & & & \\
\hline
\end{tabular}

\begin{tabular}{|l|l|l|l|l|l|l|l|l|l|}
\hline Alimento & Nunca & $\begin{array}{l}\text { Menos } \\
\text { De } 1 \mathrm{x} \\
\mathrm{més}\end{array}$ & $\begin{array}{l}1 \mathrm{a} 3 \mathrm{X} \\
\mathrm{mês}\end{array}$ & $\begin{array}{l}1 \mathrm{x} \text { por } \\
\mathrm{sem}\end{array}$ & $\begin{array}{l}2 \mathrm{a} 4 \mathrm{x} \\
\mathrm{sem}\end{array}$ & $\begin{array}{l}1 \mathrm{x} \\
\mathrm{dia}\end{array}$ & $\begin{array}{l}2 \text { ou } \\
\text { mais } \\
\mathrm{x} \text { dia }\end{array}$ & Porção Média & $\begin{array}{l}\text { Sua } \\
\text { Porção }\end{array}$ \\
\hline Vegetais & & & & & & & & & \\
\hline $\begin{array}{l}\text { Alface } \\
\text { Acelga }\end{array}$ & & & & & & & & $\begin{array}{l}3 \text { folhas médias } \\
(30 \mathrm{~g})\end{array}$ & P M G E \\
\hline Tomate & & & & & & & & 1 un peque -4 fatias & P M G E \\
\hline $\begin{array}{l}\text { Couve } \\
\text { Espinafre coz }\end{array}$ & & & & & & & & 3 colh sopa (60g) & P M G E \\
\hline $\begin{array}{l}\text { Beterraba } \\
\text { Cenoura } \\
\text { crua/coz }\end{array}$ & & & & & & & & $\begin{array}{l}4 \text { fatias } 2,5 \text { col sopa } \\
(50 \mathrm{~g})\end{array}$ & P M G E \\
\hline $\begin{array}{l}\text { Pepino } \\
\text { Pimentão }\end{array}$ & & & & & & & & 2 col sopa (20g) & P M G E \\
\hline Berinjela & & & & & & & & 2 col sopa & P M G E \\
\hline $\begin{array}{l}\text { Brocoli } \\
\text { Couve Flor }\end{array}$ & & & & & & & & 2 ramos médios & P M G E \\
\hline $\begin{array}{l}\text { Sopa de } \\
\text { legumes }\end{array}$ & & & & & & & & $\begin{array}{l}2 \text { conchas médias } \\
(260 \mathrm{ml})\end{array}$ & P M G E \\
\hline Outros & & & & & & & & & \\
\hline
\end{tabular}

\begin{tabular}{|c|c|c|c|c|c|c|c|c|c|}
\hline Alimento & Nunca & $\begin{array}{l}\text { Menos } \\
\text { De Ix } \\
\text { mês }\end{array}$ & $\begin{array}{l}1 \mathrm{a} \\
3 \mathrm{X} \\
\text { mês } \\
\end{array}$ & $\begin{array}{l}\text { Ix } \\
\text { por } \\
\text { sem }\end{array}$ & $\begin{array}{l}2 \mathrm{a} \\
4 \mathrm{x} \\
\text { sem }\end{array}$ & $\begin{array}{l}1 \mathrm{x} \\
\text { dia }\end{array}$ & $\begin{array}{l}2 \text { ou } \\
\text { mais } \\
x \text { dia } \\
\end{array}$ & Porção Média & $\begin{array}{l}\text { Sua } \\
\text { Porção }\end{array}$ \\
\hline \multicolumn{10}{|l|}{ Leguminosas } \\
\hline Feijão & & & & & & & & 1 concha média $(90 \mathrm{~g})$ & PMGE \\
\hline Soja & & & & & & & & 2 colheres sopa & PMGE \\
\hline Ervilha, lentilha & & & & & & & & 2 col sopa $(60 \mathrm{~g})$ & PMGE \\
\hline Outros & & & & & & & & & PMGE \\
\hline
\end{tabular}




\begin{tabular}{|l|l|l|l|l|l|l|l|l|l|}
\hline & Nunca & $\begin{array}{l}\text { Menos } \\
\text { De 1x } \\
\text { mês }\end{array}$ & $\begin{array}{l}1 \mathrm{a} \\
3 \mathrm{x} \\
\text { mês }\end{array}$ & $\begin{array}{l}1 \mathrm{x} \\
\text { por } \\
\text { sem }\end{array}$ & $\begin{array}{l}2 \mathrm{a} \\
4 \mathrm{x} \\
\text { sem }\end{array}$ & $\begin{array}{l}1 \mathrm{x} \\
\text { dia }\end{array}$ & $\begin{array}{l}2 \text { ou } \\
\text { mais } \\
\mathrm{x} \text { dia }\end{array}$ & Porção Média & $\begin{array}{l}\text { Sua } \\
\text { Porção }\end{array}$ \\
\hline Carnes/ Ovos & & & & & & & & & \\
\hline $\begin{array}{l}\text { Carne Boi coz, } \\
\text { assada, grelhada }\end{array}$ & & & & & & & & $\begin{array}{l}1 \text { bife médio, 3 } \\
\text { pedaços (100g) }\end{array}$ & P M G E \\
\hline Churrasco & & & & & & & & 3 pedaços (100g) & P M G E \\
\hline $\begin{array}{l}\text { Frango, coz, } \\
\text { assado, frito }\end{array}$ & & & & & & & & $\begin{array}{l}3-4 \text { pedaços } \\
\text { médiso (120g) }\end{array}$ & P M G E \\
\hline $\begin{array}{l}\text { Peixe coz, assado, } \\
\text { grelhado, frito }\end{array}$ & & & & & & & & $\begin{array}{l}1 \text { posta, 1 pedaço } \\
\text { grande (100- } \\
120 \mathrm{~g})\end{array}$ & P M E \\
\hline $\begin{array}{l}\text { Lingüiça, salsicha, } \\
\text { presunto, etc.. }\end{array}$ & & & & & & & & $\begin{array}{l}1 \text { unidade, 1 } \\
\text { gomo ou 2 fatias } \\
(40 \mathrm{~g})\end{array}$ & P M G E \\
\hline Ovos (coz, frito) & & & & & & & & $\begin{array}{l}1 \text { unidade média } \\
(60 \mathrm{~g})\end{array}$ & P M G E \\
\hline Outros & & & & & & & & & \\
\hline
\end{tabular}

\begin{tabular}{|l|l|l|l|l|l|l|l|l|l|}
\hline Alimento & Nunca & $\begin{array}{l}\text { Menos } \\
\mathrm{De} 1 \mathrm{x} \\
\mathrm{mês}\end{array}$ & $\begin{array}{l}1 \mathrm{a} \\
3 \mathrm{X} \\
\mathrm{mês}\end{array}$ & $\begin{array}{l}1 \mathrm{x} \\
\mathrm{por} \\
\mathrm{sem}\end{array}$ & $\begin{array}{l}2 \mathrm{a} 4 \mathrm{x} \\
\text { sem }\end{array}$ & $\begin{array}{l}1 \mathrm{x} \\
\mathrm{dia}\end{array}$ & $\begin{array}{l}2 \text { ou } \\
\text { mais } \\
\mathrm{x} \text { dia }\end{array}$ & Porção Média & $\begin{array}{l}\text { Sua } \\
\text { Porção }\end{array}$ \\
\hline Pães e Biscoitos & & & & & & & & \\
\hline $\begin{array}{l}\text { Pão francês, forma, } \\
\text { integral, caseiro, } \\
\text { doce }\end{array}$ & & & & & & & & $\begin{array}{l}1 \text { unidade ou (2 } \\
\text { fatias 50g) }\end{array}$ & P M G E \\
\hline $\begin{array}{l}\text { Biscoito salgado } \\
\text { ou doce sem } \\
\text { recheio }\end{array}$ & & & & & & & & $\begin{array}{l}5 \mathrm{a} 6 \text { unidades } \\
(30 \mathrm{~g})\end{array}$ & P M G E \\
\hline $\begin{array}{l}\text { Biscoito doce com } \\
\text { recheio }\end{array}$ & & & & & & & & 3 unidades (40g) & P M G E \\
\hline \begin{tabular}{l} 
Bolos e tortas \\
\hline Outros
\end{tabular} & & & & & & & $\begin{array}{l}1 \text { fatia média } \\
(50 \mathrm{~g})\end{array}$ & P M G E \\
\hline
\end{tabular}




\begin{tabular}{|c|c|c|c|c|c|c|c|c|c|}
\hline Alimento & Nunca & $\begin{array}{l}\text { Menos } \\
\text { De } 1 \mathrm{x} \\
\text { mês }\end{array}$ & $\begin{array}{l}1 \mathrm{a} \\
3 \mathrm{X} \\
\mathrm{mês} \\
\end{array}$ & $\begin{array}{l}\mathrm{Ix} \\
\text { por } \\
\text { sem } \\
\end{array}$ & $\begin{array}{l}2 a \\
4 x \\
\text { sem }\end{array}$ & $\begin{array}{l}1 \mathrm{x} \\
\mathrm{dia}\end{array}$ & $\begin{array}{l}2 \text { ou } \\
\text { mais } \\
x \text { dia }\end{array}$ & Porção Média & $\begin{array}{l}\text { Sua } \\
\text { Porção }\end{array}$ \\
\hline \multicolumn{10}{|l|}{ Arroz/Massas } \\
\hline $\begin{array}{l}\text { Arroz coz c óleo e } \\
\text { temp }\end{array}$ & & & & & & & & $\begin{array}{l}\text { 3-4 colheres sopa } \\
(90 \mathrm{~g}))\end{array}$ & PMGE \\
\hline $\begin{array}{l}\text { Batata/Mandioca coz, } \\
\text { frita, assada }\end{array}$ & & & & & & & & $\begin{array}{l}\text { 2colheres, 2- } \\
\text { 3pedaços }(50-180 \mathrm{~g})\end{array}$ & PMGE \\
\hline Salada de maionese & & & & & & & & $\begin{array}{l}3 \text { colheres de sopa } \\
(90 \mathrm{~g})\end{array}$ & PMGE \\
\hline Batata doce & & & & & & & & $\begin{array}{l}3 \text { ped médios ou } 1 \\
\text { unid média }(90 \mathrm{~g})\end{array}$ & PMGE \\
\hline Abóbora & & & & & & & & $\begin{array}{l}3 \text { pedaços médios } \\
(90 \mathrm{~g})\end{array}$ & PMGE \\
\hline Farofa/ fa mandioca & & & & & & & & $\begin{array}{l}2 \text { colheres de sopa } \\
(30 \mathrm{~g})\end{array}$ & PMGE \\
\hline Cuscuz/pirão/canjica & & & & & & & & 1 ped médio $(130 \mathrm{~g})$ & PMGE \\
\hline Macarronada/lasanha & & & & & & & & 1 esc $1 / 2$ prato $(75 g)$ & P M GE \\
\hline $\begin{array}{l}\text { Pastelarias (empada, } \\
\text { coxinha, pastel, etc) }\end{array}$ & & & & & & & & $\begin{array}{l}1 \text { unidade }-1 \text { pedaço } \\
\text { médio }(60 \mathrm{~g})\end{array}$ & P M GE \\
\hline Outros & & & & & & & & & \\
\hline
\end{tabular}

\begin{tabular}{|l|l|l|l|l|l|l|l|l|l|}
\hline Alimento & Nunca & $\begin{array}{l}\text { Menos } \\
\text { De } 1 \mathrm{x} \\
\mathrm{mês}\end{array}$ & $\begin{array}{l}1 \mathrm{a} \\
3 \mathrm{X} \\
\mathrm{mês}\end{array}$ & $\begin{array}{l}1 \mathrm{x} \\
\mathrm{por} \\
\text { sem }\end{array}$ & $\begin{array}{l}2 \mathrm{a} \\
4 \mathrm{x} \\
\mathrm{sem}\end{array}$ & $\begin{array}{l}1 \mathrm{x} \\
\text { dia }\end{array}$ & $\begin{array}{l}2 \text { ou } \\
\text { mais } \\
\mathrm{x} \text { dia }\end{array}$ & Porção Média & Sua Porção \\
\hline $\begin{array}{l}\text { Doces/ } \\
\text { sobremesas }\end{array}$ & & & & & & & & & \\
\hline Doce de frutas & & & & & & & & $\begin{array}{l}1 \text { pedaço médio } \\
(60 \mathrm{~g})\end{array}$ & P M G E \\
\hline $\begin{array}{l}\text { Chocolates, } \\
\text { bombom. } \\
\text { Brigadeiros }\end{array}$ & & & & & & & & $\begin{array}{l}2 \text { unidades ou 1 } \\
\text { barra (30g) }\end{array}$ & P M G E \\
\hline $\begin{array}{l}\text { Acúcar (café, chá } \\
\text { etc...) }\end{array}$ & & & & & & & & 3 cl cha (12g) & P M G E \\
\hline Outros doces & & & & & & & & & P M G E \\
\hline
\end{tabular}

\begin{tabular}{|c|c|c|c|c|c|c|c|c|c|}
\hline Alimento & Nunca & $\begin{array}{l}\text { Menos } \\
\text { De } 1 \mathrm{x} \\
\text { mês }\end{array}$ & $\begin{array}{l}1 \mathrm{a} \\
3 \mathrm{X} \\
\text { mês }\end{array}$ & $\begin{array}{l}1 \mathrm{x} \\
\text { por } \\
\text { sem }\end{array}$ & $\begin{array}{l}2 a \\
4 x \\
\text { sem }\end{array}$ & $\begin{array}{l}1 \mathrm{x} \\
\mathrm{dia}\end{array}$ & $\begin{array}{l}2 \text { ou } \\
\text { mais } \\
x \text { dia }\end{array}$ & Porção Média & Sua Porção \\
\hline \multicolumn{10}{|l|}{ Bebidas } \\
\hline Café & & & & & & & & $\begin{array}{l}1 \text { xícara gde (200 } \\
\mathrm{ml})\end{array}$ & P M GE \\
\hline Chá & & & & & & & & $\begin{array}{l}1 \text { xícara gde (200 } \\
\mathrm{ml}\end{array}$ & P M G E \\
\hline $\begin{array}{l}\text { Refrigerantes, } \\
\text { regular ou diet }\end{array}$ & & & & & & & & 1 copo & P M GE \\
\hline Cerveja/Vinho & & & & & & & & $\begin{array}{l}1 \text { lata }(350 \mathrm{ml}) \\
\text { 2cálices }(120 \mathrm{ml})\end{array}$ & PMGE \\
\hline $\begin{array}{l}\text { Pinga, whisky, } \\
\text { vodka }\end{array}$ & & & & & & & & 2 doses $(60 \mathrm{ml})$ & PMGE \\
\hline & & & & & & & & & \\
\hline
\end{tabular}




\begin{tabular}{|l|l|l|l|l|l|l|l|l|l|}
\hline Alimento & Nunca & $\begin{array}{l}\text { Menos } \\
\text { De lx } \\
\text { mês }\end{array}$ & $\begin{array}{l}\text { la } \\
3 \mathrm{X} \\
\mathrm{més}\end{array}$ & $\begin{array}{l}\mathrm{lx} \\
\text { por } \\
\text { sem }\end{array}$ & $\begin{array}{l}2 \mathrm{a} \\
4 \mathrm{x} \\
\text { sem }\end{array}$ & $\begin{array}{l}1 \mathrm{x} \\
\text { dia }\end{array}$ & $\begin{array}{l}2 \text { ou } \\
\text { mais } \\
\mathrm{x} \text { dia }\end{array}$ & Porção Média & Sua Porção \\
\hline $\begin{array}{l}\text { Molhos/ } \\
\text { oleos }\end{array}$ & & & & & & & & & \\
\hline $\begin{array}{l}\text { Oleo (soja, } \\
\text { milho, etc) }\end{array}$ & & & & & & & & $\begin{array}{l}3 \text { col sobremesa } \\
(15 \mathrm{~g})\end{array}$ & P M G E \\
\hline Azeite & & & & & & & & 2 fios (10ml) & P M G E \\
\hline $\begin{array}{l}\text { Katchup/ } \\
\text { mostarda }\end{array}$ & & & & & & & & 1 col sopa (10g) & P M G E \\
\hline Maionese & & & & & & & & 1 col sopa (15g) & P M G E \\
\hline
\end{tabular}


Anexo IV: AVALIAÇÃo DA ATIVIDADE FÍSICA

\begin{tabular}{|c|l|l|l|}
\hline & Até os 18 anos & Dos 19 aos 35 anos & Após os 35 anos \\
\hline Tipo & & & \\
\hline $\begin{array}{c}\text { Freqüência (h/ } \\
\text { semana) }\end{array}$ & & & \\
\hline Duração & & & \\
\hline
\end{tabular}

1) Qual tem sido sua principal ocupação?

$1 \quad 3$

5

2) No trabalho, eu sento: nunca/raro/algumas vezes/freqüente/sempre $1 \quad 2 \quad 3 \quad 4 \quad 5$

3) No trabalho, eu fico em pé: nunca/raro/algumas vezes/freqüente/sempre $\begin{array}{lllll}1 & 2 & 3 & 4 & 5\end{array}$

4) No trabalho, eu ando: nunca/raro/algumas vezes/freqüente/sempre $\begin{array}{lllll}1 & 2 & 3 & 4 & 5\end{array}$

5) No trabalho, eu carrego carga pesada: nunca/raro/algumas vezes/freqüente/sempre

$\begin{array}{lllll}1 & 2 & 3 & 4 & 5\end{array}$

6) Após o trabalho, eu carrego carga pesada:

Muito freqüente/freqüente/algumas vezes/raro/nunca

$\begin{array}{lll}3 & 2 & 1\end{array}$

7) No trabalho, eu suo: muito freqüente/freqüente/algumas vezes/raro/nunca

$\begin{array}{llll}4 & 3 & 2 & 1\end{array}$

8) Em comparação com outros da minha idade, eu penso que meu trabalho é fisicamente:

Muito mais pesado/mais pesado/tão pesado quanto/mais leve/muito mais leve 5 $\begin{array}{llll}4 & 3 & 2 & 1\end{array}$

9) Você pratica ou praticou esporte ou exercício físico nos últimos 12 meses: $\mathrm{Sim} /$ Não 
10) Qual esporte ou exercício você pratica ou praticou mais freqüentemente?

- quantas horas por semana? $\quad<1 \quad 1<2 \quad 2<3 \quad 3-4 \quad>4$

- quantos meses por ano? $\quad<1 \quad 1-3 \quad 4-6 \quad 7-9 \quad>9$

Se você faz ou fez um segundo esporte ou exercício físico, qual o tipo? $\quad \begin{array}{lll}1 & 3\end{array}$ 5

- quantas horas por semana?

$$
\begin{array}{llllll}
\text { - quantas horas por semana? } & <1 & 1<2 & 2<3 & 3-4 & >4 \\
\text { - quantos meses por ano? } & <1 & 1-3 & 4-6 & 7-9 & >9
\end{array}
$$

10) Em comparação com outros da minha idade eu penso que minha atividade física durante as horas de lazer é: Muito maior/maior/a mesma/menor/muito menor $\begin{array}{lllll}5 & 4 & 3 & 2 & 1\end{array}$

11) Durante horas de lazer eu suo: muito freqüente/freqüente/algumas vezes/raro/nunca $5 \begin{array}{lllll}4 & 3 & 2 & 1\end{array}$

12) Durante as horas de lazer eu pratico esporte ou exercício físico:

$\begin{array}{lllllll}\text { Nunca/raro/algumas vezes/freqüente/muito freqüente } & & 1 & 2 & 3 & 4\end{array}$ 5

13) Durante as horas de lazer eu vejo televisão:

$\begin{array}{lllllll}\text { Nunca/raro/algumas vezes/freqüente/muito freqüente } & & 1 & 2 & 3 & 4\end{array}$ 5

14) Durante horas de lazer eu ando: nunca/raro/algumas vezes/freqüente/muito freqüente 12345

15) Durante as horas de lazer eu ando de bicicleta:

Nunca/raro/algumas vezes/freqüente/muito freqüente $\quad \begin{array}{lllll}1 & 2 & 3 & 4\end{array}$ 5

16) Durante quantos minutos por dia você anda a pé ou de bicicleta indo e voltando do trabalho, escola ou compras? $<5 / 5-15 / 16-30 / 31-45 />45$ 


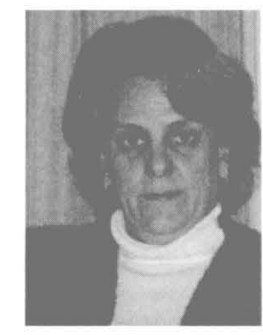

\section{Lígia Araújo Martini}

Bolsista de Produtividade em Pesquisa do CNPq - Nivel 2

Graduação em Nutricao pelo Centro Universitário São Camilo - Campus Pompeia (1989) mestrado em Nutrição pela Universidade Federal de São Paulo (1993) e doutorado em Nutrição pela Universidade Federal de São Paulo (1998). Realizou Pós-Doutorado no USDA Jean Maye Human Nutrition Research Center on Aging at Tufts Univeristy - Boston MA. Foi Pesquisado Associado nivel 3 no Mineral Bioavailability Laboratory da mesma instituição entre 2000 e 2001 Atualmente é Professor Associado da Universidade de São Paulo. É Coordenadora do Programa de Pós-Graduação em Nutrição em Saúde Pública da USP (inicio em 2010). Faz parte do Nucleo de Pesquias em Alimentos e Nutrição - NAPAN do USP. Atua como edito parteribule do Nutition Reviews e revisor cientifico da Clinical Nuttition Anals of Nutrition and entre outras. Tem experiência na área de Nutrição, com ênfase em Nutrição e Metabolismo, atuando principalmente nos seguintes temas: metabolismo mineral ósseo, vitamina $D$, sindrome metabólica, macadores bioquímicos da ingestão alimentar e da composição copora

(Texto informado pelo autor)

Última atualização do curriculo em 14/06/2012

Endereço para acessar este $\mathrm{CV}$

http://lattes.cnpq.br/1709520521624949

Certificado

$14 / 06 / 12$

\begin{tabular}{|c|c|}
\hline Dados pessoais & \\
\hline Nome & Ligia Araújo Martini \\
\hline $\begin{array}{r}\text { Nome em citações } \\
\text { bibliográficas }\end{array}$ & MARTINI, LA;Martini, L. A.;Martini, Ligia A.;Martini, Ligia Araújo \\
\hline Sexo & Feminino \\
\hline Endereço profissional & $\begin{array}{l}\text { Universidade de São Paulo, Faculdade de Saúde Pública, Departamento de Nutrição. } \\
\text { Av: Dr. Arnaldo, } 715 \\
01246-904 \text { - Sao Paulo, SP - Brasil } \\
\text { Telefone: (11) } 30617859 \text { Fax: (11) } 30617130\end{array}$ \\
\hline
\end{tabular}

\section{Formação acadêmica/Titulação}

2008 Livre-docência

Universidade de São Paulo, USP, Brasil.

Titulo: Metabolismo ósseo: uma abordagem nutricional, Ano de obtenção: 2008.

Palavras-chave: Avaliação Nutricional; densidade mineral ossea; doença óssea.

1998 - 2001 Pós-Doutorado

Jean Mayer Human Nutrition Research Center On Aging At Tufts Univeristy.

Bolsista do(a): Fundação de Amparo à Pesquisa do Estado de São Paulo ,FAPESP .Brasil .

Grande área: Ciências da Saúde / Area: Nutrição / Subárea: Bioquimica da Nutrição / Especialidade:

Biodisponibilidade de Nutrientes.

Grande área: Ciências da Saúde / Área: Nutrição / Subárea: Bioquímica da Nutrição / Especialidade: Interaçao Gene Nutriente.

1994 - 1998 Doutorado em Nutrição (Conceito CAPES 5).

Universidade Federal de São Paulo, UNIFESP, Brasi

Título: Influencia dos fatores dieteticos sobre a massa ossea de pacientes litiasicos, Ano de Obtenção: 1998.

Orientador: (9) Profa Dra Ita Pfeferman Heilberg.

Bolsista do(a): Coordenação de Aperfeiçoamento de Pessoal de Nivel Superior ,CAPES ,Brasil

Palavras-chave: dieta; densidade mineral ossea; litiase renal; hipercalciuria.

Grande área: Ciências da Saúde / Área: Nutrição / Subárea: Bioquimica da Nutrição

Setores de atividade: Cuidado A Saúde das Pessoas.

1991 - 1993 Mestrado em Nutrição (Conceito CAPES 5)

Universidade Federal de São Paulo, UNIFESP, Brasil.

Titulo: Avaliacao da ingestão de nutrientes litogenicos em pacientes litiasicos. Ano de Obtenção: 1993

Orientador: (6) Prof Dr. Nestor Schor

Bolsista do(a): Fundação de Amparo à Pesquisa do Estado de São Paulo ,FAPESP ,Brasil .

Palavras-chave: dieta; litiase renal.

Grande área: Ciências da Saúde / Área: Nutrição / Subárea: Análise Nutricional de População.

Setores de atividade: Nutrição e Alimentação.

1985 - 1989 Graduação em Nutricao

Centro Universitário São Camilo - Campus Pompeia, SAO CAMILO, Brasil.

\section{Atuação profissional}

\section{Universidade de São Paulo, USP, Brasil.}

Vinculo institucional

2001 - Atual Vínculo: Professor, Enquadramento Funcional: Professor doutor, Carga horária: 40, Regime: Dedicação exclusiva. 


\section{Karin Sedó Sarkis}

Nutricionista. Doutoranda em Nutrição em Saúde Pública pela Faculdade de Saúde Pública USP. Mestre em Saúde Pública, área de concentração Nutrição, pela Faculdade de Saúde Pública - USP. Nutricionista colaboradora do Ambulatório de Nutrição da Disciplina de Reumatologia - UNIFESP. Integrante da equipe do Check-up do Grupo Fleury Medicina e Saúde. Autora do livro Alimentação Saudável: a sua importância na qualidade de vida e na prevenção de doenças.

prevenção de doenças.
(Texto informado pelo autor)

Ulttima atualização do currículo em 27/02/2012

Endereço para acessar este CV:

http//lattes cnpq br/9557672832700210

Certificado

pelo auter en

$27 / 02 / 12$

\begin{tabular}{|r|}
\hline Dados pessoais \\
Nome Karin Sedó Sarkis \\
$\begin{array}{r}\text { Nome em citações } \\
\text { bibliográficas }\end{array}$ \\
Sexo \\
Semis, K. S. \\
\hline
\end{tabular}

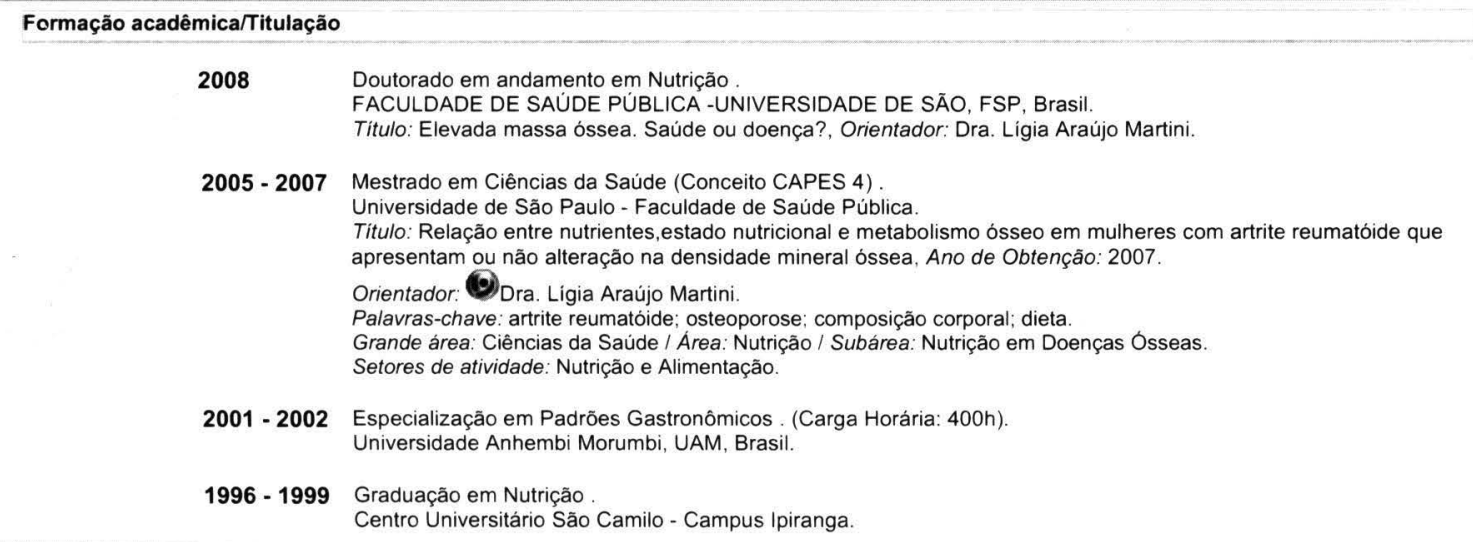

Formação complementar

2009 - 2009 Aconselhamento em Alimentação Complementar. (Carga horária: 20h). SECRETARIA DE ESTADO DA SAUDE.

2005 - 2005 IV Curso de Avanços e Tratamento da Osteoporose. (Carga horária: 10h) Centro de Estudos em Doenças Ósteo-Metabólicas.

2005 - 2005 IX Curso Introdutório à Liga de Geriatria. (Carga horária: 15h) Fundação Faculdade de Medicina.

2005 - 2005 Aperfeiçoamento ao Ensino. (Carga horária: 144h). Faculdade de Saúde Pública - USP

2004-2004 VII Curso Anual de Nefrologia. (Carga horária: 34h). Fundação Faculdade de Medicina.

1999 - 1999 Aleitamento Materno. (Carga horária: 16h). Hospital do Servidor Público Estadual.

1998 - 1998 Treinamento de Equipes Multiprof. em Amamentação. (Carga horária: 30h). Faculdade de Ciências Médicas de Santos.

\section{Atuação profissional}

Universidade Nove de Julho, UNINOVE, Brasil.

Vinculo institucional

2011 - 2011 Vínculo: Professor Visitante, Enquadramento Funcional: Professor visitante (pós-graduação), Carga horária: 4

Outras informações Disciplina ministrada: Nutrição Clínica nos Diversos Ciclos da Vida do curso de Pós-graduação em Nutrição Clinica 